\title{
Demonstration of ElectroChemical Remediation Technologies-Induced Complexation
}

\section{Final Report}

October 1, 2001 to December 15, 2002

Dr. Barry L. Burks

December 2002

DE-AC26-01NT41346

Submitted by:

TPG Applied Technology

10330 Technology Drive

Knoxville, TN 37932
Weiss Associates 5801 Christie Avenue

Emeryville, CA 94608
ADA Technologies 8100 Shaffer Parkway Littleton, CO 80127-4107 


\section{Disclaimer}

This report was prepared as an account of work sponsored by an agency of the United States Government. Neither the United States Government nor any agency thereof, nor any of their employees, makes any warranty, express or implied, or assumes any legal liability or responsibility for the accuracy, completeness, or usefulness of any information, apparatus, product, or process disclosed, or represents that its use would not infringe privately owned rights. Reference herein to any specific commercial product, process, or service by trade name, trademark, manufacturer, or otherwise does not necessarily constitute or imply its endorsement, recommendation, or favoring by the United States Government or any agency thereof. The views and opinions of authors expressed herein do not necessarily state or reflect those of the United States Government or any agency thereof. 


\section{Abstract}

The Project Team is submitting this Final Report on the results of its bench-scale demonstration of ElectroChemical Remediation Technologies (ECRTs) and in particular the Induced Complexation (ECRTs-IC) process for remediation of mercury contaminated soils at DOE Complex sites. ECRTs is an innovative, in-situ, geophysically based soil remediation technology with over 50 successful commercial site applications involving remediation of over two million metric tons of contaminated soils. ECRTs-IC has been successfully used to remediate $220 \mathrm{cu}$ m of mercury-contaminated sediments in the Union Canal, Scotland. In that operation, ECRTs-IC reduced sediment total mercury levels from an average of $243 \mathrm{mg} / \mathrm{kg}$ to 6 $\mathrm{mg} / \mathrm{kg}$ in 26 days of operation. The clean up objective was to achieve an average total mercury level in the sediment of $20 \mathrm{mg} / \mathrm{kg}$.

\section{Project Objectives}

The bench-scale phase of this project demonstrated the ECRTs-IC technology in a large volume (approximately $150 \mathrm{~L}$ ) laboratory test with mercury contaminated soils from the Y-12 National Security Complex. The overall objective of the Team was to demonstrate a cost-effective alternative to the identified baseline technology of soil extraction, hauling, low temperature thermal desorption (retorting), and disposal of treated soil. The specific objective of the benchscale test was to show the utility of ECRTs through laboratory testing. The success criteria for this Phase I ECRTs testing established with the National Energy Technology Laboratory (NETL) and the Y-12 National Security Complex (Y-12) stakeholders were:

$>$ Mercury is mobilized to both anode and cathode.

$>$ Mercury is precipitated on one or both power electrodes.

$>$ ECRTs test cell demonstrates mercury reduction below the RFP defined level of $0.25 \mathrm{mg} / \mathrm{L}$ in the TCLP leachate.

$>$ ECRTs test cell mercury mobilization rate meets or exceeds that for the EKAR test cell.

\section{Results}

The results of the bench-scale tests met all four of the objectives set prior to beginning work. Mercury in the soil in the test cell was mobilized and precipitated to both the cathode and the anode. The mercury level in the soil was reduced below the TCLP level of $0.25 \mathrm{mg} / \mathrm{L}$ and the mobilization rate achieved exceeded that for the simultaneous EKAR test.

\section{Conclusions}

Bench-scale tests offer the researcher an opportunity to demonstrate the validity of their concept and to learn how their concept will perform under given circumstances. The Demonstration of ElectroChemical Remediation Technologies accomplished both of these objectives. First, the bench-scale tests proved that ECRTs-IC works and that it works better than EKAR. Second and more important, the proof of process testing performed on the bench level demonstrates that ECRTs-IC is a significant new weapon in the environmental remediation industry's arsenal and is especially valid to the problems faced by the U.S. Department of Energy at its former weapons sites. 


\section{Table of Contents}

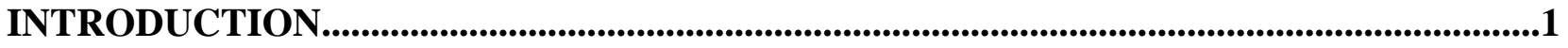

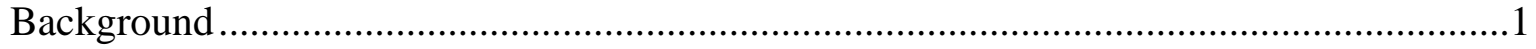

Purpose of Phase I....................................................................................................

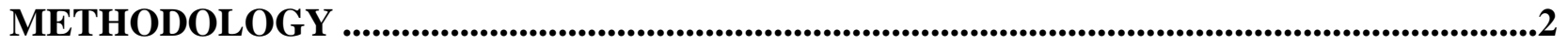

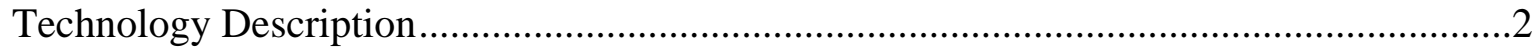

Approach To Solving Problem ..........................................................................................4

RESULTS AND DISCUSSION ...............................................................................................14

Description of Test Runs and Process or Parameter Changes ................................................14

Numerical \& Non-numeric Test Results................................................................................16

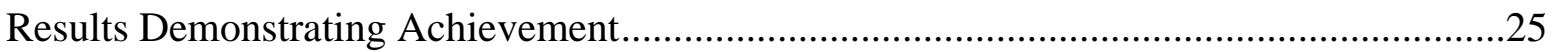

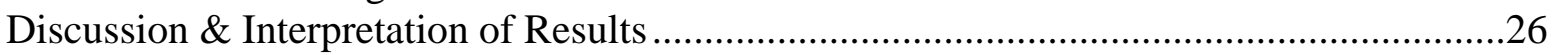

Unanticipated \& Unproductive Results ................................................................................30

ENVIRONMENT, SAFETY AND HEALTH CONSIDERATIONS..........................................31

Pre-demonstration Activities .........................................................................................

CONCLUSIONS AND RECOMMENDATIONS...................................................................33

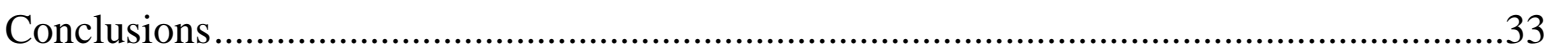

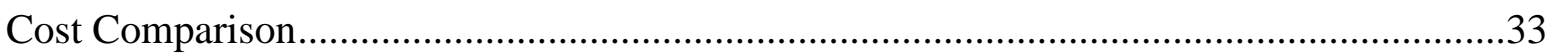

Regulatory \& Other Participant Acceptance........................................................................34

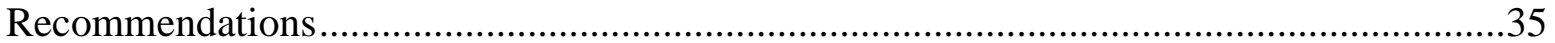

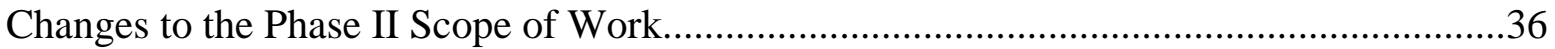

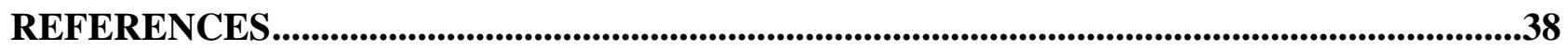

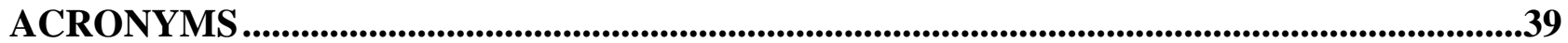

APPENDIX - WORK PLAN 


\section{$\underline{\text { List of Figures }}$}

Figure 1 Stabilization skid designed and built for mercury contaminated soils ...........................4

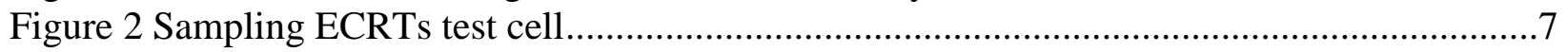

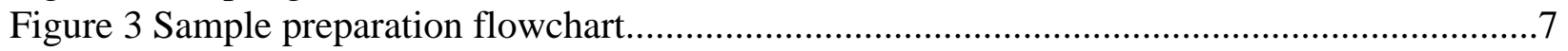

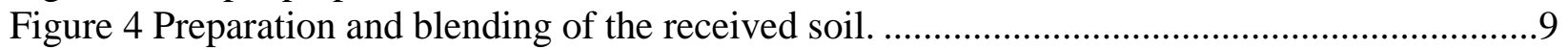

Figure 5 Schematic of ECRTs-IC test cell.....................................................................11

Figure 6 Steel cathode inside the ECRTs cell................................................................12

Figure 7 Filled ECRTs cell. Power supply and datalogger shown at left....................................12

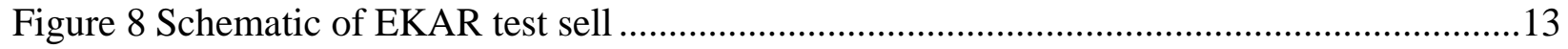

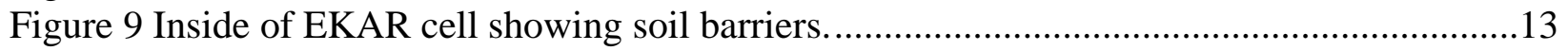

Figure 10 EKAR cell (showing pump, filter, and ion exchange columns) ................................13

Figure 11 Elemental mercury droplet on the surface of the ECRTs cathode ..............................15

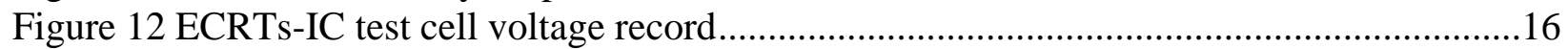

Figure 13 ECRTs-IC test cell current record .................................................................. 17

Figure 14 ECRTs test cell, total mercury profiles over time ................................................18

Figure 15 ECRTs-IC test cell pre- and post-test TCLP values.................................................19

Figure 16 EKAR test cell voltage record .......................................................................22

Figure 17 EKAR test cell current record ....................................................................22

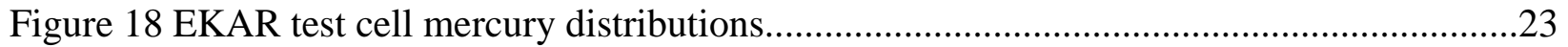

Figure 19 ECRTs test cell pre- and post-test TCLP values .................................................24

\section{$\underline{\text { List of Tables }}$}

Table 1. Analytical scheme for speciated mercury ..........................................................6

Table 2 Mercury analysis of random samples from soil blending ............................................8

Table 3 Mass of soil and water loading into the two test cells. ...............................................10

Table 4 Summary of primary sampling events .............................................................14

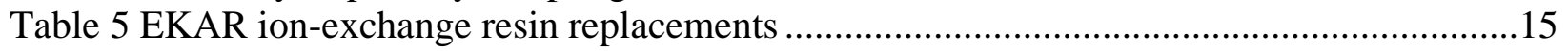

Table 6 ECRTs-IC test cell mass balance.........................................................................20

Table 7 Summary of ECRTs-IC test results ........................................................................20

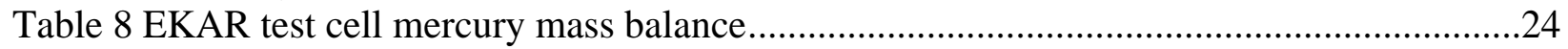

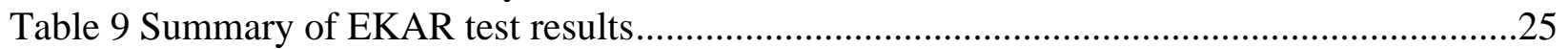

Table 10 Comparison of ECRTs-IC and EKAR performance measures....................................26

Table 11 Luebeck-Herrenwyk container test results .........................................................28

Table 12 Hamburg Port sludge results.............................................................................29

Table 13 Finnow Rolling Mill wastewater settling lagoon....................................................29

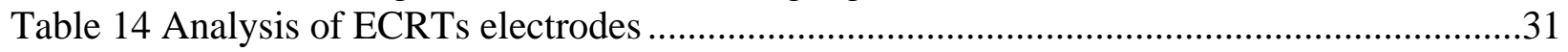

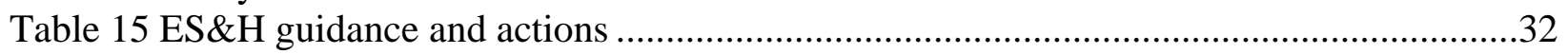

Table 16 ECRTs-IC and low-temperature thermal desorption cost benefit analysis....................34

Table 17 ECRTs project activity and participating regulatory agencies identified......................35 


\section{Introduction}

\section{Background}

After nearly sixty years of designing, manufacturing, and testing nuclear weapons, the U.S. Department of Energy (DOE) is faced with the challenge of cleaning up the hazardous waste left behind. More than 5,700 known DOE groundwater plumes have contaminated more than 475 billion gallons of water. DOE landfills contain more than 3 million cubic meters of buried waste, which could potentially contaminate the surrounding environment. At DOE sites throughout the country, soil, groundwater, and landfills containing or contaminated with hazardous and radioactive contaminants have special cleanup needs.

Mercury contamination is found at many DOE sites with the largest problems found at the Savannah River Site and the Oak Ridge, Tenn., Y-12 National Security Complex (Y-12). Mercury was utilized during the 1950s and early 1960s to separate lithium isotopes for the manufacture of nuclear weapons. At Y-12 remedial actions are planned that include excavation and disposal of 300,000 cubic yards of soil and sediment contaminated with mercury, other heavy metals, and radionuclides (primarily uranium). It is currently estimated that up to 50,000 cubic yards (CY) will be classified as Resource Conservation and Recovery Act (RCRA) waste due to the presence of mercury and other heavy metals.

The Team was selected by DOE's National Energy Technology Laboratory to conduct a focused evaluation of the ElectroChemical Remediation Technologies-Induced Complexation (ECRTsIC) ability to address these problems of soil and sediments contaminated with mercury and other metals, along with uranium and other radionuclides. ECRTs potentially offers DOE and industrial clients an in situ method to remove these contaminants from the environment without the addition of chemical treatments or extensive excavation. Applicable in virtually all settings, ECRTs would provide the greatest cost-benefit in applications involving sensitive eco-systems or contamination under buildings. In these situations, applying ECRTs would eliminate the necessity to destroy the building or the natural area just to gain access and remove the contamination.

Many such settings exist within the DOE complex. For example, the Oak Ridge Reservation (ORR) is divided into watersheds where multiple waste disposal and release sites are combined into characterization areas (CA). The Upper East Fork of Poplar Creek (UEFPC) CA contains the developed Y-12 plant industrial areas. The plant encompasses about 324 hectares and was built in 1943 as part of the Manhattan Project to produce components for various nuclear weapons systems. At Y-12, releases of mercury occurred with an estimated two million pounds of mercury lost to soils and surface waters. These losses have created a significant mercury contamination issue at the site with contamination residing in soil, sediment, surface water, groundwater, buildings, drains, and sumps. Mercury continues to be released from Y-12 from both point and non-point sources. Mercury enters UEFPC from direct erosion of contaminated soil, migration of dissolved mercury through storm drains and several outfalls, and through shallow groundwater. Several areas act as source terms due to very high concentrations of mercury being present. These include: the WEMA (under and around Bldgs. 9201-4, 9204-4, and $9201-5)$ ( $\leq 391 \mathrm{mg} / \mathrm{kg})$, Lake Reality ( $\leq 424 \mathrm{mg} / \mathrm{kg})$, and UEFPC streambed $(\leq 254 \mathrm{mg} / \mathrm{kg})$. 
Both Lake Reality and the UEFPC streambed are undisturbed natural areas supporting ecosystems characteristic of local aquatic habitats. Traditional remediation methods would involve the destruction of those habitats after going through the extensive environmental review process required under the National Environmental Policy Act, made problematic by the fact that areas such as these often serve as habitat for endangered or threatened species. ECRTs offers an alternative that does not necessitate destroying everything as the first step to reclaiming and remediating these areas.

\section{Purpose of Phase I}

NETL awarded the Team a contract to demonstrate ECRTs technology on mercury contaminated soils using a two-phase approach, including a bench-scale demonstration followed by a field demonstration. The objective of the Phase I bench-scale demonstration was to treat a selected soil sample and show that ECRTs-IC could meet pre-determined treatment goals. The Team proposed to test and demonstrate this patented technology for in-situ treatment of soils along with patent-pending technology for stabilization of mercury treatment residuals and wastewater contaminated with mercury. For in-situ technologies, the treatment goals were:

- Soil less than the Toxicity Characteristic Leaching Procedure (TCLP) level for mercury (0.2 mg/L in TCLP leachate)

- Ten times the Universal Treatment Standard $(0.25 \mathrm{mg} / \mathrm{L})$ in TCLP leachate

The treatment process was evaluated in bench-scale tests conducted in Golden, Colo. Phase I used large volume (roughly $150 \mathrm{~L}$ ) bench scale tests to validate the use of ECRTs-IC and benchmarked that performance against traditional electrokinetic remediation (EKAR) technology. The scope of work was broken down into four basic tasks: coordination and planning, bench-scale test work plan development, bench-scale testing, and reporting. After gaining the approval for Phase II of the program, a pilot scale demonstration of the technology will be performed at a site chosen by the DOE in Oak Ridge, Tenn.

ECRTs-IC has been successfully demonstrated in the field for remediation of mercury and metallic contaminated soils and sludges. However, it has not been successfully demonstrated on the bench scale, primarily because of scaling and system (electrical) resistance problems. The ECRTs-IC mechanism is operable only at low system resistance, low voltage gradients, and low current densities. This can be readily achieved in field operations but is generally very difficult to achieve in the laboratory. To account for the inefficiencies inherent in scaling down to the bench level, the Team planned to use a novel test cell design and test protocol.

\section{Methodology}

\section{Technology Description}

ElectroChemical Remediation Technologies

ECRTs-IC consists of two field-developed direct-current remediation technologies: (1) ECRTsElectroChemical GeoOxidation (ECRTs-ECGO) mineralizes organic contaminants to their inorganic components; and, (2) ECRTs-IC generates metal complexes and transports the metal complexes to the electrodes where the metals are deposited onto the electrodes. The NETL 
mercury remediation contract evaluated the use of ECRTs-IC for remediating mercurycontaminated soils.

The basic operation and theory of ECRTs is described in US and European Union Patents (Doering, 1994, 1996, 1997, and 1998). It can be summarized as follows:

$>$ A low-voltage/low-amperage, proprietary, coupled AC/DC electrical signal is sent through the soil or sediment (collectively referred to as soil) to be remediated in either in-situ or exsitu mode, via electrodes in the soil or sediment. This AC/DC signal generates a secondary polarization field within the soil opposing the primary inducing field.

$>$ This secondary polarization field within the soil allows the soil to act as a capacitor, storing and releasing electrical energy.

$>$ The proprietary power supply alternately charges and discharges polarization sites within the soil at any and all interfaces with the soil-ground water contaminant system including, but not limited to, soil grain/water interfaces and pore throat constrictions.

$>$ When the polarization sites are discharging, electrons are provided to the soil causing reduction. When the polarization sites are charging, electrons are taken from the soil causing oxidation.

$>$ The charging and discharging process occurs at a very high frequency resulting in the electrolysis of water at the pore scale, which provides the free radicals to perform redox reactions in the matrix.

This capacitive response is similar to that of a lossy dielectric (von Hipple, 1954a, b). It was first observed in soils, sediments, and rocks by Schlumberger (1920) and later confirmed by Vacquier, et. al. (1957), Keller and Licastro (1959), Hill (1972), and Zonge and Wynn (1975).

The pore scale redox reactions enhance the breakdown of complex organic contaminant molecules into simpler daughter products, in the case of ECRTs-ECGO, and the formation of high (electrical) mobility complex inorganic ions, in the case of ECRTs-IC. The latter technology (ECRTs-IC) was utilized in the NETL contract to mobilize the mercury in the soil from Y-12 and transport it to both electrodes where mercury was deposited.

\section{Mercury Stabilization}

The implementation of the ECRTs-IC technology will generate mercury contaminated electrode components. These contaminated solids will require treatment and stabilization for safe disposal. One of the Team members developed and tested a process for stabilizing liquid elemental mercury and wastes containing greater than $260 \mathrm{mg} / \mathrm{kg}$ of mercury. In this patented process, mercury-containing waste is mixed with a combination of sulfur products in standard mixing equipment, producing a stable mercuric sulfide product. Other heavy metals such as barium, chromium, and lead also form insoluble sulfide compounds in the process. Treated wastes pass the mercury Universal Treatment Standard (UTS) of $0.025 \mathrm{mg} / \mathrm{L}$ based on the TCLP without the excessive use of treatment chemicals. Waste loadings are typically between 50 percent to 60 percent (wt/wt) for treated liquid elemental mercury wastes and greater than 80 percent (wt/wt) for mercury-containing solid wastes. 
The effectiveness of this process has been successfully demonstrated on radioactivecontaminated mercury wastes from several DOE national laboratory sites including liquid elemental mercury and soils with various mercury compounds. The process combines a proven mercury stabilization method with a scaleable, low-cost mixing technology. The technology has been licensed to Permafix Environmental Services (Kingston, Tenn.) and a stabilization unit is installed at their facilities in the East Tennessee Technology Park (Figure 1).

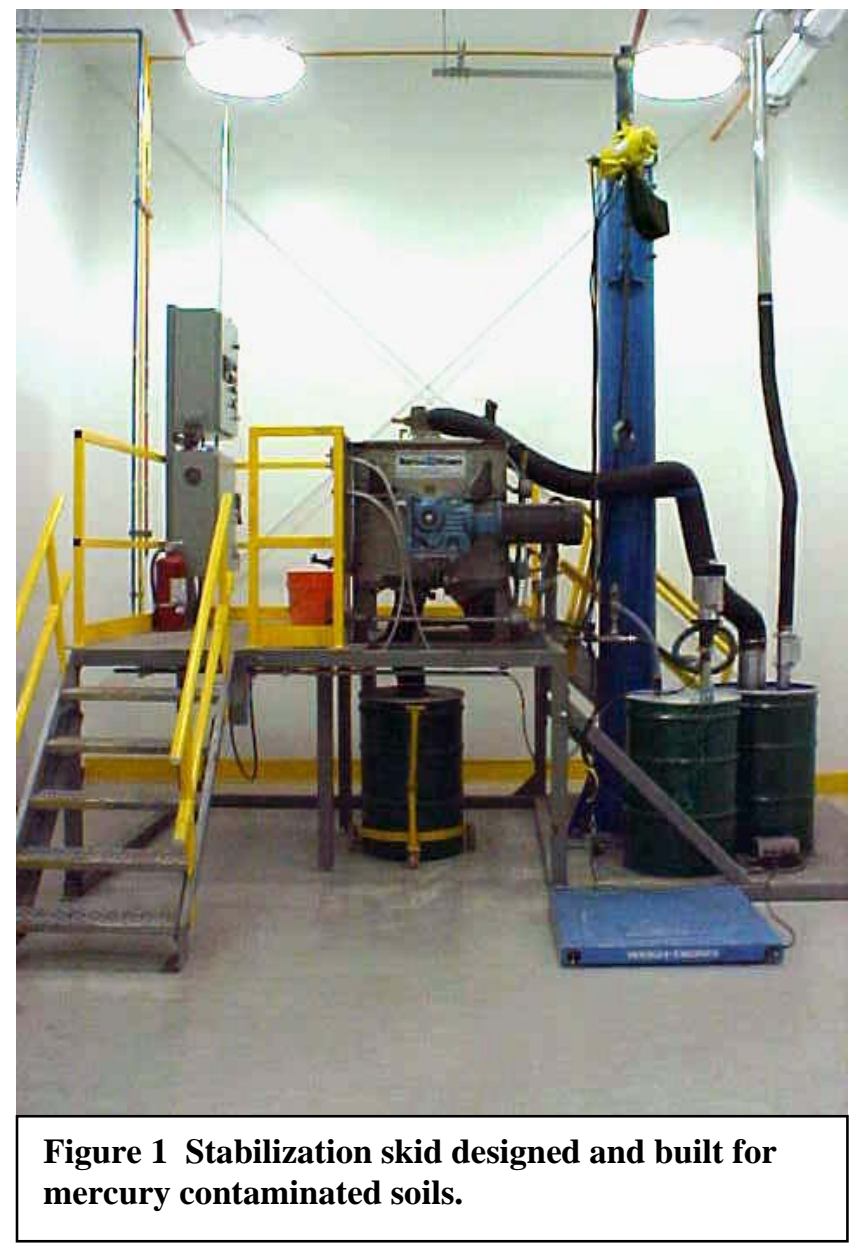

The method is also applicable to a wide range of commercial industries including mining, metal plating, and chlor-alkali plants. This process would also address cleanup of superfund sites having mercury contamination. The primary benefits of the process include the following:

- Stabilizes all chemical forms of mercury;

- Produces a waste that meets EPA's definition of an amalgam;

- Treated waste passes the mercury Universal Treatment Standard of $0.025 \mathrm{mg} / \mathrm{L}$ based on TCLP;

- Reagents react with other heavy metals to form insoluble sulfides;

- Mixed waste treated in this process can be disposed in a subtitle D landfill, substantially reducing disposal costs;

- Process is readily scaleable, using commercially available mixing equipment; and

- Process is economically viable.

Mercury and mercury-contaminated wastes are some of the more pervasive and troublesome wastes in the DOE waste inventory. Most of the larger DOE sites have radioactively contaminated liquid elemental mercury and solid wastes with more than 260-ppm mercury in their mixed waste inventories. Complex-wide, there are approximately $16.5 \mathrm{~m}^{3}(227,000 \mathrm{~kg})$ of elemental mercury in the legacy waste and approximately $0.2 \mathrm{~m}^{3}(2,600 \mathrm{~kg})$ are generated each year at the Savannah River Site. In addition, there are more than $50,000 \mathrm{~m}^{3}$ of mercury containing mixed low-level and transuranic wastes at 19 DOE sites.

\section{Approach To Solving Problem}

ElectroChemical Remediation Technologies

ECRTs was developed in response to the poor field performance of traditional electro-kinetic remediation. The ECRTs developer has successfully remediated over 2,000,000 metric tons of 
metals- and organics-contaminated soil at over 50 sites in Europe. Additionally, the ECRTs developer has completed two full-scale remediation projects in the U.S.

Two of the ECRTs-IC field case histories involved mercury contamination. One case history involved the successful mobilization and removal of over $76 \mathrm{~kg}$ of mostly mercury from $220 \mathrm{cu}$. $\mathrm{m}$. of clay/silt sediments in the Union Canal site, Scotland, contaminated with elemental and methyl mercury. Initial total mercury concentrations of 33-870 mg/kg dry mass (d.m.) were found, based on pre-remediation sampling within and outside of the test cell. The cleanup objective for this project was set at $20 \mathrm{mg} / \mathrm{kg}$. The initial average total mercury concentration of $243 \mathrm{mg} / \mathrm{kg}$ was reduced to an average of $6 \mathrm{mg} / \mathrm{kg}$ in just 26 days of ECRTs-IC operation based on concurrent- and post-remediation sampling within and outside of the test cell. A second case history involved removal of mercury amalgam contamination of sewage sludges containing dental amalgams at Montluçon, France. Total mercury concentrations of 15-54 mg/kg d.m. were reduced to $0.002-0.035 \mathrm{mg} / \mathrm{kg}$ d.m. in just seven days of ECRTs-IC operation.

ECRTs was developed in the field and, because of this and the system physics, it performs much better in full-scale field applications than in laboratory-scale applications. Previous attempts at bench-scale tests by the ECRTs developer have shown that laboratory work only qualitatively demonstrated their effectiveness. The laboratory data could not be used for quantitative scaling of the technologies to field conditions. For example, laboratory tests are not appropriate for predicting field operations costs and/or efficiencies. This inability to predict field performance in laboratory tests is due to problems in scaling down the technologies from field to laboratory scale and back up from laboratory results to field conditions.

For example, the ECRTs developer used a large-volume $(46.5 \mathrm{~cm}$ x $29 \mathrm{~cm}$ x $29 \mathrm{~cm})$ test cell to demonstrate ECRTs-IC removal of elemental mercury in contaminated soil from a Halle, Germany, chlor-alkaline chemical factory. Two electrodes were installed and the cathode was housed in a special well casing with vertical slots. Because the goal of this demonstration was only to show that $\mathrm{Hg}^{\circ}$ could be mobilized and removed, and not to completely remediate the soil, the test was run for only two hours and 10 minutes. After this short period of operation, the cathode was covered by a silvery coat, which could not be rubbed off. Analysis indicated that 30.2 g of mercury was deposited onto the cathode. The "well” tube was fully filled with sludge. When the well casing was removed from the soil box, $138 \mathrm{~g}$ of elemental mercury was recovered from the sludge. The anode showed high rates of corrosion.

The NETL Phase I work specified bench-scale tests. To address this request, the Team proposed conducting the tests in large volume (approximately $90 \mathrm{~cm}$ x $50 \mathrm{~cm}$ x $35 \mathrm{~cm}$ ) test cells, with 80 $\mathrm{cm} \times 32 \mathrm{~cm}$ electrodes (along the long side of the test cell), containing approximately $150 \mathrm{~L}$ of water-saturated mercury-contaminated soil. The test approach was to:

$>$ Screen out $>0.25$ in. debris from the Y-12 mercury contaminated soil ( $\mathrm{Y}-12$ soil).

$>$ Homogenize the contaminated $\mathrm{Y}-12$ soil.

$>$ Determine initial total mercury concentration in the homogenized Y-12 soil.

$>$ Load the test cell with approximately $150 \mathrm{~L}$ of the homogenized Y-12 soil and saturate it with local (Golden, Colo.) tap water. 
Sample the loaded test cell to determine the initial mercury concentrations for (a) watersoluble mercury via water leach, (b) TCLP mercury via acetic acid leach, (c) water soluble plus metallic mercury via nitric acid leach, and (d) total mercury via aqua regia leach.

$>$ Initiate ECRTs-IC operation, monitoring the current and voltage to the power electrodes.

$>$ Resample after an estimated appropriate period of ECRTs-IC operation to check for changes in mercury concentrations.

$>$ Extend the test for additional time based on the first sampling results and retest again.

$>$ Load a second test cell and run traditional EKAR simultaneously with the ECRTs-IC test as a benchmark.

The Phase I ECRTs testing would be considered successful if:

$>$ Mercury is mobilized to both anode and cathode.

$>$ Mercury is precipitated on one or both power electrodes.

$>$ ECRTs test cell demonstrates mercury reduction below the RFP defined level of $0.25 \mathrm{mg} / \mathrm{L}$ in the TCLP leachate.

$>$ ECRTs test cell mercury mobilization rate meets or exceeds that for the EKAR test cell.

Mercury Stabilization

The ability to stabilize the mercury deposited on the ECRTs-IC electrodes is critical to costeffective operation of the process. It was planned to use a patented mercury-bearing waste stabilization process (described above) to treat the electrodes at the end of the bench-scale testing. A simple process to stabilize the collected mercury as either an amalgam or mercury compound (such as mercuric sulfide) was planned, with a TCLP test on the stabilized residue to confirm sequestration of the mercury.

\section{Test Procedures Followed}

The mercury-contaminated soil from Y-12 was blended and loaded into two identical test cells. Soil samples were withdrawn at the start of the test period and at defined intervals during the test. These samples were analyzed for mercury, zinc, cadmium, copper, lead, silver, iron, arsenic, selenium, and uranium.

Additional emphasis was placed on mercury and three different extraction techniques were utilized to discern different mercury species (Table 1). The soil samples were also tested for conductivity, $\mathrm{pH}$, and major anions using ion chromatography. In addition to the analysis of the soils, the tap water used in the cells was analyzed for $\mathrm{pH}$, conductivity, total dissolved solids and anions.

Table 1. Analytical scheme for speciated mercury

\begin{tabular}{|c|c|}
\hline Extraction Method & Target Species \\
\hline Deionized Water & Soluble (oxidized) mercury \\
\hline Dilute Nitric Acid & Elemental plus soluble mercury \\
\hline Aqua regia & Total mercury \\
\hline
\end{tabular}


At the beginning of the tests, after the soils and aqueous phases have been allowed to equilibrate but before the power is turned on, samples were collected from the two cells. The samples were collected using a sampling tube consisting of a $3 / 4$ " plastic pipe. The pipe was inserted to approximately the mid-level of the cell, the upper end was then sealed with a stopper, and the pipe and soil sample withdrawn (Figure 2). The soil samples were handled following the flowchart shown as Figure 3. This sampling procedure was repeated after a period thought to represent the mid-point of the test. The end-point for the testing was estimated on the basis of the comparison of initial and "mid-point" results, along with examination of the current versus time data. A similar soil sampling regimen was undertaken at test end.

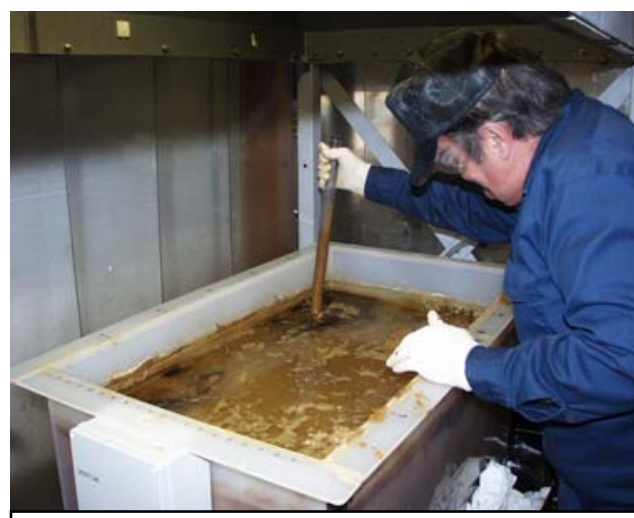

Figure 2 Sampling ECRTs test cell.
Mercury and other mobilized ions in the EKAR cell accumulated in external ion-exchange columns. The raw resin was analyzed prior to loading the cells and the entire contents of the ion-exchange cells were periodically replaced during the test period. At the conclusion of the tests, the samples of resin from each column were digested and analyzed for mercury.

At the conclusion of the test, the electrodes were rinsed of any soil material, dried, weighed, and thickness measured at the same locations used for the pre-test measurements. The electrodes were cut into sixteen approximately equalarea sections and each section weighed. Two widely separated sections of each electrode were digested in aqua regia and analyzed for total mercury. Two other widely separate sections were cut into smaller pieces $(<9.5 \mathrm{~mm})$ and analyzed by the TCLP procedure for extractable mercury.

The remaining twelve pieces will be separated into four groups of three for each electrode. The mercury on these sub-sets were to be stabilized using proprietary stabilization methods and tested using the TCLP procedure.

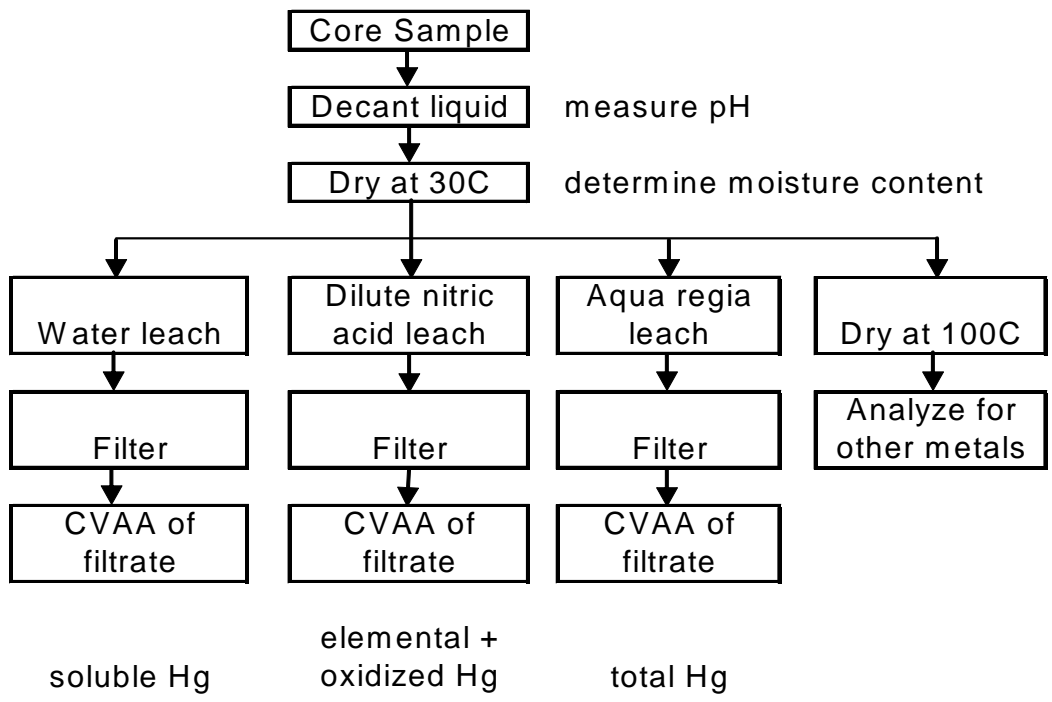

Figure 3 Sample preparation flowchart. 
QA/QC Procedures Followed

A Quality Assurance Project Plan (QAPP) was developed for Phase I utilizing the prime contractor Corporate QA Program Manual (Corporate QA Manual) as well as the quality assurance (QA) program requirements contained in the contract. The Team implemented its Corporate QA Program and the QAPP during the performance of this contract. If Phase II is implemented, the QAPP will be revised as appropriate.

The structure of the QAPP followed the prime contractor Corporate QA Plan to ensure that all elements were addressed. Although it was deemed appropriate that certain provisions of the Corporate QA Program warranted paraphrasing or repeating in the QAPP, all provisions contained in the Corporate QA Manual, including related QA requirements, fully applied to the ECRTs Project unless specific exception was taken. The Corporate QA Manual, though organized differently, is drawn directly from 10CFR830.120.

Demonstration Site Preparation, Equipment, \& Materials

Soil arrived from Oak Ridge in 22 five-gallon buckets, over packed in steel drums. The total mass of the soil was $926 \mathrm{~kg}$. Mercury vapor readings (Jerome Mercury Analyzer, Arizona Scientific) taken from inside the buckets averaged $0.024 \mathrm{mg} / \mathrm{m}^{3}$, with a high reading of 0.056 $\mathrm{mg} / \mathrm{m}^{3}$. No radioactivity was reported by Oak Ridge and none was detected in a sampling of the soil upon arrival. The soil was first sieved through a $1 / 4$ " screen. This process excluded $45 \mathrm{~kg}$, or approximately $12 \%$ of the total mass. The sieved soil was then blended in two separate batches using a 55-gallon poly drum on a drum roller. Blend A contained $182 \mathrm{~kg}$ and Blend B contained $189 \mathrm{~kg}$. Five samples were pulled from each blend and analyzed for total mercury. At this point it was determined that the total mass of soil ( $371 \mathrm{~kg}$ ) was likely to be insufficient to fill the two cells to the desired depth. Additional soil was requested from Oak Ridge and six more fivegallon buckets of soil were received. This additional soil was intentionally taken from areas believed to have high mercury contamination in an effort to increase the overall mercury concentration in the blended soil. The final mercury analysis data are shown in Table 2 and the re-blending process is depicted in Figure 4.

Table 2. Mercury analysis of random samples from soil blending.

\begin{tabular}{|l|c|c|c|}
\hline & $\mathbf{1}^{\text {st }}$ Blend A & $\mathbf{1}^{\text {st }}$ Blend B & Reblend \\
\hline Measured mercury & 47.3 & 41.7 & 294 \\
concentration & 45.8 & 37.9 & 232 \\
$\mathbf{( m g / k g ) ~}$ & 36.1 & 35.7 & 212 \\
& 34.6 & 35.9 & 286 \\
& 63.4 & 34.2 & 237 \\
\hline Average (mg/kg) & 45.4 & 37.1 & 252 \\
\hline Std. Deviation & 12 & 3 & 36 \\
\hline Total Mass (kg) & 182 & 189 & \\
\hline
\end{tabular}




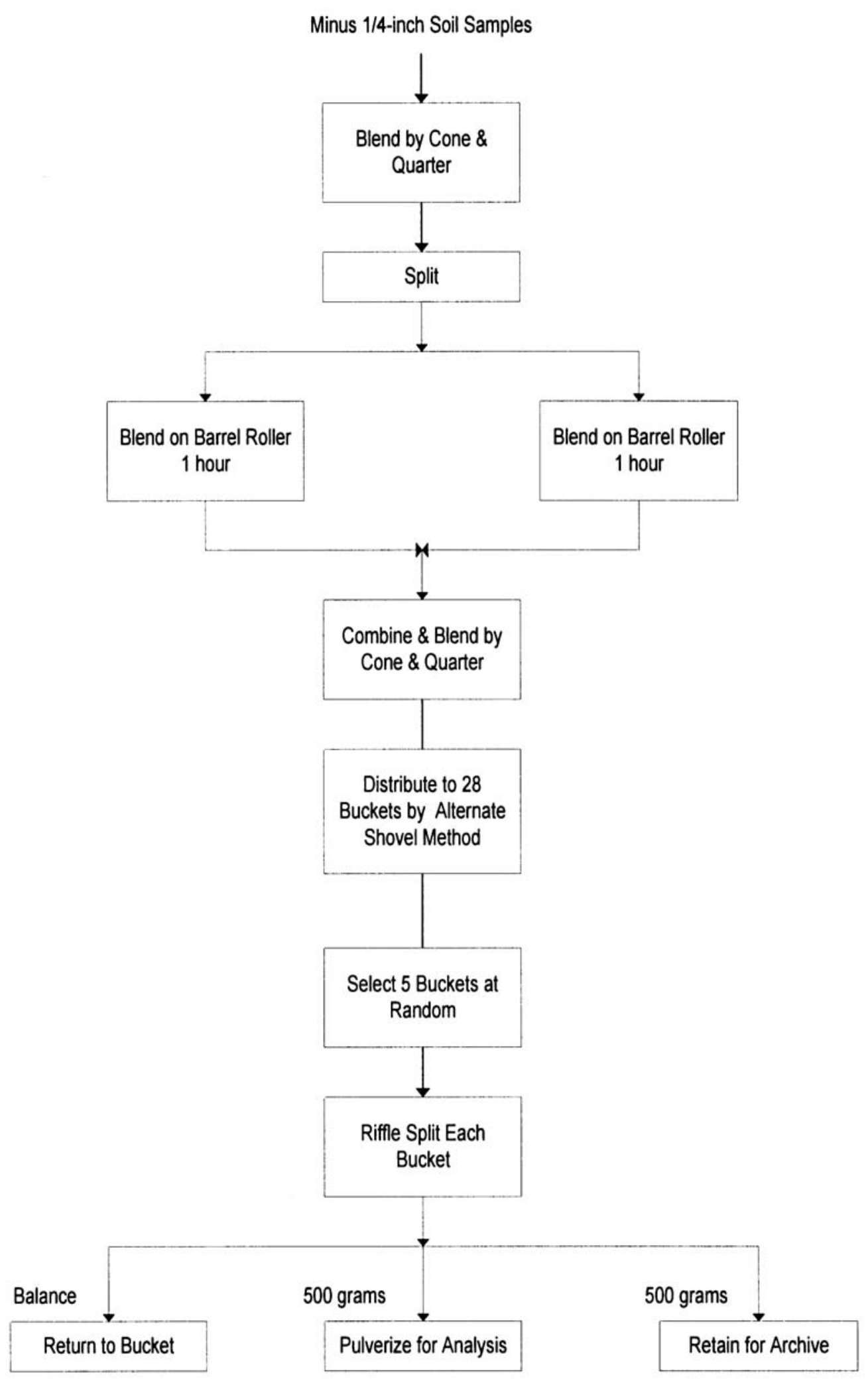

Figure 4 Preparation and blending of the received soil. 
The soil was next transferred to the two test cells, which were loaded by sequential addition of soil and water. The cell loading data are provided in Table 3.

Table 3. Mass of soil and water loading into the two test cells.

ECRT Cell Loading

\begin{tabular}{c|c|c|c|c}
\hline \multirow{2}{*}{$\begin{array}{c}\text { Bucket } \\
\text { No. }\end{array}$} & \multicolumn{3}{|c|}{ Weight, kg } & \% Water \\
\cline { 2 - 4 } & Soil & Water & Total & Added \\
\hline 8 & 13.73 & 3.755 & 17.48 & 27.35 \\
\hline 26 & 15.83 & 4.35 & 20.18 & 27.48 \\
\hline 9 & 17.26 & 4.75 & 22.01 & 27.52 \\
\hline 18 & 20.32 & 5.59 & 25.91 & 27.51 \\
\hline 31 & 16.08 & 4.42 & 20.50 & 27.49 \\
\hline 11 & 12.54 & 3.45 & 15.99 & 27.51 \\
\hline 30 & 17.83 & 4.9 & 22.73 & 27.48 \\
\hline 10 & 20.14 & 5.54 & 25.68 & 27.51 \\
\hline 25 & 17.85 & 4.91 & 22.76 & 27.51 \\
\hline 13 & 15.27 & 4.19 & 19.46 & 27.44 \\
\hline 7 & 16.83 & 4.63 & 21.46 & 27.51 \\
\hline 32 & 16.01 & 4.4 & 20.41 & 27.48 \\
\hline 14 & 16.01 & 4.4 & 20.41 & 27.48 \\
\hline 23 & 9.28 & 2.55 & 11.83 & 27.48 \\
\hline & & & & \\
\hline Total & 224.98 & 61.835 & 286.81 & 27.48 \\
\hline Water Fill & & 19.08 & & \\
\hline & & & & \\
\hline
\end{tabular}

EKAR Cell Loading

\begin{tabular}{c|c|c|c|c}
\hline \multirow{2}{*}{$\begin{array}{c}\text { Bucket } \\
\text { No. }\end{array}$} & \multicolumn{3}{|c|}{ Weight, kg } & \% Water \\
\cline { 2 - 4 } & Soil & Water & Total & \\
\hline 21 & 15.69 & 4.31 & 20.00 & 27.47 \\
\hline 6 & 17.10 & 4.70 & 21.80 & 27.49 \\
\hline 24 & 15.04 & 4.14 & 19.18 & 27.53 \\
\hline 20 & 20.01 & 5.53 & 25.54 & 27.64 \\
\hline 12 & 15.10 & 4.15 & 19.25 & 27.48 \\
\hline 16 & 15.51 & 4.27 & 19.78 & 27.53 \\
\hline 5 & 14.56 & 4.00 & 18.56 & 27.47 \\
\hline 29 & 15.40 & 4.23 & 19.63 & 27.47 \\
\hline 34 & 16.74 & 4.60 & 21.34 & 27.48 \\
\hline 22 & 16.31 & 4.48 & 20.79 & 27.47 \\
\hline 15 & 13.81 & 3.80 & 17.61 & 27.52 \\
\hline 33 & 21.75 & 5.98 & 27.73 & 27.49 \\
\hline & & & & \\
\hline & & & & \\
\hline & & & & \\
\hline Total & 197.02 & 54.19 & 251.21 & 27.50 \\
\hline Water Fill & & 41.34 & & \\
\hline & & & & \\
\hline
\end{tabular}

Both test cells used 62-gallon polypropylene tanks measuring 36Lx20Wx20D inches, (91x51x51cm, US Plastic Corp., Lima, Ohio). The layout of the ECRTs cell is shown in Figure 5. The test cells held two electrodes, each with a surface area of approximately $2,560 \mathrm{~cm}^{2}$. A sheet of UCAR graphite (grade CS158) approximately $0.9 \mathrm{~cm}$ thick is used as the ECRTs anode and a sheet of 20-gauge carbon steel acted as the cathode. The electrodes were supported by plastic holders made of arched sections of PVC pipe. The holders were made by cutting 2" PVC pipe in half and cutting a groove into the top of the arch-shaped piece of a thickness to match the electrode. The spacers were approximately 5-cm wide holding the electrodes about $2.5 \mathrm{~cm}$ from the cell wall (Figure 6).

A polypropylene lid prevented excessive evaporation from the cell. This lid was initially wired with a kill-switch to disconnect power to the cell's power supply whenever the lid was removed. Once testing began, the low voltage being used made this safety feature unnecessary and approval was obtained to disconnect the kill switch in order to prevent needless on/off cycling of the power supply.

The ECRTs test was powered by a custom AC/DC converter (110 VAC input, adjustable $\approx 170$ VDC max, 5 A output). The electrodes were connected to the power supply by insulated 10-12 gauge copper wire. The leads were attached to the electrodes using stainless steel nuts, bolts, and washers at the cathode and nylon nuts, bolts, and washers at the anode. 


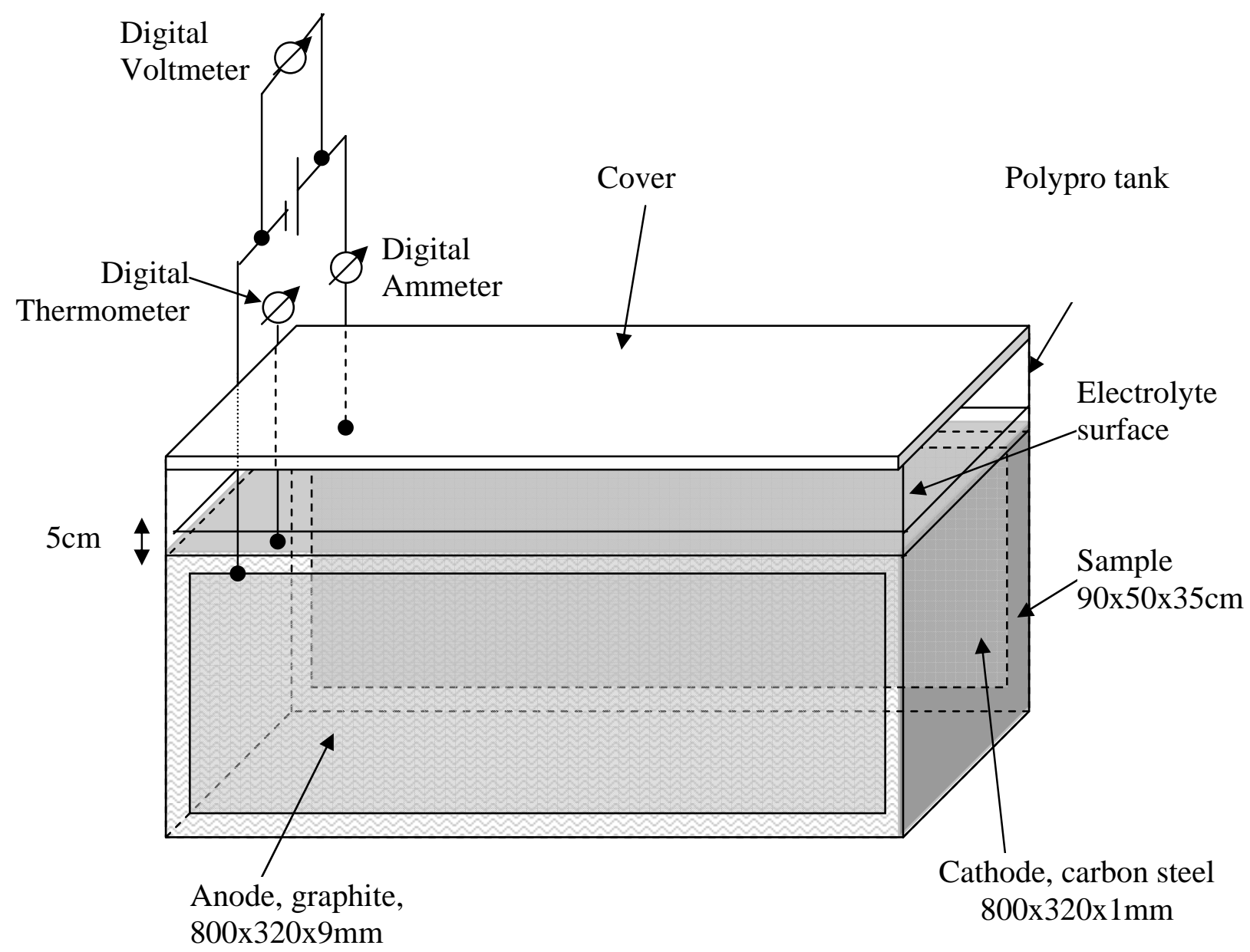

Figure 5 Schematic of ECRTs-IC test cell.

The DC power was routed through a signal conditioner and Campbell data logger. This configuration allowed for automated recording of voltage, amperage, and cell temperature (via a type-K thermocouple in the cell). The logger took readings every second and recorded fiveminute average values. The logger was connected to a phone modem to allow remote access of the recorded data.

The EKAR test cell (Figures 8,9, and 10) was identical to the ECRTs test cell, with the following exceptions:

The DC power supply was a commercially available unit (Sorensen Model DHP60022M2M9D) featuring 480 VAC input and a minimum 0 - 170 VDC, $0-5$ A DC output.

$>$ Both of the EKAR power electrodes were constructed from 20-gauge, 316L stainless steel.

$>$ The power electrodes were isolated from direct contact with the soil by a barrier constructed from a semi-permeable membrane supported by a 1/8”-thick perforated-PVC sheet.

$>$ The water in the electrode enclosures was circulated through external ion-exchange beds. The purpose of the semi-permeable membranes was to prevent solids from fouling the ion exchange columns. The water was pumped out from the cathode section, through a 5-micron 
filter, through cation and anion exchange resins (Model D8901, Barnstead/Thermolyne, Dubuque, IA), and returned at the anode section. A 36-rpm dualhead peristaltic pump provided a flow rate of approximately $250 \mathrm{cc} / \mathrm{min}$.
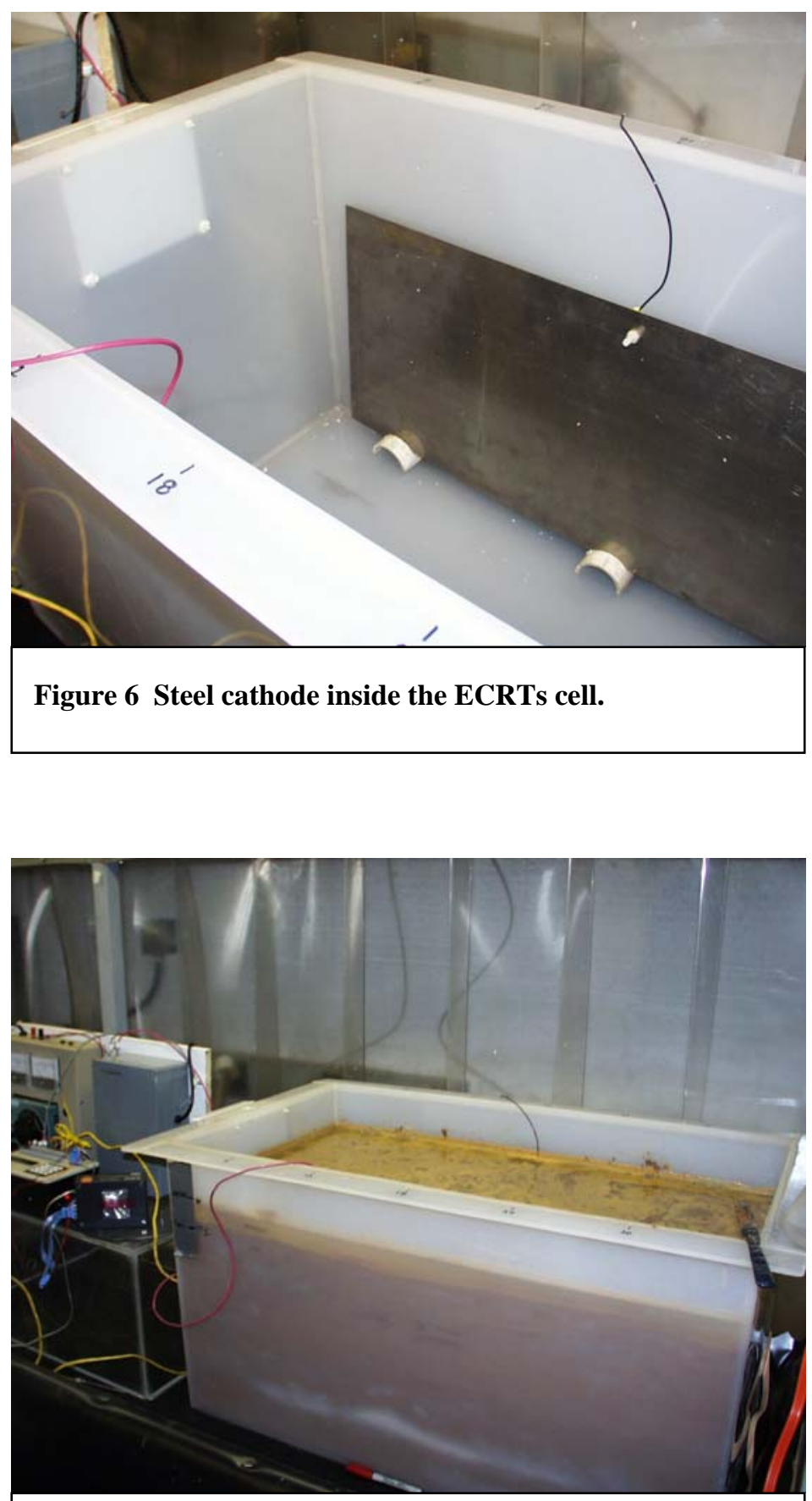

Figure 7 Filled ECRTs cell. Power supply and datalogger shown at left. 


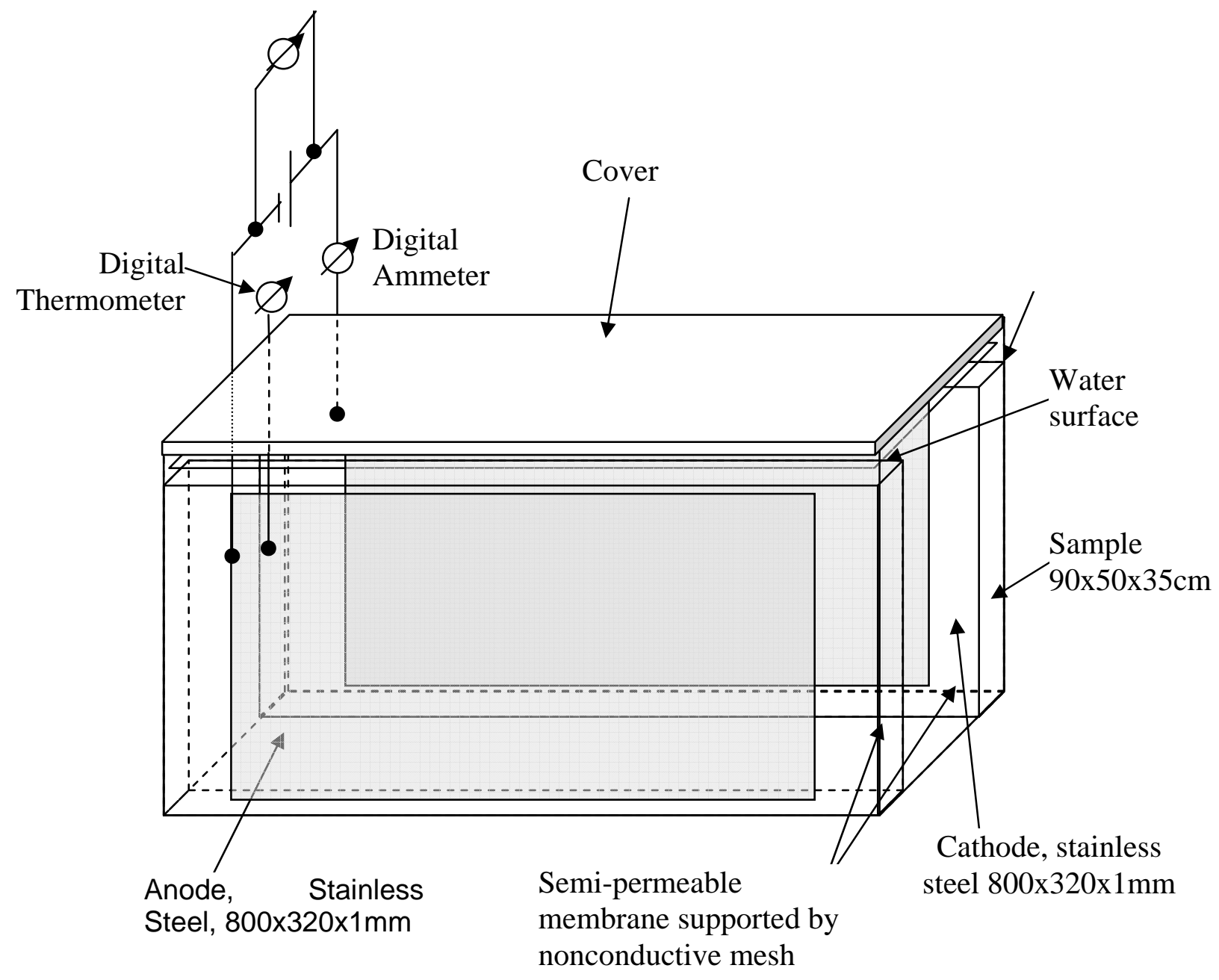

Figure 8 Schematic of EKAR test cell.
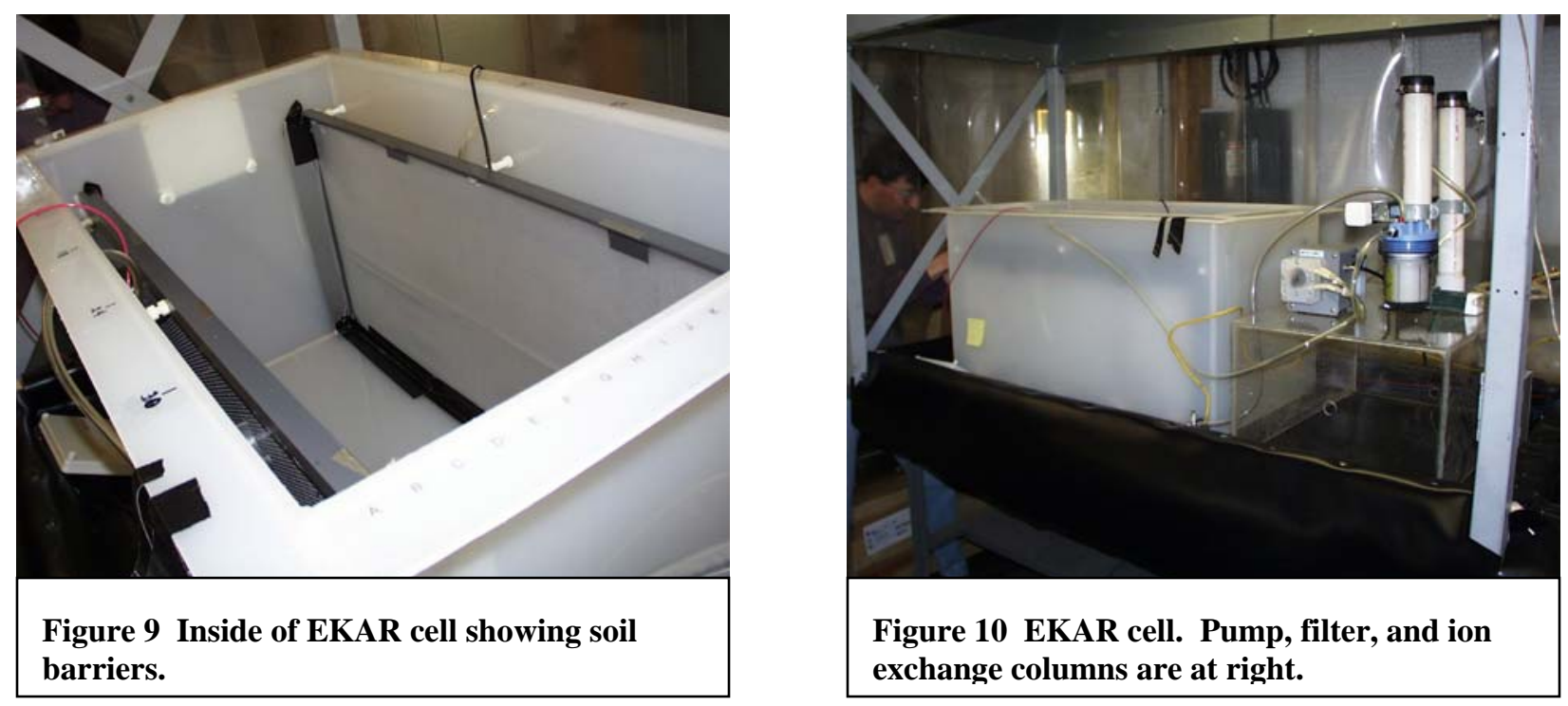
Other features of the EKAR cell, including the digital meters and the thermocouple were identical to those used in the ECRTs test cell. The "data out" terminals on the power supply provided a signal that could be read directly by the datalogger; therefore no signal conditioning was required for the EKAR power supply.

\section{Results and Discussion}

\section{Description of Test Runs and Process or Parameter Changes}

The two test cells were loaded with soil and the initial samples were withdrawn on February 6, 2002. On February 8, 2002, we replaced the original power source with another unit (Tenma Model 72-6180A). This power supply could supply up to 32 amps at 0 to 15 volts. Both test cells operated in the range of 12 VDC and 2 amps. Because of the relatively low voltage and current, the team requested that the kill-switches associated with each cell be disconnected. This change was requested in order to prevent on/off cycling the power supplies every time the cells were inspected. The modification was approved and the kill switches were disabled on February 8, 2002. Another set of soil samples were pulled on February 11, 2002 (Table 4).

Table 4. Summary of Primary Sampling Events.

\begin{tabular}{|c|c|c|c|c|}
\hline Date & Activity & Sample Locations & $\begin{array}{l}\text { Primary } \\
\text { Analysis }\end{array}$ & Comments \\
\hline 02/06/02 & Soil sample & $\begin{array}{l}\text { EKAR center point } \\
\text { ECRTs center point }\end{array}$ & Total Hg & Prior to start of power \\
\hline 02/11/02 & Soil sample & $\begin{array}{l}\text { EKAR transect ( } 5 \text { points }) \\
\text { ECRTs transect ( } 5 \text { points) }\end{array}$ & $\begin{array}{l}\text { Speciated Hg } \\
\text { Metals }\end{array}$ & \\
\hline 03/01/02 & Soil sample & $\begin{array}{l}\text { EKAR transect ( } 5 \text { points }) \\
\text { ECRTs transect ( } 5 \text { points) }\end{array}$ & Total Hg, Fe & $\begin{array}{l}\text { 2/11 sampling } \\
\text { showed other metals } \\
\text { to be below detection }\end{array}$ \\
\hline 03/15/02 & Soil sample & $\begin{array}{l}\text { EKAR transect ( } 5 \text { points }) \\
\text { ECRTs transect ( } 5 \text { points) }\end{array}$ & $\begin{array}{l}\text { Total Hg } \\
\text { TCLP Hg }\end{array}$ & Power off $3 / 14$ \\
\hline $04 / 04 / 02$ & Soil sample & $\begin{array}{l}\text { EKAR electrode ( } 3 \text { points) } \\
\text { ECRTs electrode ( } 3 \text { points) }\end{array}$ & Total Hg & $\begin{array}{l}3 \text { samples were } \\
\text { combined for analysis }\end{array}$ \\
\hline
\end{tabular}

The point where the copper wire attached to the ECRTs graphite anode was prone to corrosion, causing the power to the cell to be interrupted. The contact points on the EKAR cell were coated with silicone grease to protect them, but this was not done on the ECRTs cell. On February 22, 2002, the electrode contact on the ECRTs anode was mounted with a 6-inch long graphite extension to avoid corrosion of the contact wire. This extension piece raised the wire-to-graphite connection above the water level in the cell.

Operation of the test cells continued until March 13, 2002, for the ECRTs cell and March 14, 2002, for the EKAR cell. Total operating time for each cell was $741 \mathrm{hr}$. and $757 \mathrm{hr}$. for the ECRTs and EKAR respectively. Soil samples were collected on March 15, 2002, for analysis for 
total mercury and mercury via TCLP. The cells were then left at standby pending analysis of the March 15 soil samples.

On April 4, 2002, the electrodes were extracted from the test cells, washed, and shipped to the mercury stabilization subcontractor for analysis. Three soil samples were pulled from the vicinity of the electrodes prior to extraction. These samples were combined for analysis. The electrodes were rinsed with deionized water to remove clinging soil. The wash water and the soil washed from the electrodes was saved and analyzed for total mercury. The cells were emptied and the soil repacked for shipment back to Oak Ridge.

The EKAR ion-exchange columns had to be changed more frequently than expected, presumably due to the relatively high iron content of the soil. The exchange intervals are given in Table 5.

Table 5. EKAR ion-exchange resin replacements.

\begin{tabular}{|clcc|}
\hline Date & Activity & Remove & Install \\
\hline & installed first resin columns. Each resin placed in 2" PVC pipe with & & \\
05-Feb-02 & $\sim$ 13" bed. Flow runs from cathode - filter - anion - cation - to anode & & \\
\hline 07-Feb-02 & replaced prefilter & & \\
\hline 08-Feb-02 & replaced prefilter & \\
\hline & & & \\
11-Feb-02 & replaced prefilter and resin columns. Same set up 2/5 installation & AA-1, AC-1 & AA-2, AC-2 \\
\hline & Replaced prefilter and resin. New set up is direct installation of & & \\
15-Feb-02 & Barnstead Model D8901 two-stage IX column. & AA-2, AC-2 & D1 \\
\hline 26-Feb-02 & replaced prefilter and IX column with new D8901 & D1 & D2 \\
\hline 04-Mar-02 & replaced IX column with new D8901 & D2 & D3 \\
\hline 12-Mar-02 & replaced IX column with new D8901 & D3 & D4 \\
\hline 14-Mar-02 & Power shut off at 14:40 & & \\
\hline
\end{tabular}

After removal from the cells and rinsing, the electrodes were measured for thickness at eight points, weighed, and sectioned for further analysis. Each section was placed in a polyethylene bag for holding. Mercury vapor measurements taken within each bag suggested that the mercury

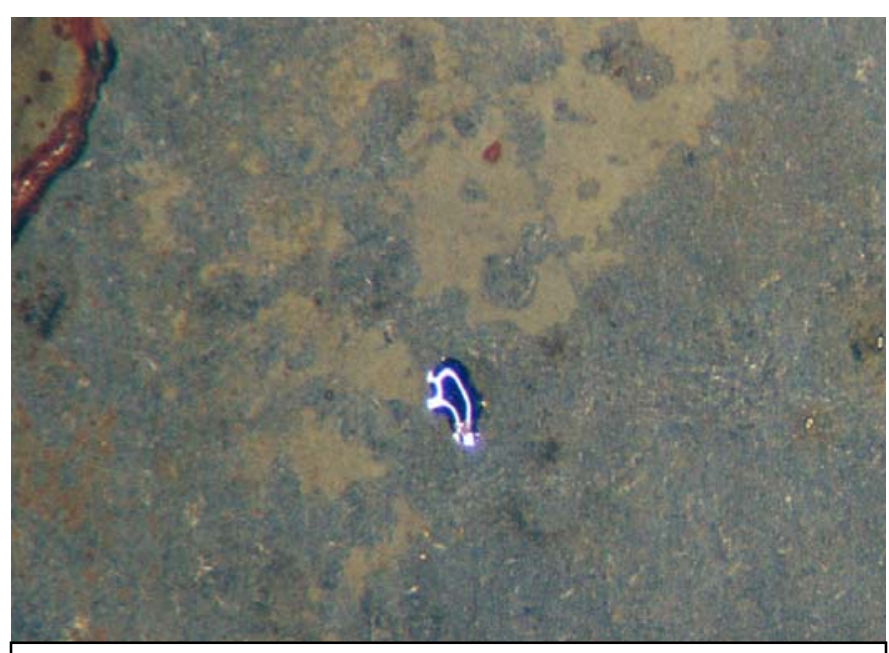
was not evenly distributed across the electrode, that is, some sections recorded high mercury readings, while others recorded none. Examination of the electrodes under a microscope revealed beads on mercury on the ECRTs cathode (Figure 11). No identifiable elemental mercury was seen at the anode; however, digestion and analysis of the anode indicated that mercury was present. All the mercury data were used to calculate a mercury mass balance for the two cells.

Figure 11 Elemental mercury droplet on the surface of the ECRTs cathode. 


\section{Numerical \& Non-numeric Test Results}

The ECRTs-IC test ran from February 6, 2002 to March 14, 2002. Correcting for system down time, the ECRTs-IC Test Cell was operational for a total of 741 hours. The power supply was run under constant voltage conditions.

The Team had requested information from NETL on the resistivity of the Y-12 soil prior to planning the laboratory tests. Because these soil resistivities were not available, the Team had to design the laboratory tests and specify equipment based on past experience, the NETL RFP, and prior Bechtel Jacobs Company Y-12 briefings. The Team expected (see above) contaminated Y12 soil with electrical resistivities of approximately $65 \mathrm{ohm}-\mathrm{m}$. High (1.2\% by weight) iron content in the Y-12 soil greatly reduced the soil electrical resistivities to about 3.8 ohms-m. This low resistivity soil forced a change in the power supply design from a high voltage/low current unit to one that could supply higher current, but only at a lower operating voltage.

The conductive soil also forced the test cell system to operate out of the optimal NETL testdesigned ECRTs-IC current/voltage operating range, because the test equipment planned by the Team was designed for a higher resistivity soil. This departure from optimum voltage and current conditions for the ECRTs-IC is one example of the difficulties in scaling the technology down from field operations to bench scale operations. During a field remediation project, a resistivity survey is among the first steps taken in the project. We fully expect to be able to optimize the ECRTs-IC system in the field relative to the subsurface resistivity structure.

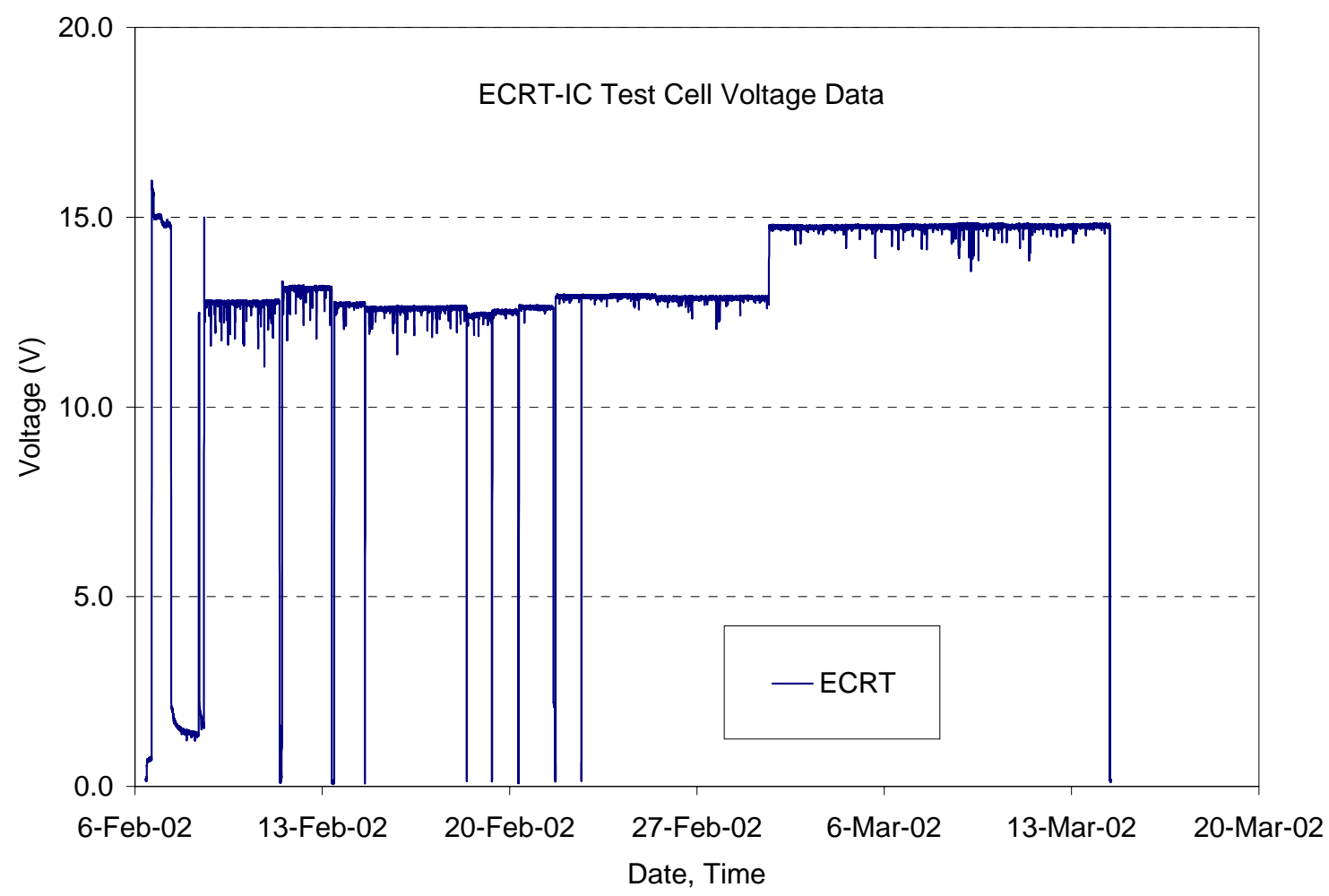

Figure 12 ECRTs-IC test cell voltage record. 
Figure 12 shows the ECRTs-IC Test Cell voltage as a function of time. The power supply voltage was periodically adjusted to compensate for changes in the test cell resistance due to, most likely, electrochemical changes in the soil during the test.

Figure 13 shows the ECRTs-IC Test Cell current as a function of time. As in Figure 12, the power supply voltage was periodically adjusted.

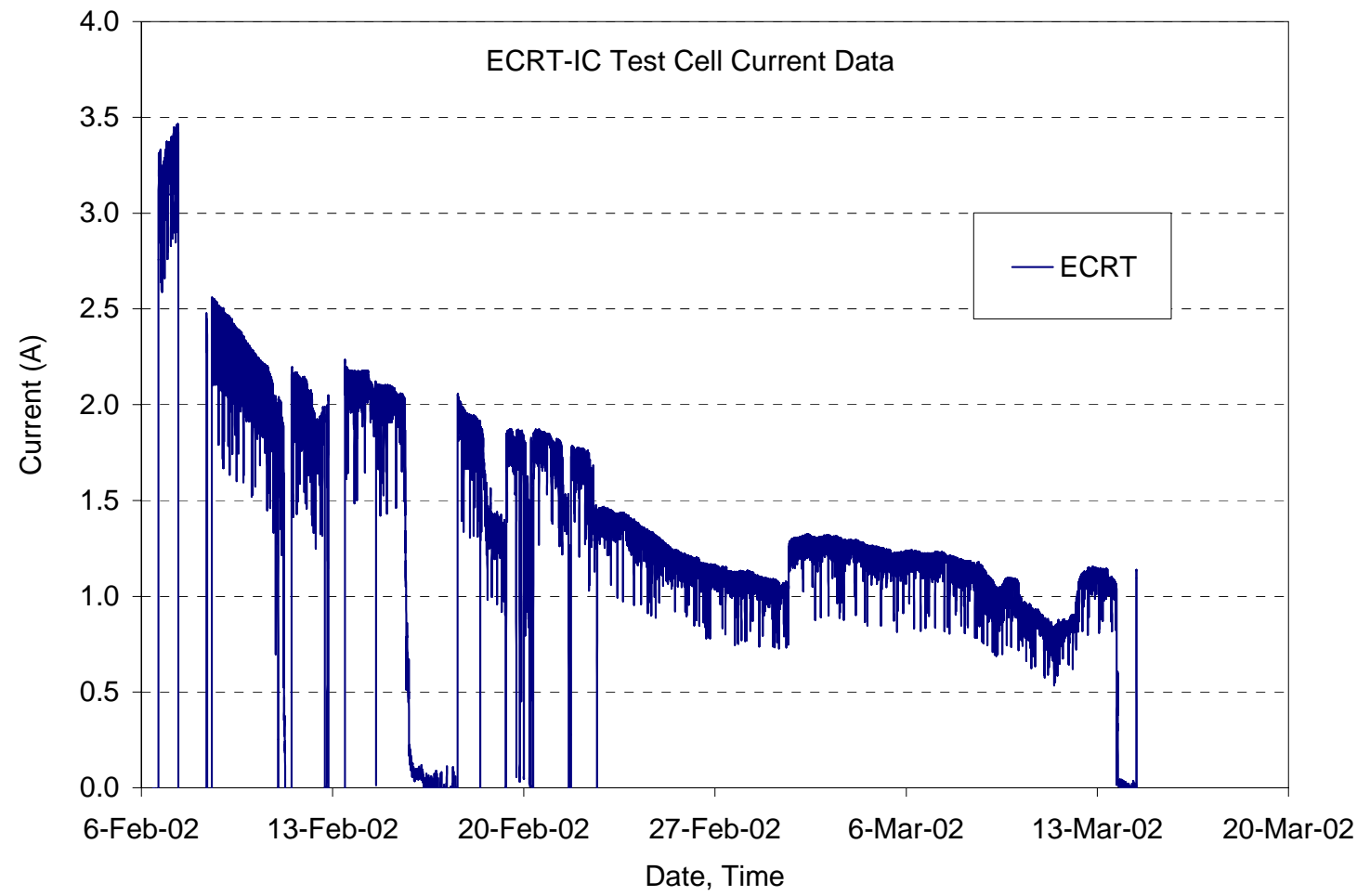

Figure 13 ECRTs-IC test cell current record.

The initial total mercury concentration in the ECRTs-IC Test Cell was $245 \mathrm{mg} / \mathrm{kg}$. This is much lower than the "up to $6,000 \mathrm{mg} / \mathrm{kg}$ ” reported in the Y-12 site characterization and NETL RFP documentation. The lower-than-expected mercury concentration did not require equipment changes, as did the low Y-12 soil resistivity. They did, however, allow some protocol simplification, as the mercury vapor hazards at $245 \mathrm{mg} / \mathrm{kg}$ are much lower than at the anticipated $6,000 \mathrm{mg} / \mathrm{kg}$.

The high iron concentration and lower-than-expected mercury concentration also lowered the ECRTs-IC mercury recovery efficiency, as electrical current input to the cell was required to transport large amounts of iron, in addition to the mercury. Knowledge of concentrations of all 


\section{ECRT-IC Test Cell, Total Mercury Data}

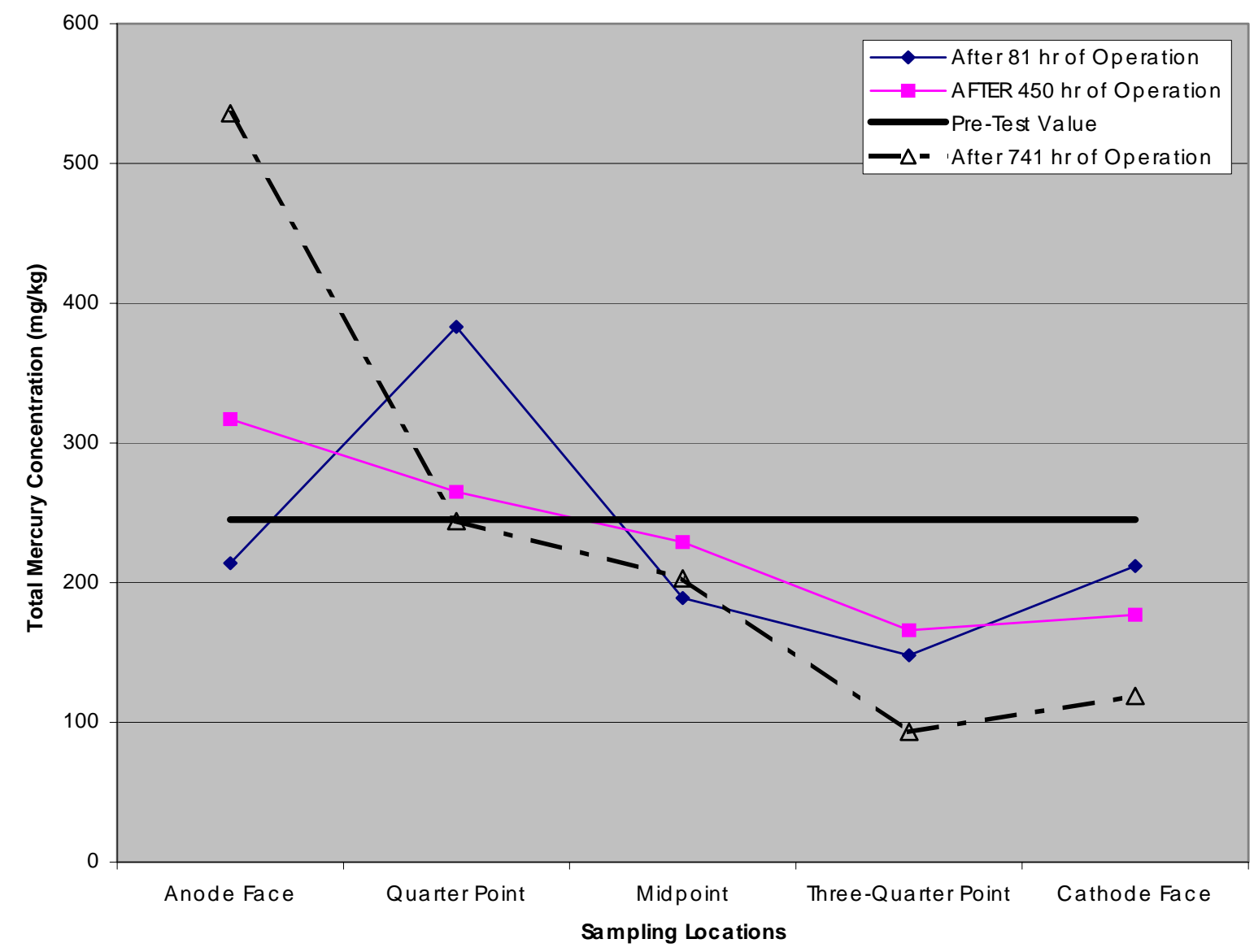

Figure 14 Project ECRTs-IC test cell, total mercury profiles at (1) start of test, (2) after $81 \mathrm{hr}$ of operation, after 450 hr of operation, and after $\mathbf{7 4 1}$ hr of operation. The total mercury distribution shifts over time toward the test cell anode.

contaminants prior to ECRTs-IC system start up is critical to planning the timing of soil sampling. The presence of large concentrations of ions other than the contaminants of interest will reduce the target contaminant remediation efficiency, requiring longer operating time and extending the time between soil sampling.

Figure 14 shows ECRTs-IC Test Cell total mercury distributions changing with time during the test, from uniform at the start, to depleted near the cathode and much greater-than-initial concentration near the anode at the conclusion of the test. This shift of mercury toward the anode is not the behavior expected of metallic ions (i.e., cations) under an electrical field (i.e., electrokinetics) and is taken as evidence that ECRTs induces the formation of high-mobility mercury-complex anions.

Figure 15 shows the TCLP derived mercury distribution at the beginning and end of the ECRTsIC test. The TCLP values of the two sampling points closest to the test cell cathode are well below the NETL defined clean-up goal of 225 ppb mercury in the TCLP leachate. The test cell 
mid-point sample TCLP value is above the clean-up goal, but significantly below the pre-test TCLP value of $940 \mathrm{ppb}$. The TCLP values for the two sampling points closest to the test cell anode are well above the pre-test TCLP value.

The post-test TCLP value pattern is also taken as evidence that the ECRTs-IC operation was mobilizing mercury towards the test cell anode. The laboratory test was not run to completion, due to time and budget constraints. We expect that if more time were available for the test, all the soil within the test cell would have attained TCLP values below the $225 \mathrm{ppb}$ value defined by NETL, as indicated by the two sampling points on the cathode side of the test cell.

\section{ECRT-IC Te st Cell, TCLP Data}

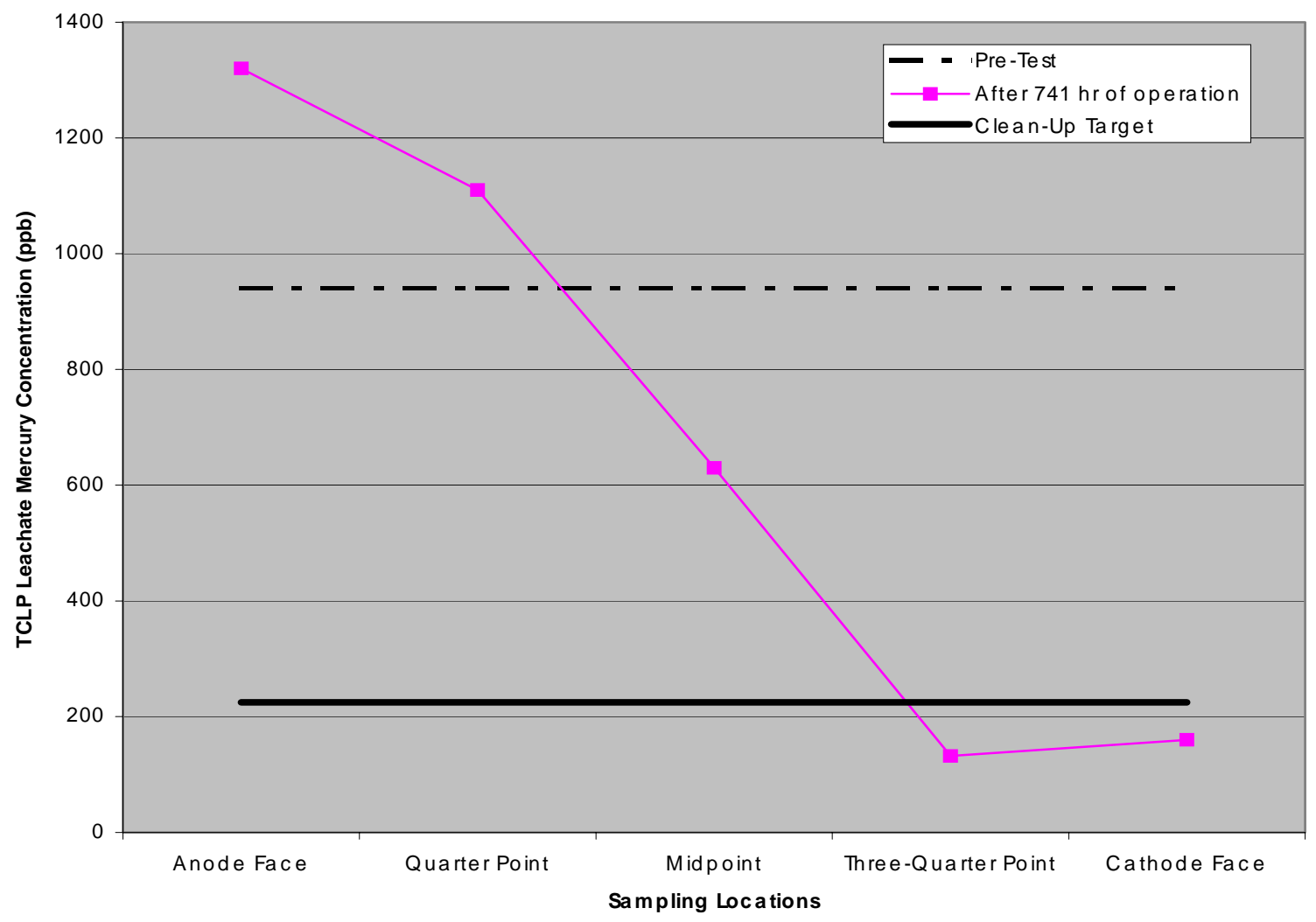

Figure 15 Project ECRT-IC test cell pre- and post-test TCLP values indicate that ECRTs-IC has mobilized mercury and transported it to the test cell anode.

Table 6 summarizes the ECRTs-IC Test Cell mass balance data. From an initial total of 52 gm of mercury, $28.4 \mathrm{gm}$, or $54.62 \%$, was removed by ECRTs-IC operation during the $741 \mathrm{hrs}$ of operation. Post-test analyses indicated that 22.7 gm of mercury remained in the cell. The total post-test analyses accounted for $98.27 \%$ of the initial mercury content of the test cell. The details of this mass balance show that the great majority of mercury in the vicinity of each electrode was in the soil, at the face of the electrode, rather than precipitated onto the electrode. This is in contrast to field experience by the ECRTs developer, where the mercury was precipitated onto the power electrodes. The result is similar to that of a short-term ( $2 \mathrm{hr} .10 \mathrm{~min}$ ) 
demonstration on mercury-contaminated soils from a chlor-alkaline chemical factory in Halle, Germany, which is described above. In that demonstration, a significant amount of mercury collected in sludge in the sump of a well housing the cathode. The mercury collection in the sump sludge was attributed to not running the test to completion. This is also the most likely explanation for the high mercury content in the soil face at the power electrodes in the current test.

Table 6 ECRTs-IC Test Cell Mercury Mass Balance

\begin{tabular}{|l|c|c|}
\hline Item & $\begin{array}{c}\text { Electrode Vicinity } \\
\text { Mass (gm) }\end{array}$ & $\begin{array}{c}\text { ECRTs Test Cell } \\
\text { Summary Mass }\end{array}$ \\
\hline Initial Mercury in Test Cell & & $52.0 \mathrm{gm}$ \\
\hline Mercury on/in Cathode & 0.010 & \\
\hline Mercury in Cathode Rinse Water & 0.002 & \\
\hline Mercury in Soil Rinsed off Cathode & 0.400 & $5.4 \mathrm{gm}$ \\
\hline Mercury in Soil Face at Cathode & 5.000 & \\
\hline Total Cathode Vicinity Mercury & & \\
\hline Mercury in/on Anode & 0.140 & \\
\hline Mercury in Anode Rinse Water & 0.190 & $23.0 \mathrm{gm}$ \\
\hline Mercury in Soil Rinsed off Anode & 0.126 & $28.4 \mathrm{gm}$ \\
\hline Mercury in soil Face at Anode & 22.5 & $54.60 \%$ \\
\hline Total Anode vicinity Mercury & & $22.7 \mathrm{gm}$ \\
\hline Total Recovered Mercury & & $98.30 \%$ \\
\hline Mercury Recovery & & \\
\hline Mercury Still in Soil & & \\
\hline Mass Balance Accounted Mercury & & \\
\hline
\end{tabular}

Table 7 Summary of ECRTs-IC Test Results

\begin{tabular}{|l|c|}
\hline Item & ECRTs-IC Test Cell Results \\
\hline Operation Time & $741 \mathrm{hr}$ \\
\hline Pre-Test Cell Total Mercury & $52 \mathrm{gm}$ \\
\hline Total Mercury Recovered & $28.4 \mathrm{gm}$ \\
\hline Mercury Recovery & $54.62 \%$ \\
\hline Mercury Recovery Rate $(\mathrm{gm} / \mathrm{hr})$ & 0.038 \\
\hline Power Usage & $118.27 \mathrm{~kW}-\mathrm{hr}$ \\
\hline Recovery Efficiency $(\mathrm{gm} / \mathrm{kW}-\mathrm{hr})$ & 0.2401 \\
\hline Power cost @ \$0.10/kW-hr & $\$ 11.83$ \\
\hline
\end{tabular}


Table 7 summarizes the ECRTs-IC test results. A total of 28.4 gm, or $54.62 \%$ of the pre-test contamination, was removed in $741 \mathrm{hr}$ of ECRTs-IC operation. The recovery rate was 0.038 $\mathrm{gm} / \mathrm{hr}$. The mercury recovery efficiency was $0.24 \mathrm{gm} / \mathrm{kW}$-hr. Field experience has provided much higher (up to $26.6 \mathrm{gm} / \mathrm{kW}$-hr) mercury recovery efficiencies.

The low mercury recovery efficiency in the current bench-scale test relative to field operations may be due to:

$>$ the large amount of iron present in $\mathrm{Y}-12$ soil relative to the amount of mercury present reduced the mercury recovery rate;

$>$ limited electrode surface area relative to the test cell dimensions, reduced the mercury recovery rate;

$>$ limited soil volume of the bench-scale test prevented the normal buffering activity of soil in the field, reducing the mercury recovery rate;

$>$ the under-optimized power supply reduced the mercury rate;

$>$ inherent limitations of conducting bench-scale ECRTs tests; and/or,

$>$ some combination of the aforementioned factors.

Successful field scale ECRTs-IC mercury remediation operations at the Union Canal, Scotland and Montluçon, France, suggest that ECRTs-IC remediation of mercury contaminated Y-12 soils should also be successful.

EKAR was developed and optimized in a laboratory setting. By contrast, ECRTs were developed and optimized in field settings. It has been the ECRTs developer's experience that while ECRTs out-performs EKAR in the field, EKAR often out-performs ECRTs in bench-scale tests because of the difficulties in scaling the ECRTs to bench-scale experiments. The current project objective was to evaluate the use of ECRTs-IC to remediate mercury-contaminated Y-12 soils. The EKAR bench-scale test was conducted only to provide a reference for ECRTs.

Because of this test objective, the EKAR results will be presented but not discussed in any detail. The EKAR test commenced on February 6, 2002, and concluded on March 14, 2002. Correcting for system down time, the EKAR test cell was operational for a total of $754 \mathrm{hr}$. The power supply was run under constant voltage conditions. The EKAR power supply voltage output was adjusted to be comparable to that used for the ECRTs-IC test cell. Figures 16 and 17 show the EKAR test cell voltage and current as a function of time, respectively.

The initial mercury concentration in the EKAR test cell was $345 \mathrm{mg} / \mathrm{kg}$. While greater than the initial ECRTs-IC test cell mercury concentration, this is still significantly lower than the "up to $6,000 \mathrm{mg} / \mathrm{kg}$ ” reported in the Y-12 site characterization and NETL RFP. The lower-thanexpected mercury concentrations allowed some protocol simplification, as the mercury vapor hazards at $345 \mathrm{mg} / \mathrm{kg}$ are much lower than at the anticipated 6,000 mg/kg. The EKAR test cell soil also had a high $(1.11 \%)$ initial iron concentration. The high iron concentration and lowerthan-expected mercury concentration also lowered the EKAR mercury recovery efficiency, as 


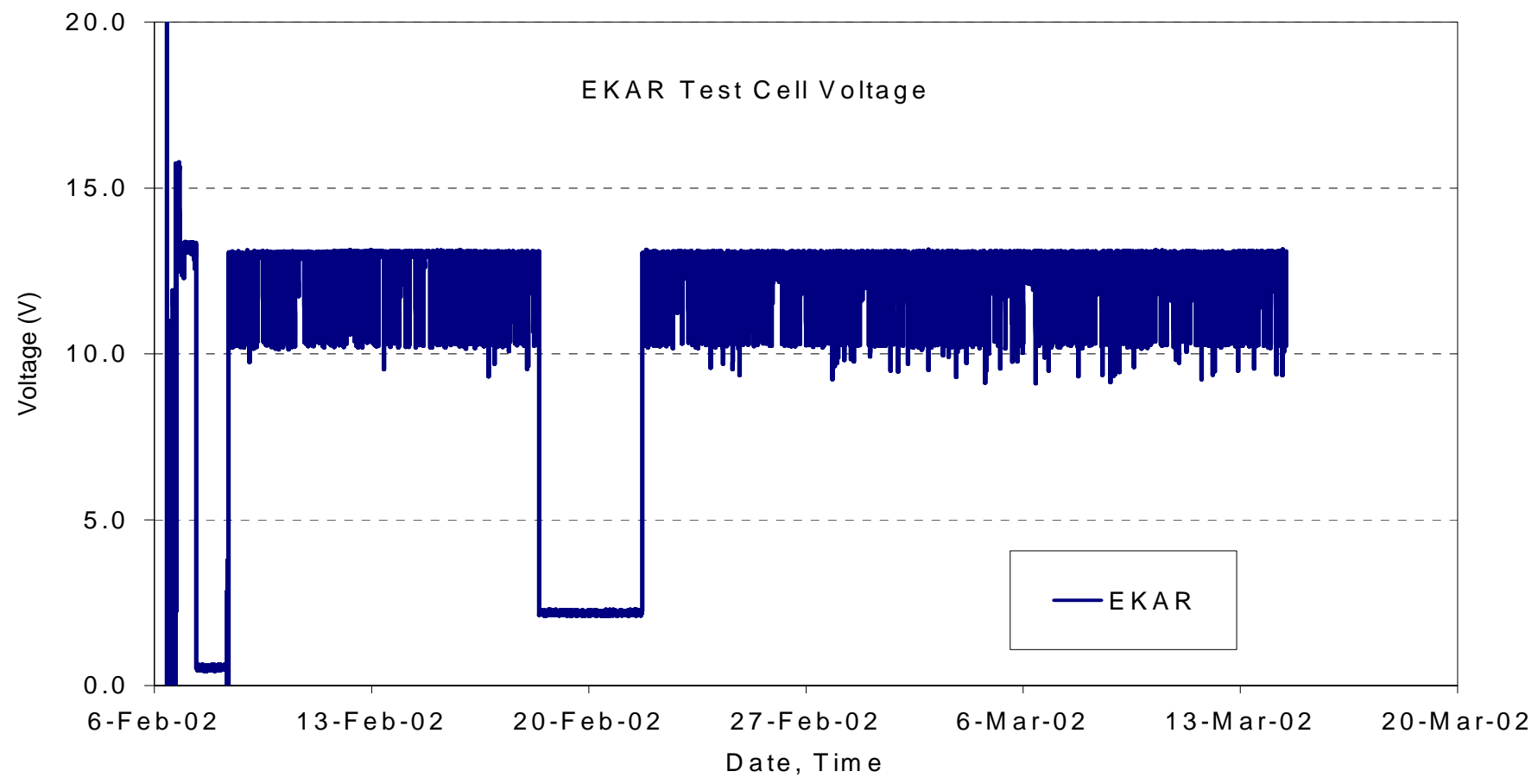

Figure 16 EKAR Test Cell Voltage Record

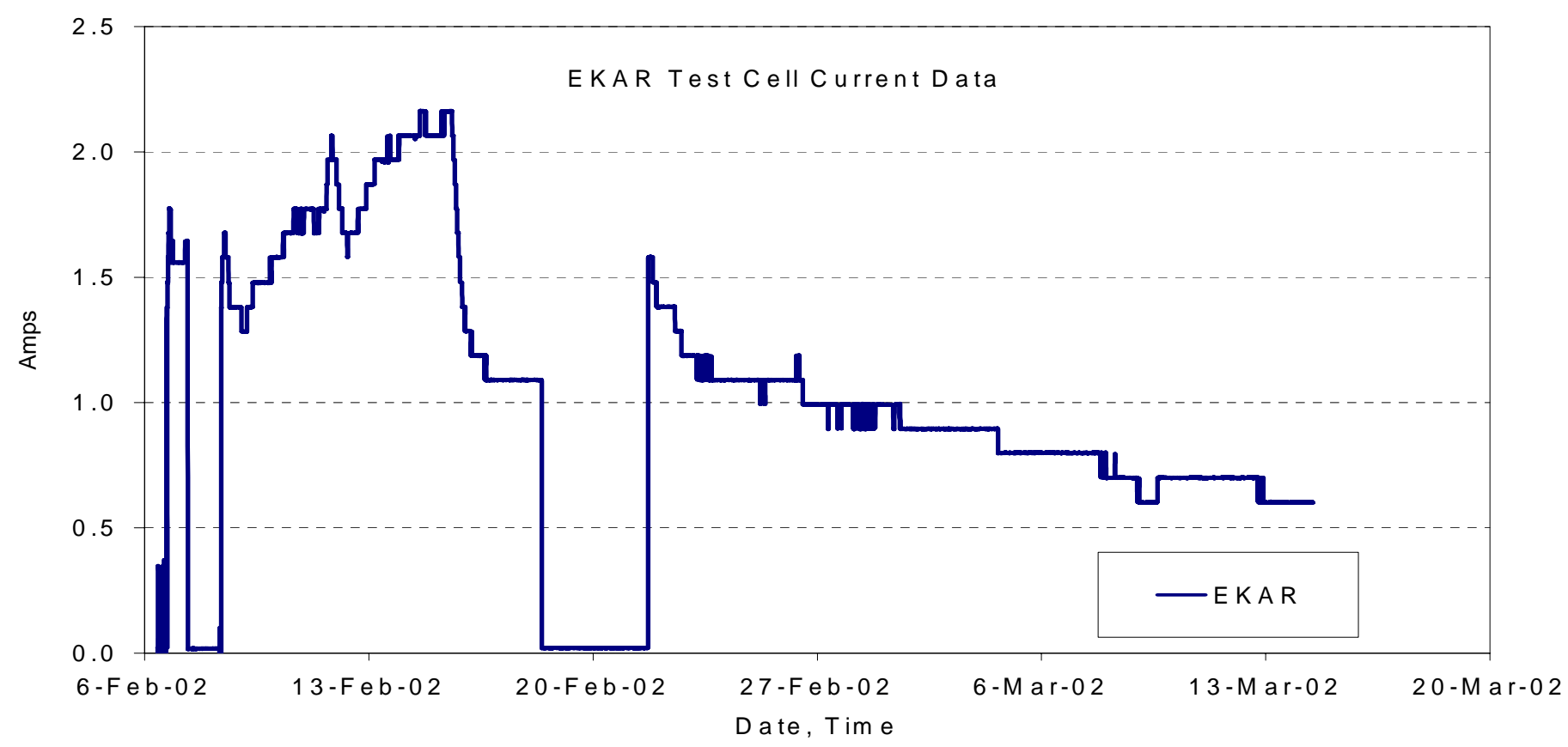

Figure 17 EKAR Test Cell Current Record

electrical current input to the cell was now forced to transport large amounts of iron, in addition to the mercury. 
Figure 18 shows the EKAR test cell total mercury distribution variations with time during the test. In the EKAR test, the changing distributions are not as uniform with time as they were in the ECRTs-IC test cell.

\section{GKARTest Cell, Total Mercury Data}

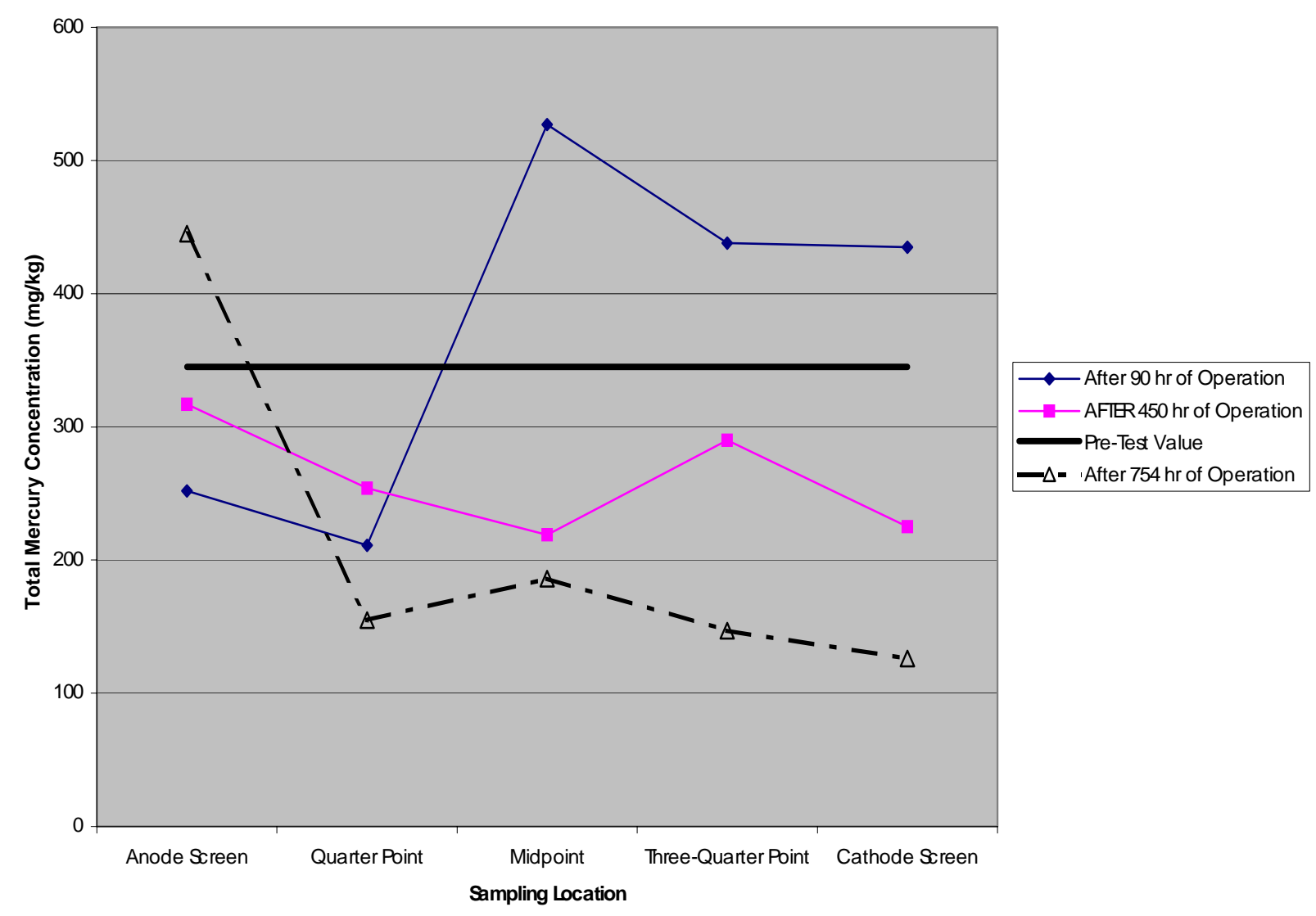

Figure 18 EKAR Test Cell Pre-test and after 90 hr, 450 hr and 754 hr of Operation Total Mercury Distributions

Figure 19 shows the TCLP mercury concentration distribution at the beginning and end of the ECRTs-IC test. None of the TCLP values are below the clean-up goal of 225 ppb mercury in the TCLP leachate. None of the EKAR test cell points sampled had reached the cleanup goal by the completion of the EKAR testing. There is also no clear pattern to the EKAR post-test TCLP data.

The EKAR test was stopped when the ECRTs-IC test was terminated, as the project objective was to evaluate ECRTs-IC.

Table 8 summarizes the EKAR test mass balance. From an initial total of 64 gm of mercury, $22.11 \mathrm{gm}$ (34.55\% of the pre-test contamination) was removed in $754 \mathrm{hr}$ of EKAR operation. Post-test analyses indicated that $18 \mathrm{gm}$ of mercury remained in the test cell. The total post-test mercury analyses accounted for $62.68 \%$ of the initial mercury content of the test cell. 


\section{EKARTest Cell TCLPData}

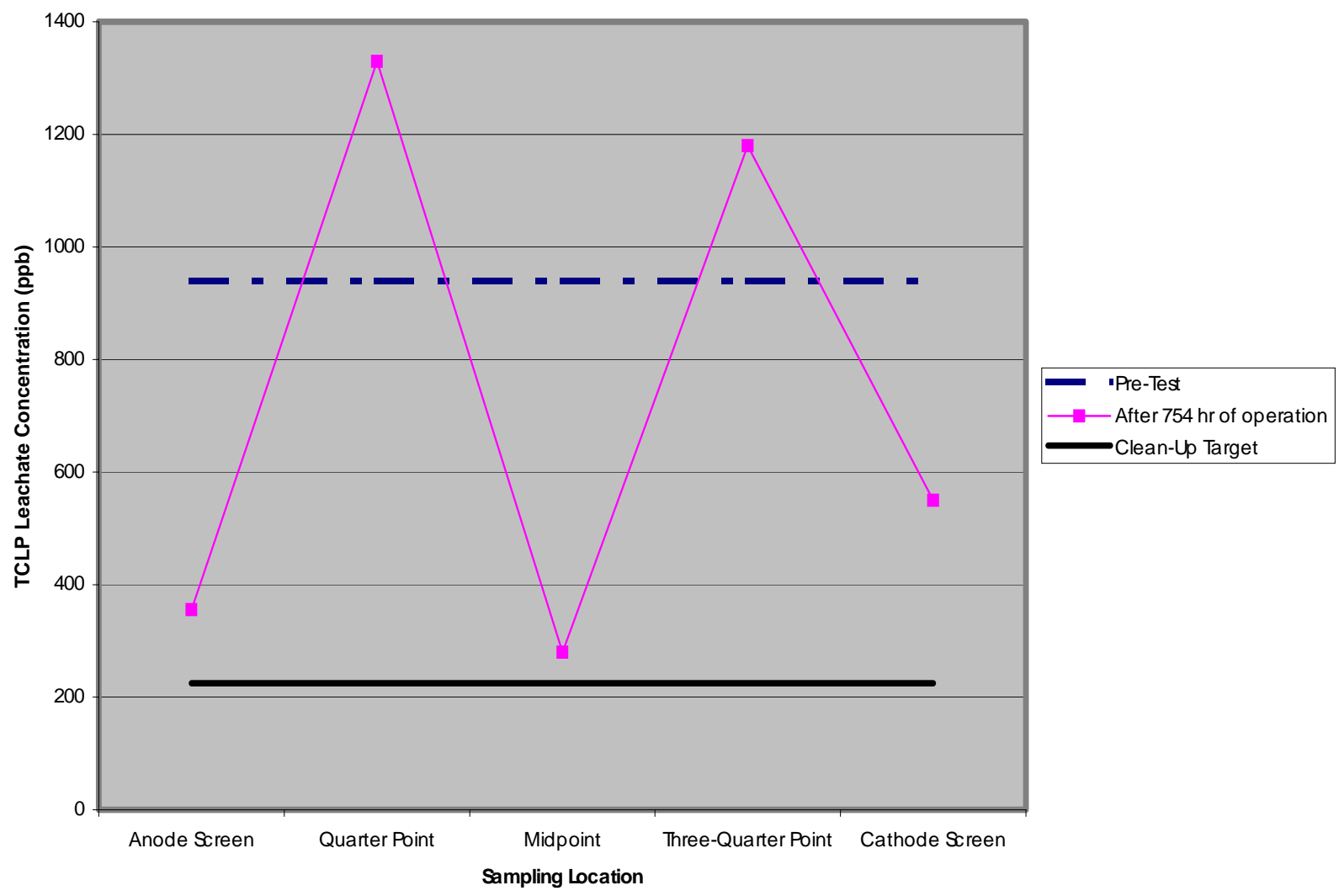

Figure 19 EKAR Test Cell Pre- and Post-test TCLP Values

Table 8 EKAR Test Cell Mercury Mass Balance

\begin{tabular}{|l|c|c|}
\hline Item & $\begin{array}{c}\text { Electrode Vicinity Mass } \\
\text { (gm) }\end{array}$ & $\begin{array}{c}\text { EKAR Test Cell } \\
\text { Mass Balance Summary }\end{array}$ \\
\hline Initial Mercury in Test Cell & & 64 gm \\
\hline Mercury in/on Cathode & 0.94 & \\
\hline $\begin{array}{l}\text { Mercury in Soil at Cathode } \\
\text { Membrane }\end{array}$ & 4.6 & $5.54 \mathrm{gm}$ \\
\hline $\begin{array}{l}\text { Total Cathode Vicinity } \\
\text { Mercury }\end{array}$ & & \\
\hline Mercury in/on Anode & 0 & \\
\hline $\begin{array}{l}\text { Mercury in Soil at Anode } \\
\text { Membrane }\end{array}$ & 16.4 & $16.4 \mathrm{gm}$ \\
\hline Total Anode Vicinity Mercury & & $0.173 \mathrm{gm}$ \\
\hline Total Mercury on IX & & \\
\hline
\end{tabular}




\begin{tabular}{|l|c|c|}
\hline Item & $\begin{array}{c}\text { Electrode Vicinity Mass } \\
\text { (gm) }\end{array}$ & $\begin{array}{c}\text { EKAR Test Cell } \\
\text { Mass Balance Summary }\end{array}$ \\
\hline Exchange Column Resin & & \\
\hline Total Recovered Mercury & & $22.113 \mathrm{gm}$ \\
\hline Mercury Recovery & & $34.55 \%$ \\
\hline Mercury Still in Soil & & $18 \mathrm{gm}$ \\
\hline $\begin{array}{l}\text { Mass Balance Accounted } \\
\text { Mercury }\end{array}$ & & $62.68 \%$ \\
\hline
\end{tabular}

Table 9 summarizes the EKAR test results. A total of 21.113 gm of mercury, or $34.55 \%$ of the pre-test contamination, was removed in $754 \mathrm{hr}$ of EKAR operation. The recovery rate was $0.0280 \mathrm{gm} / \mathrm{hr}$. The mercury recovery efficiency was $0.12 \mathrm{gm} / \mathrm{kW}$-hr.

Table 9 Summary of EKAR Test Results

\begin{tabular}{|l|c|}
\hline Item & EKAR Test Cell Results \\
\hline Operation Time & $754 \mathrm{hr}$ \\
\hline Pre-Test Cell Total Mercury & $64 \mathrm{gm}$ \\
\hline Total Mercury Recovered & $21.113 \mathrm{gm}$ \\
\hline Mercury Recovery & $34.55 \%$ \\
\hline Mercury Recovery Rate & $0.0280 \mathrm{gm} / \mathrm{hr}$ \\
\hline Power Usage & $182.92 \mathrm{~kW}-\mathrm{hr}$ \\
\hline Recovery Efficiency & $0.1159 \mathrm{gm} / \mathrm{kW}-\mathrm{hr}$ \\
\hline Power cost @ \$0.10/kW-hr & $\$ 18.29$ \\
\hline
\end{tabular}

\section{Results Demonstrating Achievement}

In the above section of this report addressing the methodology used by the Team, four goals that would define the success of the ECRTs-IC bench-scale test were identified:

$>$ Mercury is mobilized to both the anode and the cathode.

$>$ Mercury is precipitated on one or both power electrodes.

$>$ Demonstrated mercury concentration reduction below the work plan-defined TCLP level of $0.25 \mathrm{mg} / \mathrm{L}$ in the TCLP leachate.

$>$ The ECRTs-IC test cell recovery rate meets or exceeds that of the EKAR test cell.

Condition 1 has been satisfied, as evidenced by the ECRTs-IC test cell mass balance summarized in Table 6 above, which listed 5.4 gm mercury at the cathode and 23 gm mercury at the anode. The total mercury data (Figure 14) shows a steady mobilization and movement of mercury toward the test cell anode. This behavior (metals movement toward the anode) is indicative of the formation of complex metallic anions, as is claimed for ECRTs-IC. 
The details of the ECRTs-IC test cell mercury mass balance show that Condition 2 was met:

$>$ Mercury was obtained from both the anode and the cathode.

$>$ The soil washed from both electrodes after removal from the cell contained mercury.

$>$ The wash water from both electrodes contained mercury.

$>$ The soil immediately next to both electrodes contained mercury.

Condition 3 has been satisfied, as evidenced by the ECRTs-IC test cell post-test TCLP data (Figure 15). The two sampling locations closest to the cathode have TCLP values below the 250 ppb clean up target. The ECRTs-IC test cell evidences cleanup to below the designated level near the cathode but the test was not run to conclusion, due to time and budget consideration. We fully expect that had the ECRTs-IC test cell been run to completion, we would have obtained TCLP values below the cleanup target throughout the test cell.

Table 8 compares the performance of the ECRTs-IC and EKAR test cells, using several performance measures. In all three cases, ECRTs-IC outperforms EKAR. The ECRTs-IC recovery rate is 1.6 times that of EKAR, which satisfies success condition 4.

Table 10. Comparison of ECRTs-IC and EKAR Performance Measures

\begin{tabular}{|l|c|c|}
\hline Measure & ECRTs-IC Test Cell & EKAR Test Cell \\
\hline Mercury Recovery & $54.62 \%$ & $34.55 \%$ \\
\hline Mercury Recovery Rate & $0.038 \mathrm{gm} / \mathrm{hr}$ & $0.028 \mathrm{gm} / \mathrm{hr}$ \\
\hline $\begin{array}{l}\text { Mercury Recovery } \\
\text { Efficiency }\end{array}$ & $0.2401 \mathrm{gm} / \mathrm{kW}-\mathrm{hr}$ & $0.1159 \mathrm{gm} / \mathrm{kW}-\mathrm{hr}$ \\
\hline
\end{tabular}

\section{Discussion \& Interpretation of Results}

The ECRTs-IC bench-scale test met the success criteria established in the test work plan, as described above.

$>$ Mercury was mobilized to both the anode and the cathode.

$>$ Mercury was precipitated on one or both power electrodes.

$>$ Mercury concentration was reduced below the work plan-defined TCLP level of $0.25 \mathrm{mg} / \mathrm{L}$ in the TCLP leachate.

$>$ Mercury recovery rate in the ECRTs-IC test cell met or exceeded that in the EKAR test cell.

In addition, ECRTs-IC performance was measured against EKAR performance in the following areas to determine which process worked better:

Mercury recovery.

$>$ Mercury recovery rate.

$>$ Mercury recovery efficiency. 
The ECRTs-IC test cell outperformed the EKAR test cell for all of these measures even though ECRTs-IC is not optimized for laboratory testing as EKAR is. ECRTs-IC does not require any pumping, exchange columns, or electrode buffering, which EKAR does, resulting in lower O\&M costs for ECRTs-IC relative to EKAR. Most importantly, field ECRTs-IC mercury remediation case histories greatly outperformed the ECRTs-IC test cell for all of the performance measurements cited above (see discussion below). This last observation substantiates the ECRTs developer's claim that bench-scale ECRTs-IC tests should not be used to predict ECRTs-IC field system performance. Because of this, we are including some ECRTs-IC heavy metal remediation case histories, to show how the ECRTs developer uses bench scale testing to demonstrate the technology, but does not use bench scale results to predict field operation results.

\section{Halle, Germany}

Soil from a nearby chlor-alkaline chemical factory was used in a modest sized $(46.5 \mathrm{~cm} \mathrm{x} 29 \mathrm{~cm}$ x $29 \mathrm{~cm}$ test cell filled to $19 \mathrm{~cm}$ depth) bench-scale test cell to demonstrate ECRTs-IC mobilization and transport of metallic mercury. Two rod electrodes were installed at a spacing of $38.5 \mathrm{~cm}$, with the cathode housed in a special well casing with vertical slots. The test duration was very short, $2 \mathrm{hr}$. $10 \mathrm{~min}$, since the purpose was to demonstrate the mobilization and transport of metallic mercury, not quantify it. At the conclusion of the test:

$>$ The anode showed high rates of corrosion.

$>$ The cathode was covered with a silvery coat, which could not be washed off.

$>$ Analysis of the cathode revealed that 30.2 gm of mercury was deposited on the cathode.

$>$ The cathode well tube was filled with sludge, which yielded $138 \mathrm{gm}$ of metallic mercury.

The above results were obtained in a little over two hours of ECRTs-IC test cell operation. No more quantitative analyses were attempted. These results, however, were sufficient to convince a skeptical panel of experts convened by the client that ECRTs-IC was a viable technology for in-situ mobilization and removal of metallic mercury.

\section{Union Canal, Scotland}

This site was a former transportation canal, used to transport supplies to and products from a former detonator factory. The silts in the bottom of the canal contained elemental and organic mercury in concentrations which ranged from $33 \mathrm{mg} / \mathrm{kg}$ to $890 \mathrm{mg} / \mathrm{kg}$, with an average value of $243 \mathrm{mg} / \mathrm{kg}$. An estimated $220 \mathrm{~m}^{3}$ of this sediment was remediated, in-situ, using ECRTs-IC. After 26 days of ECRTs-IC, using an average power input of $5.6 \mathrm{~kW}, 72 \mathrm{~kg}$ of mercury was plated onto the power electrodes. A re-sampling of the site revealed that the average mercury level had decreased to $6 \mathrm{mg} / \mathrm{kg}$, well below the clean-up target of $20 \mathrm{mg} / \mathrm{kg}$.

\section{Montluçon, France}

This case history involved approximately $350 \mathrm{~m}^{3}$ of sewerage sludge contaminated with mercury amalgams, treated $e x$-situ, using temporary holding ponds. Initial sampling indicated an average of $28 \mathrm{mg} / \mathrm{kg}$ mercury concentration in the sludge. The clean-up goal was $5 \mathrm{mg} / \mathrm{kg}$ mercury. After seven days of $2.3 \mathrm{~kW}$ ECRTs-IC, the sludge was re-sampled. The average mercury concentration at this time was $0.126 \mathrm{mg} / \mathrm{kg}$, well under the clean-up target of $5 \mathrm{mg} / \mathrm{kg}$. 


\section{Luebeck-Herrenwyk, Germany}

The site was a former steel mill with heavy metals, PAH, BTEX, phenols, cyanides, TPH and other pollutants to a depth of $18 \mathrm{~m}$. A short-term (10 days) test was conducted to demonstrate using ECRTs-IC for in-situ heavy metals remediation. Because the object of this test was only to demonstrate the technology, rather than evaluate its effectiveness, the test was not run to completion and only minimal analytical work was completed.

The ECRTs-IC test cell consisted of a large (load lugger type) container, which also served as the ECRTs-IC cathode. The container was filled with $11 \mathrm{~T}$ of dark brown loamish silt sediment. A plate anode was placed in the center of the soil in the container.

The test was run for 10 days at $3.8 \mathrm{~kW}$ of power. Table 9 shows the pre-test and post-test heavy metal contaminant concentrations, as well as the implied recovery rate. The electrodes were not analyzed after the test and no mass balance was attempted, because of the incomplete chemical information.

Table 11 Luebeck-Herrenwyk Container Test Results

\begin{tabular}{|l|c|c|c|}
\hline Contaminant & $\begin{array}{c}\text { Pre-Test } \\
\text { Concentration } \\
\mathbf{( m g / k g )}\end{array}$ & $\begin{array}{c}\text { Post-Test } \\
\text { Concentration } \\
\mathbf{( m g / k g )}\end{array}$ & $\begin{array}{c}\text { Contaminant } \\
\text { Reduction } \\
\text { (\% Pre-Test) }\end{array}$ \\
\hline Arsenic & 34 & 28 & 17.6 \\
\hline Copper & 330 & 150 & 54.6 \\
\hline Lead & 400 & 210 & 47.5 \\
\hline Zinc & 1200 & 640 & 46.7 \\
\hline
\end{tabular}

Comparing Table 9 with Tables 10 and 11 indicate that pre-test concentrations do not have any relationship with contaminant reduction percentages.

\section{Hamburg, Germany}

This was a bench-scale test to demonstrate ECRTs-IC remediation of multiple heavy metal contamination of Hamburg Harbor sediments. The ECRTs-IC test cell consisted of a $100 \mathrm{~cm} \mathrm{x}$ $40 \mathrm{~cm}$ x $40 \mathrm{~cm}$ glass walled fish tank.

The test was run for 14 days at $168 \mathrm{~W}$. Because it was a demonstration, the test was not run to completion. Table 10 shows the pre-test and post-test concentrations, as well as the implied percent reduction. The electrodes were not analyzed after the test and no mass balance was attempted. 
Table 12 Hamburg Port Sludge Results

\begin{tabular}{|l|c|c|c|}
\hline Contaminant & $\begin{array}{c}\text { Pre-Test } \\
\text { Concentration } \\
(\mathbf{m g} / \mathbf{k g})\end{array}$ & $\begin{array}{c}\text { Post-Test } \\
\text { Concentration } \\
\mathbf{( m g / k g )}\end{array}$ & $\begin{array}{c}\text { Contaminant } \\
\text { Reduction } \\
\text { (\% Pre-Test) }\end{array}$ \\
\hline Arsenic & 13 & 2.3 & 82.3 \\
\hline Cadmium & 10 & 2 & 80.0 \\
\hline Copper & 143 & 12 & 91.6 \\
\hline Total Chrome & 72 & 16 & 77.8 \\
\hline Lead & 173 & 38 & 78.0 \\
\hline Mercury & 0.5 & $<0.1$ & $>80.0$ \\
\hline Nickel & 56 & 5 & 91.1 \\
\hline Zinc & 901 & 54 & 94.0 \\
\hline
\end{tabular}

\section{Finnow, Germany}

This ECRTs-IC field demonstration was conducted in a waste-water lagoon at a former metals (steel, aluminum, copper and brass) rolling mill. Waste waters from the metals rolling operations were discharged into abandoned clay pits along with blasting sands and fine metallic particles (primarily iron and copper blasting dust). An estimated $210 \mathrm{~m}^{3}$ of heavy metals (arsenic, cadmium, copper chromium, lead, nickel and zinc) contaminated sediment was remediated, using ECRTs-IC, for 30 days. Approximately $8.5 \mathrm{~kg}$ of heavy metals were precipitated onto both power electrodes (38\% at the anode and $62 \%$ at the cathode). Table 11 summarizes the results of this field ECRTs-IC operation. Heavy metals recovery ranged from $75 \%$ to essentially $100 \%$, for the various heavy metal contaminants.

Table 13 Finnow Rolling Mill Waste-Water Settling Lagoon

\begin{tabular}{|l|c|c|c|}
\hline Contaminant & $\begin{array}{c}\text { Pre-Test } \\
\text { Concentration } \\
(\mathbf{m g} / \mathbf{k g})\end{array}$ & $\begin{array}{c}\text { Post-Test } \\
\text { Concentration } \\
\text { (mg/kg) }\end{array}$ & $\begin{array}{c}\text { Contaminant } \\
\text { Recovery } \\
\text { (\% Pre-Test) }\end{array}$ \\
\hline Arsenic & 92 & 30 & 67.4 \\
\hline Cadmium & 0.5 & N.D. & NQ \\
\hline Copper & 48,000 & 4,000 & 91.7 \\
\hline Total Chromium & 49 & 6.1 & 87.6 \\
\hline Lead & 400 & 100 & 75.0 \\
\hline Nickel & 0.53 & 0.11 & 79.2 \\
\hline Zinc & 4,800 & 170 & 96.5 \\
\hline
\end{tabular}




\section{Unanticipated and Unproductive Results}

The Team did not encounter any serious unexpected or unproductive results. However, several observations/results were identified that the Team did not anticipate when the ECRTs-IC proposal was submitted.

$>$ The NETL RFP anticipated mercury contamination levels of up to 6,000 $\mathrm{mg} / \mathrm{kg}$. The average of the blended Y-12 soil samples was $252+/-36 \mathrm{mg} / \mathrm{kg}$ and the ECRTs-IC test cell pre-test level was $245 \mathrm{mg} / \mathrm{kg}$. This unanticipated difference actually simplified operations as the H\&S issues with $245 \mathrm{mg} / \mathrm{kg}$ are much less than with $6,000 \mathrm{mg} / \mathrm{kg}$.

$>$ Because there were no electrical resistivity measurements available for the Y-12 soil, the test equipment requirements were based on the ECRTs developer's past experience, which suggested that we should expect a system resistance for the soil-filled ECRTs-IC test cell of approximately $100 \mathrm{ohm}$. In fact, the Y-12 soil had very low resistivity, such that the initial test cell resistance was approximately $6 \mathrm{ohm}$. The high voltage/low current-rated ECRTs-IC power supply initially secured for the tests needed to be replaced by a power supply which could accommodate higher currents. The only power supply available on short notice would not go above $14 \mathrm{~V}$, which limited the current strength available for the test cell. This will not pose a problem for field operations because:

o Field ECRTs power supplies can handle much wider ranges of voltage and current loads than the bench-top units used for the Phase I tests.

o Because we now know the low resistivity nature of the $\mathrm{Y}-12$ soil, this can be designed into the field ECRTs-IC power electrode array.

Any future bench scale testing will require:

o Sample resistivity information with the matrix, or provisions for sample resistivity measurement as part of the ECRTs-IC bench-scale test program.

o More robust (greater voltage and current range) ECRTs-IC power supplies than were available for the Phase I testing.

$>$ The Y-12 soil had very high (1.2\%, by weight) iron content, which may have decreased the ECRTs-IC mercury removal efficiency. This problem can be solved by engineering design changes in the field ECRTs-IC system.

$>$ A significant amount of mercury was left in the soil immediately adjacent to the power electrodes. This is attributed to the fact that the test did not run to completion (i.e., all mercury being deposited at the electrodes), due to project schedule and budget considerations. We anticipate field demonstration operations will run to completion.

$>$ Not all of the soil in the ECRTs-IC test cell was below the clean-up target level at the conclusion of the testing. We attribute this to the fact that the ECRTs-IC operation was not allowed to run to conclusion because of budget and time considerations. Field ECRTs-IC operations will be run to conclusion.

None of the above unexpected observations/results were fatal to the successful conclusion of the Phase I testing. All of them have rather straightforward engineered or administrative solutions. Sections of the ECRTs-IC cathode and anode were cut into approximately 1- to 2-cm square pieces and tested for mercury following the TCLP protocol (Table 12). The testing found that 
mercury levels were already below the regulatory limit of $200 \mathrm{ppb}$. Consequently, no further "stabilization" was undertaken on the electrode pieces.

Table 14 Analysis of ECRTs electrodes.

\begin{tabular}{|c|c|c|c|c|c|c|}
\hline Electrode & $\begin{array}{l}\text { Sample from } \\
\text { Section }\end{array}$ & $\begin{array}{l}\text { Sample } \\
\text { Size }\end{array}$ & Analysis & $\begin{array}{c}\mathrm{Hg} \\
(\mathrm{ppb})\end{array}$ & $\begin{array}{c}\mathrm{Hg} \\
(\mathrm{mg} / \mathrm{kg})\end{array}$ & Sample Prep. \\
\hline$\overline{\text { ECRT steel }}$ & 7 & $20 \mathrm{~g}$ & TCLP & 37 & & 1-cm squares \\
\hline ECRT steel & 11 & $20 \mathrm{~g}$ & TCLP & 3 & & 1-cm squares \\
\hline ECRT graphite & 7 & $20 \mathrm{~g}$ & TCLP & 17 & & 2-cm chunks \\
\hline ECRT graphite & 11 & $20 \mathrm{~g}$ & TCLP & 93 & & 2-cm chunks \\
\hline ECRT graphite & 11 & $20 \mathrm{~g}$ & TCLP & 87 & & 2-cm chunks \\
\hline ECRT graphite & 2 & $0.5 \mathrm{~g}$ & total $\mathrm{Hg}$ & & 17.3 & pulverized \\
\hline ECRT graphite & 2 & $0.5 \mathrm{~g}$ & total $\mathrm{Hg}$ & & 17.1 & pulverized \\
\hline ECRT graphite & 2 & $0.5 \mathrm{~g}$ & total $\mathrm{Hg}$ & & 19.2 & pulverized \\
\hline ECRT graphite & 14 & $0.5 \mathrm{~g}$ & total $\mathrm{Hg}$ & & 44.2 & pulverized \\
\hline ECRT graphite & 14 & $0.5 \mathrm{~g}$ & total $\mathrm{Hg}$ & & 43.9 & pulverized \\
\hline \multirow[t]{2}{*}{ ECRT graphite } & 14 & $0.5 \mathrm{~g}$ & total $\mathrm{Hg}$ & & 44.8 & pulverized \\
\hline & & & & $\operatorname{avg}=$ & 31 & \\
\hline ECRT steel & 2 & $5 \mathrm{~g}$ & total $\mathrm{Hg}$ & & 4.83 & 1-cm squares \\
\hline ECRT steel & 14 & $5 \mathrm{~g}$ & total $\mathrm{Hg}$ & & 3.24 & 1-cm squares \\
\hline ECRT steel & 2 & $0.5-1.0 \mathrm{~g}$ & total Hg & & 12.9 & one $1-\mathrm{cm}$ square \\
\hline ECRT steel & 2 & $0.5-1.0 \mathrm{~g}$ & total $\mathrm{Hg}$ & & 2.6 & one $1-\mathrm{cm}$ square \\
\hline ECRT steel & 2 & $0.5-1.0 \mathrm{~g}$ & total Hg & & 26.2 & one $1-\mathrm{cm}$ square \\
\hline ECRT steel & 14 & $0.5-1.0 q$ & total $\mathrm{Ha}$ & & 4.56 & one 1-cm square \\
\hline ECRT steel & 14 & $0.5-1.0 \mathrm{~g}$ & total $\mathrm{Hg}$ & & 4.87 & one $1-\mathrm{cm}$ square \\
\hline \multirow[t]{2}{*}{ ECRT steel } & 14 & $0.5-1.0 \mathrm{~g}$ & total $\mathrm{Hg}$ & & 3.97 & one $1-\mathrm{cm}$ square \\
\hline & & & & $\operatorname{avg}=$ & 7.9 & \\
\hline
\end{tabular}

\section{Environment, Safety and Health Considerations}

\section{Pre-demonstration Activities}

The prime maintained primary responsibility for Environment, Safety \& Health (ES\&H) oversight as part of its role as project manager. The Safety and Health Plan (S\&HP) served as the basis of this oversight. The S\&HP is consistent and is in accordance with applicable Federal, State and local laws, including codes, ordinances, and regulations. The S\&HP codifies and summarizes procedures, equipment, and work practices intended to protect the safety and health of employees and public and complies with all legally required safety and health regulations. In particular, the S\&HP describes policies and procedures to be followed in order to keep chemical exposure below approved levels and contains specific instructions for handling hazardous chemicals. It also describes circumstances under which medical consultations and examinations are required.

An Environmental Protection Program (EPP) plan will be developed for the field work. The plan will be designed to safeguard environmental resources with respect to the work being performed as required by applicable Federal, State, and local laws, including codes, ordinances, and regulations.

Specific activities undertaken to ensure compliance are outlined in Table 13 below. 
Table 15 ES\&H Guidance and Actions

\begin{tabular}{|c|c|c|}
\hline AREA/SUBJECT & REQUIREMENT & DOCUMENTATION \\
\hline Hazard Communication & Written program & $\begin{array}{l}\text { Get a copy of the program } \\
\text { Get documentation of training }\end{array}$ \\
\hline Hazcom (MSDS’s) & $\begin{array}{l}\text { MSDS's must be maintained } \\
\text { for all hazardous materials }\end{array}$ & $\begin{array}{l}\text { Get list and copies of some } \\
\text { examples. }\end{array}$ \\
\hline EPCRA & $\begin{array}{l}\text { Compliance with Emergency } \\
\text { Planning \& Community } \\
\text { Right-to-Know Act }\end{array}$ & $\begin{array}{l}\text { Written documentation } \\
313 \text { Inventory forms }\end{array}$ \\
\hline Pollution Prevention Act & $\begin{array}{l}\text { Compliance with Section } \\
6607 \text { of the PPA }\end{array}$ & $\begin{array}{l}\text { Get copy of written program } \\
\text { (specifically the section that } \\
\text { describes source reduction } \\
\text { and recycling data) }\end{array}$ \\
\hline Substance Abuse & See Contract & $\begin{array}{l}\text { Get a copy of written program } \\
\text { Ensure that all employees } \\
\text { have been notified of the } \\
\text { contractors sub abuse policy }\end{array}$ \\
\hline $\begin{array}{l}\text { Toxic Chemical Release } \\
\text { Reporting }\end{array}$ & $\begin{array}{l}\text { Compliance with filing } \\
\text { requirements for “form R" }\end{array}$ & Get copy(s) of form R files \\
\hline NEPA & Compliance with NEPA & $\begin{aligned} \text { Ask for copies of : } \\
\text { 1. Hazardous Substance } \\
\text { Plan } \\
\text { 2. Hazardous Waste } \\
\text { Report } \\
\text { 3. Environmental } \\
\text { Compliance Plan } \\
\text { 4. Envir. Monitoring } \\
\text { Plan } \\
\text { 5. Envir. Status Reports }\end{aligned}$ \\
\hline
\end{tabular}

The experiments were carried out in a permitted laboratory in Golden, Colo., under the direction of project personnel. Descriptions of the experiments are provided earlier in this document. Since the planned work was to be carried out in a laboratory, environmental issues consisted of delivery and handling of contaminated soil samples to be used in testing, disposal of treated wastes upon completion of the experiments, and follow-up handling of the mercurycontaminated electrodes generated in the laboratory.

The actual hazards were less than assumed in the initial planning for several reasons: (1) the amount of mercury in the soil was substantially less than anticipated; (2) the soil was not radioactive; and, (3) the required voltage/current regime used in the testing was only 12 VDC and approximately 2 amps. For these reasons, the PPE requirements were lowered to the use of standard laboratory gear, namely protective gloves and eyewear. Changes to the Work Plan were documented and approved prior to implementation. 
The test cells were situated in laboratory hoods with controlled ventilation flow filtered to capture any mercury vapor or radioactive gas emissions that may be released. The test cells themselves were covered to minimize the potential for emissions. Technicians and project engineering personnel were present in the testing laboratory only when necessary.

The test material was blended in a polydrum rather than the originally planned mortar mixer. The drum was sealed during mixing to eliminate possible vapor and dust emissions. This change simplified cleanup and decontamination procedures.

All waste materials (soil samples, sampling equipment, contaminated PPE) were drummed for return to Y-12 as originally planned. The original overpack drums used to ship the soil to the test laboratory were reused for the return shipment. At the time of this writing, the materials were still being held at test laboratory (soil and PPE) and the mercury stabilization subcontractor (samples) pending completion of the Final Report. The materials will be combined and returned to $\mathrm{Y}-12$ in a single shipment.

\section{Conclusions and Recommendations}

\section{Conclusions}

Bench-scale tests offer the researcher an opportunity to demonstrate the validity of their concept and to learn how their concept will perform under given circumstances. The Demonstration of ElectroChemical Remediation Technologies accomplished both of these objectives. First, the bench-scale tests proved that ECRTs-IC works and that it works better than EKAR. Second and more important, the proof of process testing performed on the bench level demonstrates that ECRTs-IC is a significant new weapon in the environmental remediation industry's arsenal and is especially valid to the problems faced by the U.S. Department of Energy at its former weapons sites.

ECRTs-IC is an in-situ remediation technology and as such, can be applied under buildings and in aquatic conditions. Other ECRTs-IC case histories show reductions in other metal contaminants also. Thus, this technology can also remediate heavy metals and heavy-metal radionuclides in the same fashion as it has remediated mercury. This capability will eliminate the need for excavation and transportation of metal and heavy metal radionuclide contaminated soil and sediment. We anticipate that implementation of in-situ ECRTs-IC at DOE sites with mercury contaminated soil will result in faster and more cost-effective mercury remediation with less disruption of site activities relative to the baseline technology which involves excavation, low temperature desorption, and disposal.

\section{Cost Comparison}

Low-temperature thermal desorption costs are estimated at \$700/CY exclusive of the excavation, hauling, and disposal costs (DOE NETL Solicitation No. PRDA DE-RA26-01NT41020 and subsequent Offeror Q/A Responses). General, commercial Preliminary Engineering Cost Estimates (PECE) for upland ECRTs remediation sites range from $\$ 135 / C Y$ for remediation volumes on the order of 3,000 CY to less than $\$ 35 / \mathrm{CY}$ for volumes in excess of 100,000 CY. General commercial PECE for aquatic sites are 30\% higher than upland costs. Based on the demonstration projects proposed to DOE NETL for the mercury contaminated soil at Y-12, the 
fixed priced remediation costs (without soil stabilization, see discussion below) range from $\$ 370 / \mathrm{CY}$ for volumes on the order of 3,000 CY to less than \$120/CY for volumes in excess of $100,000 \mathrm{CY}$. The increased cost results from such items as potential presence of radionuclide contamination, security requirements, and reporting requirements.

The results from the NETL bench-scale testing suggest that a concentrated mercury halo may be created around the power electrode. The Team believes that with sufficient run time all the mercury accumulated at the anode face would be deposited at the power electrode.

Table 16 ECRTs-IC and Low-Temperature Thermal Desorption Cost Benefit Analysis

\begin{tabular}{|c|c|c|c|c|}
\hline \multirow[b]{2}{*}{ Cost Element } & \multicolumn{2}{|c|}{$\begin{array}{l}\text { Low-Temperature } \\
\text { Thermal Desorption }\end{array}$} & \multicolumn{2}{|c|}{ ECRTs-IC Costs } \\
\hline & $\left(\$ / C Y^{1}\right)$ & $\begin{array}{l}\text { Total Costs } \\
\text { for } 2,444 \text { CY }\end{array}$ & $(\mathbf{S} / \mathbf{C Y})$ & $\begin{array}{l}\text { Total Costs } \\
\text { for } 2,444 \text { CY }\end{array}$ \\
\hline Turn-Key Technology & $\$ 700^{\mathrm{a}}$ & $\$ 1,710,800^{\mathrm{a}}$ & $\$ 414^{\mathrm{b}}$ & $\$ 1,011,816^{\mathrm{b}}$ \\
\hline Excavation $^{2}$ & $\$ 4.78$ & $\$ 11,685$ & NA & NA \\
\hline LTTD TOTAL COSTS & $\$ 725.68$ & $\$ 1,773,559$ & NA & NA \\
\hline ECRTs-IC TOTAL COST & NA & NA & $\$ 414$ & $\$ 1,011,816$ \\
\hline
\end{tabular}

1 - Cubic Yard

2 - Estimated cost includes associated material, labor and equipment cost based on local construction costs, not including health and safety costs.

a - Based on our understanding of the baseline technology cost, excluding excavation, loading and hauling costs to landfill and disposal are not included.

b - Based on proposal cost submitted to NETL.

Table 16 presents a cost benefit analysis (CBA) between ECRTs-IC and Low-Temperature Thermal Desorption (LTTD) based on a remediation volume of 2,444 CY, the volume expected to be remediated by the Team. The assumptions used in this CBA are also identified in Table 16. As shown in the table, for a remediation volume of 2,444 CY the total cost per CY for LTTD is $\$ 725.68$ versa the cost per CY for ECRTs-IC of $\$ 414$ for the demonstration project. As the volume of material to be remediated increases (especially in a three-dimensional fashion), economies of scale come to play in ECRTs-IC's favor resulting in a significant reduction in the cost per CY as described above for general PECE.

\section{Regulatory and Other Participant Acceptance}

The technology developer and the license holder and its partners are re-introducing these technologies to the U.S. While no discussions have been held with the regulators and stakeholders interested in environmental restoration at the Oak Ridge Reservation beyond those involved in this contract, discussions have been held with numerous state and federal regulators and stakeholders involved in other ECRTs demonstration projects and through meetings and conferences where ECRTs is discussed. Table 15 presents a summary of regulatory and stakeholder activity.

The Team is not aware of any adverse commentary made relative to the deployment of ECRTs across the country. 
Table 17 ECRTs Project Activity with Participating Regulatory Agencies Identified

\begin{tabular}{|c|c|c|c|}
\hline Selected ECRTs Projects & $\begin{array}{l}\text { Participating } \\
\text { Regulatory Agency }\end{array}$ & $\begin{array}{l}\text { Stakeholders } \\
\text { Involved }\end{array}$ & Comment \\
\hline $\begin{array}{l}\mathrm{PCB}^{1} \text {-contaminated in } \\
\text { simulated soil-sediment- } \\
\text { ground water, demonstration } \\
\text { project }\end{array}$ & USEPA Region 2 & Not known & \\
\hline $\begin{array}{l}\text { CVOCs in soil and ground } \\
\text { water, demonstration project }\end{array}$ & $\begin{array}{l}\text { USEPA Region } 6 \\
\text { Local regulators } \\
\text { State regulators }\end{array}$ & $\begin{array}{l}\text { Not known, } \\
\text { addressed by } \\
\text { Principal Responsible } \\
\text { Party, WA not privy } \\
\text { to the information }\end{array}$ & \\
\hline $\begin{array}{l}\text { PAHs in fresh water sediments } \\
\text { of Lake Superior, } \\
\text { demonstration project }\end{array}$ & $\begin{array}{l}\text { USEPA GLNPO } \\
\text { Minnesota Pollution } \\
\text { Control Agency } \\
\text { USACE }{ }^{3} \text { Detroit Agency }\end{array}$ & Not known & \\
\hline $\begin{array}{l}\text { Mercury, Phenols and PAHs in } \\
\text { marine sediments of Puget } \\
\text { Sound, demonstration project }\end{array}$ & $\begin{array}{l}\text { Wash. Department of } \\
\text { Transportation, } \\
\text { Wash. Department of } \\
\text { natural Resources } \\
\text { Wash. Department of } \\
\text { Ecology } \\
\text { USEPA Site Program }\end{array}$ & $\begin{array}{l}\text { Numerous } \\
\text { stakeholders have } \\
\text { participated in the } \\
\text { approval of this } \\
\text { project; however, } \\
\text { WA not privy to the } \\
\text { information }\end{array}$ & $\begin{array}{l}\text { The contact information } \\
\text { for the Wash. } \\
\text { Department of Ecology } \\
\text { regulator involved in } \\
\text { project can be made } \\
\text { available upon request. }\end{array}$ \\
\hline $\begin{array}{l}\text { Mercury in soil, Y-12 Plant, } \\
\text { demonstration project }\end{array}$ & Unknown & $\begin{array}{l}\text { Unknown, WA not } \\
\text { privy to the } \\
\text { information }\end{array}$ & \\
\hline $\begin{array}{l}\text { Full-scale remediation of } \\
\text { diesel fuel, oil, and greases at } \\
\text { an operating bakery in Seattle, } \\
\text { Wash. }\end{array}$ & $\begin{array}{l}\text { Wash. Department of } \\
\text { Ecology }\end{array}$ & $\begin{array}{l}\text { Unknown, WA not } \\
\text { privy to the } \\
\text { information }\end{array}$ & \\
\hline
\end{tabular}

1 - Polychlorinated biphenyl

2 - Great Lakes National Program Office

3 - U.S. Army Corps of Engineers

The mercury stabilization technology owner has already developed, patented, and licensed the process for stabilizing liquid elemental mercury and wastes containing greater than $260 \mathrm{mg} / \mathrm{kg}$ of mercury used in this project. The technology is currently used by Permafix Environmental Services (Kingston, Tenn.) at their facilities in the East Tennessee Technology Park. This process will be used as is, or in slightly modified form, to treat contaminated soils and electrode solids resulting from the use of the ECRTs process.

\section{Recommendations}

The Team recommends full and immediate funding of Phase II for field demonstration of ECRTs-IC. In Phase I, the ECRTs-IC testing met the pre-defined success criteria for this phase of the contract, proving ECRTs-IC is a viable approach and more effective than EKAR. During field-scale demonstration we intend to build on the success of Phase I by deploying our system at the Y-12 National Security Complex and showing the stakeholders at the site that this technology works in the field, is effective, and offers an in situ, non-destructive method to remove mercury 
and other metals from soils and sediments. In so doing, we hope DOE and the local M\&O and M\&I contractors will consider ECRTs as a serious alternative to traditional remediation methods.

The technology owner, U.S. license holder, and their partners are very active in the commercialization of ECRTs in the U.S. and elsewhere. No technology transfer activities are planned unless meaningful sublicensing opportunities develop. Both plan to commercialize ECRTs on their own and through marketing agents and to deploy the technologies with their own company resources. Listed below are states where the technology is actively being promoted at this time.

- Maine

- Pennsylvania

- Minnesota

- Washington

- Nevada

- Texas
- New York

- North Carolina

- Wisconsin

- Oregon

- Montana

- Georgia
- New Jersey

- Tennessee

- Ohio

- California

- Idaho

- Missouri

The results of the electrode analysis revealed that there was relatively little mercury on the electrode themselves and most of the mobilized mercury was present in the soil near the electrodes. In contrast, prior field work by the Team has found substantial amounts of mercury adhered to the electrodes, so there may be site-specific factors involved. Alternatively, a longer test period may have deposited more mercury at the electrodes. Regardless, it appears that there will be a need to stabilize the electrodes and some amount of soil.

The stabilization process has already been tested on mercury-bearing soils and sludges. Adapting it to the specific Oak Ridge soil of a field trial will require small-scale treatability testing to optimize the reagent formulation. This activity would be recommended as part of a Phase II demonstration project.

The electrodes could be addressed by an acid wash of the electrode surfaces and subsequent treatment of the wash solution. This would eliminate the need to pulverize or digest the electrodes completely and this Team member has developed techniques to remove and stabilize mercury from process liquids, for example, to treat the process solution from chemical wet scrubbers. The treatment process utilizes some of the same reagents employed in the stabilization process discussed above. Testing and, if necessary, treatment of the recovered electrodes is also a recommendation for any Phase II demonstration project.

\section{Changes to the Phase II Scope of Work}

Based on the results of the Phase 1 bench-scale test on Y-12 mercury contaminated soils, the Team would like to make the following recommendations.

$>$ Ideally, perform the ECRTs-IC pilot demonstration in the same area from which the soils tested in Phase 1 where collected. 
The mercury speciation should be tracked during the ECRTs-IC remediation. If this recommendation is accepted, then mercury speciation data must be collected:

o prior to the onset of remediation to characterize the mercury species present under baseline conditions;

o concurrent with the ECRTs-IC remediation process; and,

o post-ECRTs-IC remediation shutdown. 


\section{References}

1. Doering, F., 1994, "Verfahren und Einrichtung zur Beseitigung von Schadstoffen, insbesondere im Erdbodenbereich” European Union Patent No. 0578925 A1.

2. Doering, F., 1996, "Verfahren zur Abtoetung von Mikrooganismen und/oder Mineralisierung von Oganischen Substanzen im Boden und im Groundwasser mittens elektrischen Stromes” European Union Patent No. EP 0729796 A1.

3. Doering, F., 1997, "Method and Device for the Elimination of Toxic Materials from, in Particular, the Topsoil” United States Patent No. 5,595,644.

4. Doering, F., 1998, "Method Related to the Sterilization of Microorganisms and/or to the Mineralization of Organic Substances Including Microbic Metabolites in a Ground Region and in the Ground Water by means of Electric Current”, United States Patent No. 5,738,778.

5. von Hipple, A. R., 1954a, Dielectrics and Waves, The M.I.T. Press, Cambridge.

6. von Hipple, A. R., ed. 1954b, Dielectric Materials and Applications, The M.I.T. Press, Cambridge.

7. Hill, D. G., 1972, “A Laboratory Investigation of Electrical Anisotropy in Precambrian Rocks”, Geophysics, v. 37, No. 6 (December), pp. 1022 - 1038.

8. Keller, G. V., and Licastro, P. H., 1959, "Dielectric Constant and Electrical Resistivity of Natural -State Cores", U.S. geological Survey Bulletin 1083-D, pp. $111-129$.

9. Schlumberger, C., 1920, “Étude sur la prospection électrique du sous-sol”, Gauthier-Villars, Paris.

10. Vacquier, V., Holmes, C. R., Kintzinger, P. R., Lavergene, M., 1957, "Prospecting for Ground Water by Induced Electrical Polarization”, Geophysics, v. 22, No. 3 (July), pp. 660 - 687.

11. Zonge, K. L., and Wynn, J. C., 1975, "Recent Advances and Applications in Complex Resistivity Measurement”, Geophysics, v. 40, No. 5 (October), pp. 851 864

12. Probstein, R. F., Renaud, P. C., and Shapiro, A. P., 1991, "Electroosmosis Techniques for Removing Materials from Soil”, U.S. Patent No. 5,074,986. 


\section{List of Acronyms and Abbreviations}

\begin{tabular}{|c|c|c|c|}
\hline BJC & Bechtel Jacobs Corporation & S\&HP & Safety and Health Plan \\
\hline CA & characterization areas & TCLP & Toxicity Characteristic Leaching \\
\hline CBA & cost benefit analysis & & Procedure \\
\hline DC & direct current & UEFPC & Upper East Fork of Poplar Creek \\
\hline d.m. & dry mass & USACE & U.S. Army Corps of Engineers \\
\hline DOE & U.S. Department of Energy & USEPA & U.S. Environmental Protection \\
\hline \multirow[t]{2}{*}{ ECRTs } & ElectroChemical Remediation & & Agency \\
\hline & Technologies & UTS & Universal Treatment Standard \\
\hline \multirow[t]{2}{*}{ ECRTs-ECGO } & ECRTs-ElectroChemical & VAC & Volts alternating current \\
\hline & GeoOxidation & VDC & Volts direct current \\
\hline EKAR & electrokinetic aided remediation & Y-12 & U.S. Department of Energy Y-12 \\
\hline EKR & electrokinetic remediation & & National Security Complex \\
\hline ECPRA & $\begin{array}{l}\text { Emergency Planning and } \\
\text { Community Right-to-Know Act }\end{array}$ & & \\
\hline EPP & $\begin{array}{l}\text { Environmental Protection } \\
\text { Program }\end{array}$ & & \\
\hline ES\&H & Environmental, Safety \& Health & & \\
\hline GLNPO & $\begin{array}{l}\text { Great Lakes National Program } \\
\text { Office }\end{array}$ & & \\
\hline IC & Induced Complexation & & \\
\hline LTTD & $\begin{array}{l}\text { Low-Temperature Thermal } \\
\text { Desorption }\end{array}$ & & \\
\hline M\&I & management and integration & & \\
\hline $\mathrm{M} \& \mathrm{O}$ & management and operation & & \\
\hline MSDS & material safety data sheets & & \\
\hline NEPA & National Environmental Policy & & \\
\hline \multicolumn{4}{|l|}{ Act } \\
\hline NETL & $\begin{array}{l}\text { National Energy Technology } \\
\text { Laboratory }\end{array}$ & & \\
\hline ORR & Oak Ridge Reservation & & \\
\hline PAH & $\begin{array}{l}\text { Polycyclic Aromatic } \\
\text { Hydrocarbon }\end{array}$ & & \\
\hline PCB & polychlorinated biphenyl & & \\
\hline PECE & $\begin{array}{l}\text { Preliminary Engineering Cost } \\
\text { Estimates }\end{array}$ & & \\
\hline PPA & Pollution Prevention Act & & \\
\hline PPE & personal protective equipment & & \\
\hline PRDA & Program Research \& & & \\
\hline QA & $\begin{array}{l}\text { Development Announcement } \\
\text { Ouality Assurance }\end{array}$ & & \\
\hline QAPP & Quality Assurance Project Plan & & \\
\hline RCRA & Resource Conservation and & & \\
\hline RFP & $\begin{array}{l}\text { Recovery Act } \\
\text { request for proposal }\end{array}$ & & \\
\hline
\end{tabular}




\section{APPENDIX}

Laboratory Working Copy of Final Work Plan

\section{Demonstration of ElectroChemical Remediation Technology}

Prepared by

ADA Technologies, Inc. in cooperation with Weiss Associates and TPG Applied Technology

Prepared for

US Department of Energy under Contract DE-AC26-

$01 N T 41346$

January 16, 2002 


\section{Table of Contents}

1. Project and Technology Description ................................................................................................. 1

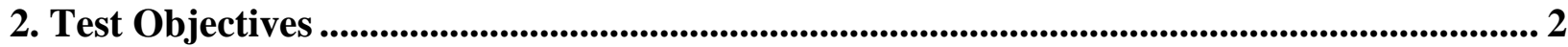

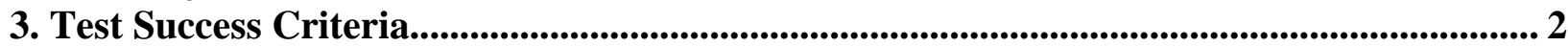

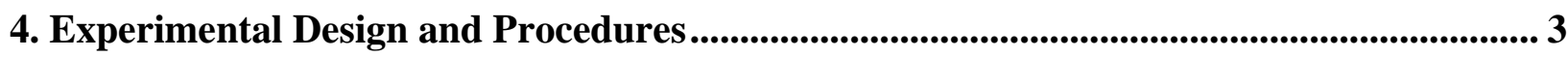

4(a) Experimental Design ...........................................................................................................3

4(b) Experimental Procedures .............................................................................................................4

5. Sample Preparation, Equipment and Materials ................................................................. 4

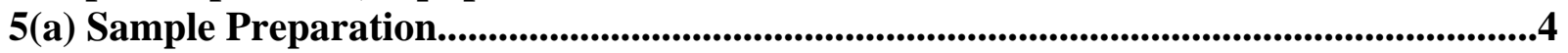

5(b) Design of ECRT-IC Test Cell.....................................................................................5

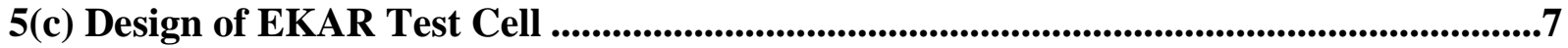

6. Sampling and Analysis Plan................................................................................................ 8

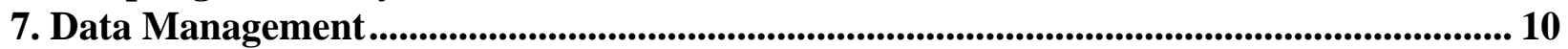

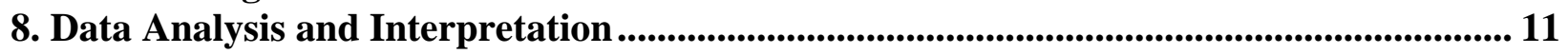

9. Environmental, Safety and Health Plan .................................................................... 11

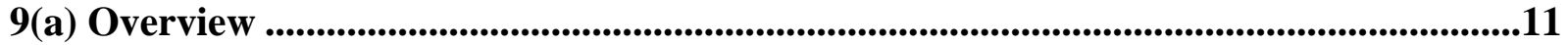

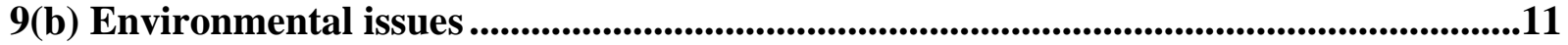

9(c) Safety Issues ......................................................................................................................12

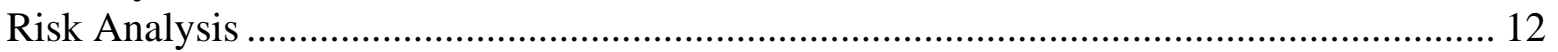

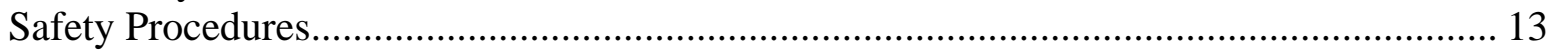

9(d) Health Issues ........................................................................................................................13

10. Waste Management and Decontamination.................................................................. 14

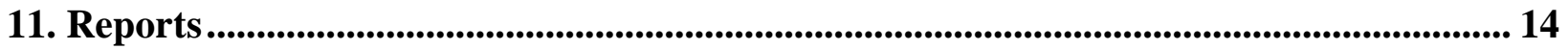

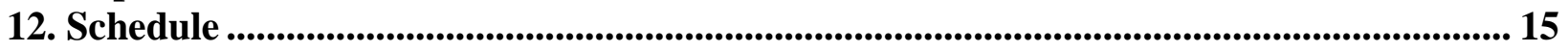

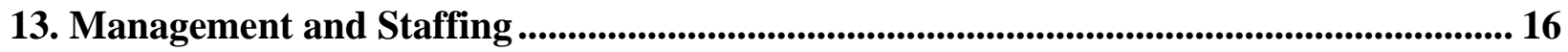

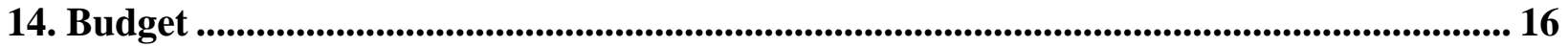

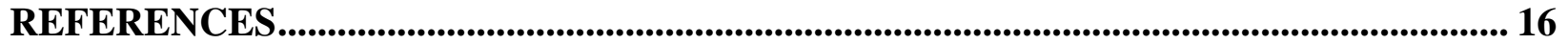




\section{Project and Technology Description}

After nearly sixty years of designing, manufacturing, and testing nuclear weapons, the U.S. Department of Energy (DOE) is faced with the challenge of cleaning up the hazardous waste left behind. More than 5,700 known DOE groundwater plumes have contaminated more than 475 billion gallons of water. DOE landfills contain more than 3 million cubic meters of buried waste contaminating the surrounding environment. At DOE sites throughout the country, soil, groundwater, and landfills containing or contaminated with hazardous and radioactive constituents have special cleanup needs. This project is directed at application of in-situ technology to remove mercury contamination in the subsurface environment, and also addresses other metals of concern and radionuclides that may be present as co-contaminants. Mercury contamination is found at many DOE sites with the largest problems identified at the Savannah River Site and the Oak Ridge, Tenn., Y-12 Nuclear Weapons Facility (Y-12). Mercury was utilized during the 1950s and early 1960s to separate lithium isotopes for the manufacture of nuclear weapons at these sites. At Y-12 remedial actions are planned that include excavation and disposal of 300,000 cubic yards of soil and sediment contaminated with mercury, other heavy metals, and radionuclides (primarily uranium). It is currently estimated that up to 50,000 cubic yards of material will be classified as Resource Conservation and Recovery Act (RCRA) wastes due to the presence of mercury and other heavy metals.

This project is a two-phase study that will focus on removal of mercury and other metals along with uranium and other radionuclides from contaminated soils to reach specified treatment goals. The TPG Team will test and demonstrate a patented technology for in-situ treatment of soils and debris, ElectroChemical Remediation Technologies/Induced Complexation (ECRT/IC), along with patent-pending technology for stabilization of mercury treatment residuals and wastewater contaminated with mercury.

For in-situ technologies one or more of the treatment goals noted below must be met:

.1 Mercury content in treated soil less than the Toxicity Characteristic Leaching

Procedure (TCLP) level for mercury $(0.2 \mathrm{mg} / \mathrm{L}$ in TCLP leachate)

.2 Mercury content of ten times the UTS $(0.25 \mathrm{mg} / \mathrm{L})$ in TCLP leachate

If DOE decides to proceed with Phase II, these goals will be applied in a field pilot test. Phase I success standards will be discussed later in this document.

The proposed treatment process (ECRT/IC) will be first evaluated in bench scale tests to be conducted at Hazen Research located in Golden, Colo. After demonstration of the feasibility and advantages of the process, a pilot scale demonstration of the technology will be performed in Phase II at a site in Oak Ridge, TN chosen by the DOE.

This Work Plan addresses only the activities in the bench scale tests conducted in Phase I of the project. During Phase I a sample of mercury-contaminated soil obtained from a site in Oak Ridge, TN will be treated with the technology of interest: Electro-Chemical Remediation Technology Induced Complexation (ECRT/IC). A baseline test utilizing the Simplified Probstein Patent, et al. (1991), Electrokinetic Aided Remediation (EKAR) patented technology will also be run for comparison. The tests will be performed by ADA Technologies, Inc. under the direction of Weiss Associates. The testing will be performed at Hazen Research in Golden, CO. The Hazen facilities are fully compliant with all ESH\&R requirements for hazardous and radioactive materials such as the samples to be obtained from Oak Ridge. The bench-scale tests will be 
performed in nonconducting cells (similar in size and configuration to fish aquariums) containing approximately 150 liters of soil sample.

ECRT-IC is an in-situ environmental remediation technology. Electrical energy is introduced into the soil, from a proprietary AC/DC power converter, which charges and discharges polarization sites, distributed throughout the soil. This charging and discharging of the polarization sites provides the energy needed to mobilize metallic contaminants for removal.

The ECRT-IC phenomenon is related to pore scale electrochemistry and belongs to the class of Direct Current Technologies (DCT) where direct current electricity is passed between two subsurface power electrodes. ECRT generates oxidation-reduction (ReDox) reactions at the pore scale, mineralizing organic contaminants through the process of ElectroChemical GeoOxidation, (ECGO) to their inorganic constituents and significantly enhancing the mobilization of metals through the process of IC.

The baseline comparison technology of the Simplified Probstein, et al., (1991) patented EKAR technology will be performed, using a low-ripple DC power supply. EKAR involves the mechanisms of (1) electro-osmosis, (2) electro-migration, (3) electrophoresis, (4) electrolysis, and (5) joule heating. The first three EKAR mechanisms cause increased transport of water, contaminants, and/or nutrients. Electrolysis involves the decomposition of water to oxygen and hydrogen; this is also referred to as water hydrolysis. Joule heating is electrical resistance heating of the soil and/or ground water.

\section{Test Objectives}

The purpose of the laboratory testing of the ECRT-IC process is to demonstrate that mercury contained in the soil sample migrates to one or both of the process electrodes when the technique is applied.

The intent of the Phase I testing is neither to provide scale-up criteria nor to provide absolute values for remediation effectiveness via this process. Laboratory testing of ECRT-IC is a significant challenge because the process works most effectively with low system resistance, voltage gradients, and current densities found only in actual field systems. Laboratory test cell dimensions prevent achievement of these electrical conditions, for the same soils and waters, which allow them in the field. This geometric limitation may be overcome by using chemically benign (largely non-reacting) electrolyte solution brines to reduce the test cell resistance to be equivalent to the resistances seen by ECRT IC power converters in the field.

The specific objectives for Phase 1 are therefore:

\section{Demonstrate the mobility of mercury afforded through the use of ECRT-IC, and}

\section{Demonstrate that mercury is plated on the electrodes when a soil sample is subjected to ECRT-IC. A secondary objective is to characterize the mercury found on the electrodes with regard to TCLP and to show the ability to stabilize the mercury on the electrodes.}

\section{Test Success Criteria}

Data collected during operation of the test cells during Phase I will provide the basis for judging the success of the test program. As indicated in Section 2, the ECRT-IC process is difficult to 
scale down for laboratory evaluation. For this reason the Phase I success criteria are different from those one would specify for a field scale demonstration.

1. Mobilization of Hg to both electrodes (yes/no criterion): This will be determined by the analysis of mercury concentration in the soil sample measured as a function of time and position in the test cell. We will look for decreases in the mercury concentrations at sample locations in the test cell as a function of time. This will also be verified by characterization of the electrodes at the end of the test run to identify the presence of mercury. Analyses will track soluble, elemental, and total mercury in the soil samples.

2. Hg mobilization rate: As in the above item, this will be determined by analysis of mercury concentration in soil samples measured as a function of elapsed test time and position in the test cell. The target mobilization rate is $3.3 \mathrm{~g} \mathrm{Hg}^{+2} / \mathrm{amp}$-hour of operation.

3. Increased rate of mobilization for Hg using ECRT-IC versus EKAR. This will be determined from the same set of soil mercury measurements utilized in item 2 . The success criterion will be that the ECRT-IC-induced reduction in mercury concentration in cell measurements exceeds that for the EKAR process.

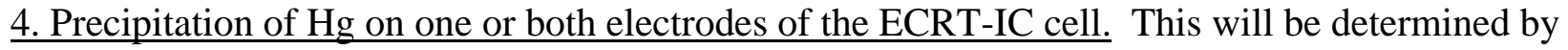
analysis of the electrodes at the end of the test. The ECRT-IC electrodes will be sectioned and analyzed for the presence of mercury.

$\underline{5}$. Stabilization of Hg that is deposited on the electrodes. The ability to stabilize the mercury deposited on the ECRT-IC electrodes is critical to cost-effective operation of the process. A simple process to stabilize the collected mercury as either an amalgam or mercury compound (such as mercuric sulfide) will be performed, and a TCLP test will be run on the stabilized residue to confirm sequestration of the mercury.

6. Removal of mercury from the test soil to the level dictated in the RFP. This was specified as either:

(i) less than the Toxicity Characteristic Level for mercury ( $0.2 \mathrm{mg} / \mathrm{L}$ in TCLP leachate), or

(ii) ten (10) times the Universal Treatment Standard of $0.025 \mathrm{mg} / \mathrm{L}$ or $0.25 \mathrm{mg} / \mathrm{L}$ in the TCLP leachate.

\section{Experimental Design and Procedures}

\section{4(a) Experimental Design}

One test cell will be constructed to demonstrate the performance of Electro-Chemical Remediation Technology-Induced Complexation (ECRT-IC). A second test cell will utilize the Simplified Probstein, et al., (1991) patented Electro-Kinetic Aided Remediation technology (EKAR), as a baseline. It will be necessary in the design of the ECRT-IC test cell to address the technical problems (e.g. resistance) associated with a bench scale demonstration of a technology designed for implementation using very large electrodes at a much larger field scale. Therefore, an electrolyte may be used to reduce the overall resistance of the soil sample in the cell.

The demonstration will use two identical cells separately configured for each of the two techniques, each containing approximately 150 liters of homogenized, mercury-contaminated soil from the Oak Ridge site. The cells will run in parallel and the operating parameters of 
voltage, current and temperature will be monitored digitally using a Campbell data logger at 5 minute intervals and manually at appropriate intervals.

The contaminated soils in the cells will be sampled at the start, estimated mid-point and close of the demonstration for speciated mercury, $\alpha, \beta$ and $\gamma$ radioactivity (if appropriate), $\mathrm{pH}$, conductivity and RCRA heavy metals. The metals transported from the soils in the EKAR test cell will be transferred to external ion exchange traps. These traps will be also be analyzed at the start, mid-point and end of the demonstration.

The appropriate applied voltage for the EKAR cell and electrolyte concentration for the ECRTIC cell will be determined in preliminary trials using uncontaminated soils. This will limit the amount of contaminated waste that is generated and also minimize the risk of modifying the properties of the sample in tuning the process to achieve optimum performance.

\section{4(b) Experimental Procedures}

Once the correct concentration of the electrolyte in the ECRT-IC cell and the voltage to be applied to the EKAR cell have been defined, the two cells will be filled with equal quantities of the homogenized Oak Ridge soil sample. The aqueous phase will be added and the cells left to settle for at least 2 hours. Baseline samples will be collected according to the procedures described in Section 6. The pumping system for the EKAR cell will be operated and leakchecked.

Power supply will be initiated and data recording started. The temperatures, voltages and currents will be recorded digitally (see section 7) but the cells will be continuously monitored manually during the first 8 hours of operation, to ensure that there are no unplanned excursions of these important parameters. In the event of any inappropriate excursions, the power supply will be interrupted, the data evaluated and an appropriate response prepared. However, it is expected that preliminary test runs with uncontaminated soils will reduce the likelihood of unforeseen eventualities to a very low probability.

After the tests have achieved stable operating conditions, the cells will be monitored manually by Hazen operators at two hour intervals during the day. In addition, the data logger will also be attached to a modem that will allow ADA or WA staff to monitor the experimental conditions remotely.

It is assumed that the 150 liters of soil will contain up to approximately 6,000 ppm mercury, yielding an estimated total of up to approximately 1,620 g of elemental mercury in the cell.

\section{Sample Preparation, Equipment and Materials}

\section{5(a) Sample Preparation}

It is anticipated that the 300-liter sample of mercury-contaminated soils from OR will be shipped as 15-20 five-gallon buckets. In view of its provenance, it is essential to determine the level of radioactivity in each bucket immediately upon arrival at Hazen. Therefore, each bucket will be tested for total radioactivity externally, prior to opening. The lid will then be partially opened and the soil will again be tested using a survey meter. If radioactivity is above de minimis levels, standard radiological handling procedures will be implemented.

The material from each bucket will be sieved to $1 / 4$ " before proceeding to the sample homogenization step, as particles significantly larger than this will interfere with sampling and 
the (reduced scale) electrochemical processes. Agglomerates larger than $1 / 4$ " will be broken on the screen if possible, otherwise the material will be rejected and saved.

It is not known if all of the sample will come from a single site, or whether it has been homogenized. However, for the purposes of this demonstration it will be assumed that the sample will include significant inhomogeneities. Therefore, the entire sample will be transferred to a large mortar mixer and tumbled for a minimum of one hour. If there are visible differences between the contents of the different buckets, the mixing will be continued until there are no visible differences in the material in the mixer and the mixing will then be continued for an additional period equivalent to at least three times the original time. However, under no circumstances will the mixing period be less than one hour.

The material in the mixer will then be sampled from five separate locations and the mixer will be sealed with tape and plastic while the samples are analyzed (after acid digestion) for their total mercury content using cold vapor atomic absorption spectrometry. It is recognized that perfect homogeneity is difficult to achieve in such a large sample and, therefore, the target will be for the analyses to all fall within a range of $\pm 15 \%$. If this target is not achieved, the mixing and sampling program will continue until it is. If there is a large range of particle sizes in the soil, the sub-samples will be ground to -40 mesh prior to analysis.

After the sample has achieved the target level of homogeneity, equal quantities will be transferred to each of the test cells.

\section{5(b) Design of ECRT-IC Test Cell}

The ECRT/IC Tests will utilize the technology of the Döring (1993, 1996, 1997, and 1998) patents. The test cell will be housed in a non-conductive tank, with the approximate dimensions of 90Lx50Wx45D (cm), to accommodate the 150 liter sample, constructed from either heavy gauge plastic or glass (Figure 1). The joints will be glued, or in the case of a plastic bath, it will be of monolithic construction, as it is essential to avoid metal edges or corners in the construction to prevent current leakage from the test cell interior and by-pass of the sample material.

The test cell will be fitted with two electrodes each with a surface area of approximately 2,500 $\mathrm{cm}^{2}$. A sheet of UCAR graphite (grade CS), approximately $0.9 \mathrm{~cm}$ thick will be used as the anode for the cell, and a sheet of carbon steel, approximately $0.1 \mathrm{~cm}$ in thickness, but of the same surface area, will act as the cathode. The two electrodes will be weighed and thicknesses measured, with a micrometer, prior to mounting on the inner surfaces of the two long faces of the bath. The electrodes will be isolated from the wall material of the bath by non-conductive plastic spacers, approximately $1 \mathrm{~cm}$ in thickness. The electrodes will be mounted such that they lie directly opposite each other in the bath, in a position that will place the upper edges approximately $2 \mathrm{~cm}$ below the surface of the sample, when the cell is filled.

A lid, to prevent evaporation changing the conditions of the experiment during the period of the test, will cover the cell. This is required because of the over 5,000 ft elevation and wintertime low humidity of the test location.

The electrodes will be connected to a specialized AC/DC converter (110 VAC input, adjustable $\approx 170$ VDC max, 5 A output). The electrodes will be connected to the power supply by insulated copper leads. The leads will be attached to the electrodes using stainless steel nuts, bolts and washers at the cathode and nylon nuts, bolts and washers at the anode. The circuit will also 


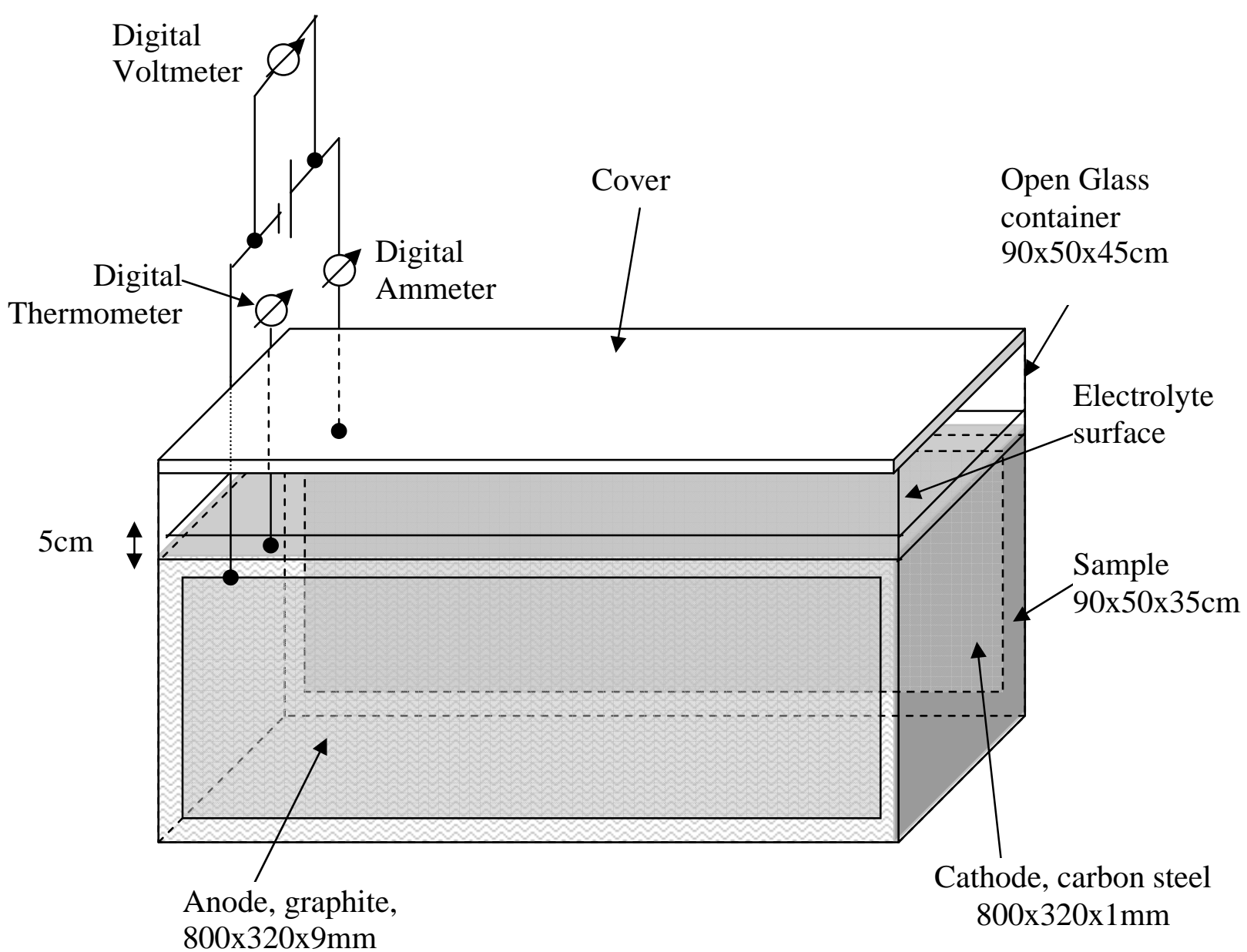

Figure 1. Schematic of ECRT-IC test cell

incorporate a digital voltmeter and a digital ammeter. A digital thermometer will be inserted into the sample and the temperature monitored to ensure that the experimental conditions remain constant.

Approximately 150 liters of the homogenized sample will be introduced into the cell. Depending on the electrical properties of the soil a solution of an electrolyte may be added; otherwise water will be used. The use of an electrolyte may be required to reduce the resistance of the cell, which could be unacceptably high due to the relatively small dimensions of the power electrode array, as compared to a typical field installation.

If used, the electrolyte will be a chemically benign salt, such as sodium sulfate, or sodium chloride, dissolved in deionized water. The objective will be to create a cell with a total resistance of approximately $10 \Omega$, to give a current of 1-2 amps under an EMF of 10 volts. The concentration of the salt will be calculated based on literature values for the specific conductance of the solution and the surface areas and spacing of the electrodes. However, it will be difficult to predict the effect the presence of the soil between the electrodes and any polarization effects that may occur at the electrodes. Therefore, to avoid the risk of generating large quantities of contaminated solutions, a test will be completed with an uncontaminated soil to determine the 
optimal salt concentration in the electrolyte prior to filling the cell with the mercurycontaminated Oak Ridge soil.

\section{5(c) Design of EKAR Test Cell}

The EKAR tests will utilize the Simplified Probstein, et al. (1991) patented technology. The test cell will be constructed identical to the ECRT-IC test cell, with the following exceptions:

1. The DC power supply will be a commercially available low ripple 480 VAC input, with minimum $0-170$ VDC, 0 - 5 A DC output.

2. Both of the EKAR power electrodes will be constructed from stainless steel (316-L).

3. The power electrodes will be isolated from direct contact with the sample by a surrounding enclosure constructed from a semi-permeable membrane, supported by a non-conductive screen mesh (Figure 2).

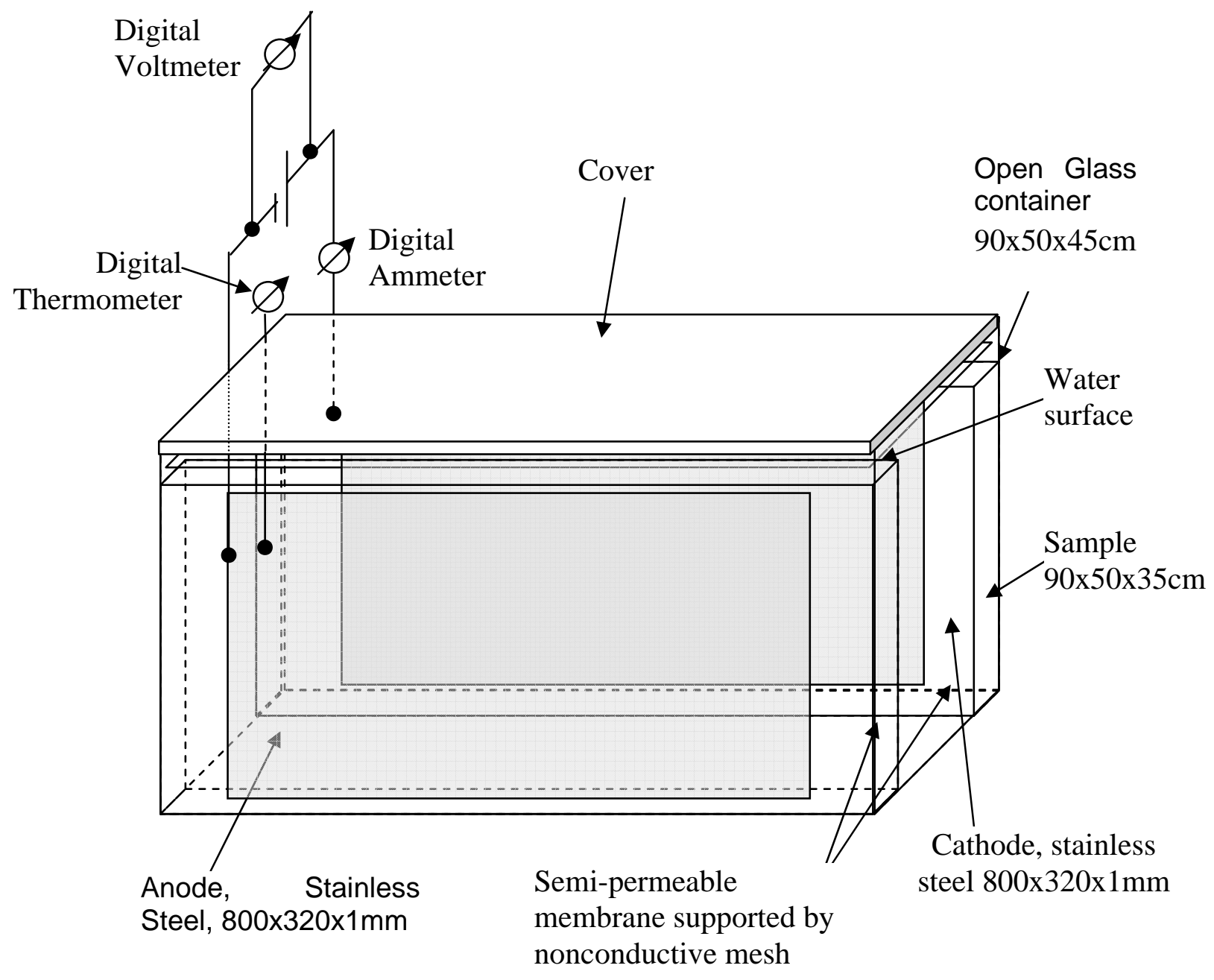

Figure 2. Schematic of the EKAR Test Cell 
4. The electrode enclosures and the EKAR cell will be filled with tap water. The water in the electrode enclosures will be pumped in constant circulation through external ion exchange beds (separate exchange bed circuits for each electrode), to accumulate mercury and other ions as they pass from the sample to the electrodes through the semi-permeable membranes, as the experiment proceeds. The purpose of the semipermeable membranes is to prevent solids fouling of the electrode baths and the ion exchange columns.

A schematic of the electrode flush circulation system is presented in Figure 3. Other features of the EKAR cell, including the digital meters, and the thermometer will be identical to those to be used in the ECRT-IC test cell.

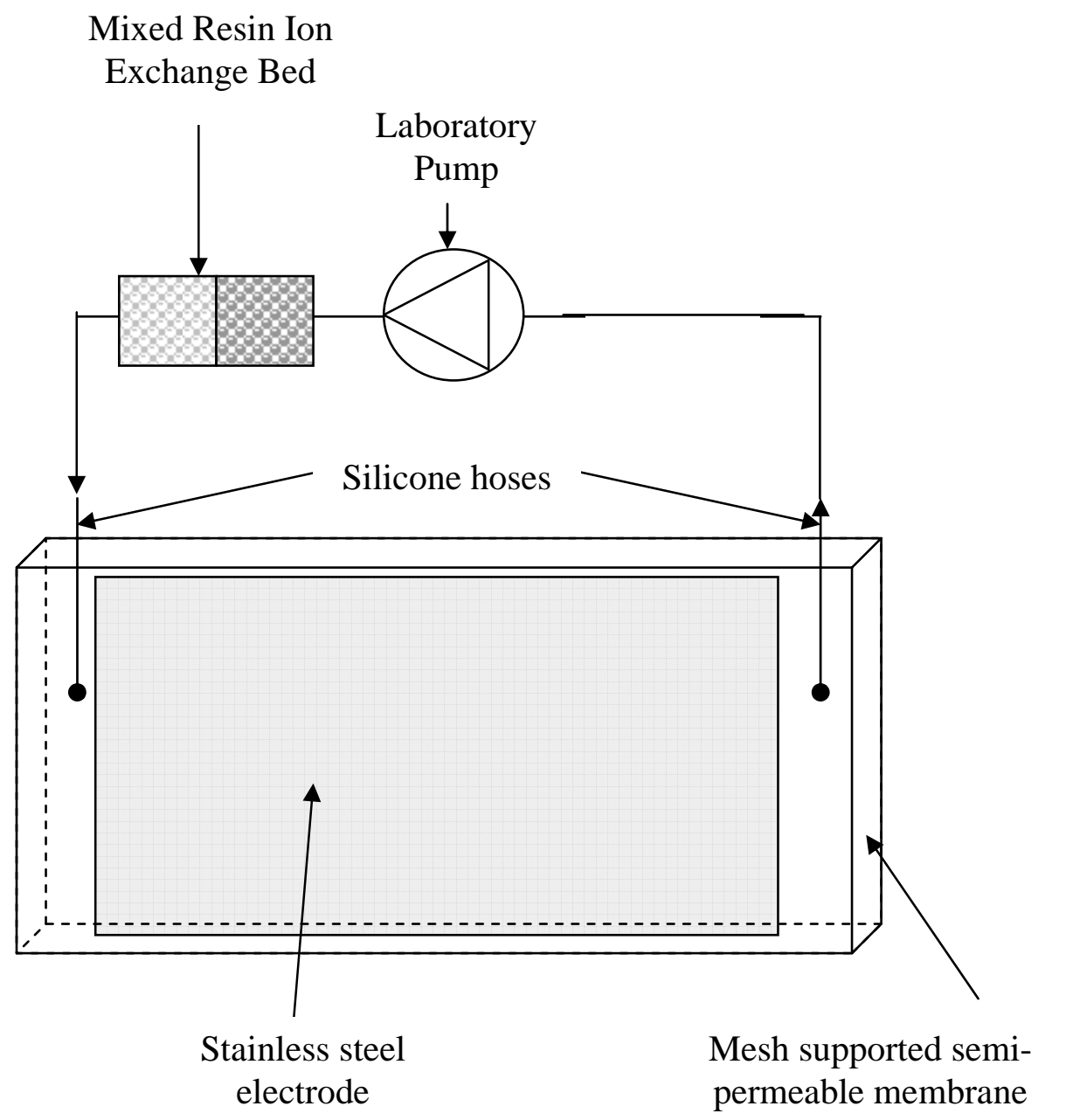

Figure 3. Schematic of the EKAR Electrode Flushing System

\section{Sampling and Analysis Plan}

The sampling of the raw material to ensure homogeneity is described in Section 5(a). Once the appropriate level of precision has been achieved, based upon the analysis for total mercury, the aqua regia digests will be analyzed for the metals zinc, cadmium, copper, lead, silver, iron, 
arsenic, selenium and uranium using inductively coupled argon plasma atomic emission spectrometry or equivalent methods commonly used by Hazen. Arsenic and selenium will be determined using hydride generation.

Five additional samples will be collected from the bulk sample and subsets will be analyzed for speciated mercury using the scheme detailed in Table below.

The replicate aqua regia digestions will provide an additional level of assurance of the homogeneity of the bulk sample. The soil samples will also be analyzed for conductivity and $\mathrm{pH}$ and major anions using ion chromatography. In addition to the analysis of the soils, the tap water used in the EKAR cell will be analyzed for $\mathrm{pH}$, conductivity, total dissolved solids and anions.

Table 1 Analytical scheme for speciated mercury

\begin{tabular}{|c|c|}
\hline Extraction Method & Target Species \\
\hline Deionized Water & Soluble mercury $\left(\mathrm{Hg}^{+}\right.$and $\left.\mathrm{Hg}^{++}\right)$ \\
\hline Dilute Nitric Acid & Elemental plus oxidized mercury \\
\hline Aqua regia & Total mercury \\
\hline
\end{tabular}

At the beginning of the tests, after the soils and aqueous phases have been allowed to equilibrate, but before the power is turned on, five samples will be collected from across the width of the cell between the two electrodes. The samples will be collected using a sampling "thief" to collect material from approximately the mid-level of the cell, without causing too much disturbance of the sample. The sampling device, also known as a Coliwasa, allows for collection of wet solids from a selected soil depth. The samples will be subjected to the same analytical scheme as the original material. The samples will be weighed and then dried to determine the concentration of solid material. The surface liquid layer will also be sampled and analyzed for total mercury.

Based on estimates of the rate of accumulation of mercury at the electrodes of the ECRT-IC cell, a further set of samples will be collected from the cells at specified time intervals, again repeating the same analytical scheme.

The mercury and other mobilized ions in the EKAR cell will accumulate in the external ion exchange cells. The raw resin will be analyzed prior to loading the cells and the entire contents of the ion-exchange cells will be replaced with fresh resin at the mid-point in the estimated total operating time for the demonstration. The resin will be digested and analyzed for mercury and iron.

The monitoring of mercury concentrations in the soils at the cell mid-point will allow a more accurate estimation of the end-point of the demonstration. A third set of samples will be collected at the predicted completion time and the power will be turned off.

At this point, the electrodes will be carefully withdrawn from the ECRT-IC cell, and a set of samples collected from top, middle and bottom of the soil beds in the cells at the sites of the electrodes. These samples will be analyzed for speciated mercury and iron. 
It is anticipated that both of the ECRT-IC electrodes will be covered by a film of elemental mercury. Past experience has suggested that this mercury film will be well-adhered to the electrode, but they must be carefully handled. The electrodes will be rinsed of any soil material, dried, weighed, and thickness measured at the same locations used for the pre-test measurements.

The electrodes will then be cut into sixteen approximately equal-area sections and each section weighed. Two widely separated sections of each electrode will be digested in aqua regia and analyzed for total mercury. Two other widely separate sections will be cut into smaller pieces ( $<$ $9.5 \mathrm{~mm}$ ) and analyzed by the TCLP procedure for extractable mercury.

The remaining twelve pieces will be separated into four groups of three, for each electrode. The mercury on these sub-sets will be stabilized using ADA's proprietary stabilization methods and tested using the TCLP procedure. Additional detail regarding the sampling plan can be found in Appendix B.

It must be emphasized that the objective of this project is to demonstrate ECRT-IC Technology. The EKAR test cell is included only for comparison. Therefore the end point of the experiment will be determined solely by the behavior of the mercury in the ECRT-IC cell and the demonstration will end based upon the analysis of mercury in this cell, irrespective of the residual concentrations in the EKAR cell.

\section{Data Management}

Data will be generated during phase 1 of the project by several mechanisms. These are summarized in the following table.

\begin{tabular}{|l|l|}
\hline \multicolumn{1}{|c|}{ Parameter(s) } & \multicolumn{1}{c|}{ Recording Method } \\
\hline $\begin{array}{l}\text { Notes regarding equipment setup, } \\
\text { operations, and experiment chronology }\end{array}$ & $\begin{array}{l}\text { Manually recorded in ADA registered log } \\
\text { book }\end{array}$ \\
\hline Cell temperature, voltage, and current & $\begin{array}{l}\text { Automatically recorded on Campbell data } \\
\text { logger }\end{array}$ \\
\hline Aqueous pH, conductivity, ORP & $\begin{array}{l}\text { Manually recorded in ADA registered log } \\
\text { book }\end{array}$ \\
\hline Soil sample analyses & $\begin{array}{l}\text { Hard copy reports from Hazen analytical } \\
\text { chemistry laboratory }\end{array}$ \\
\hline
\end{tabular}

All numerical data will be input to Excel spreadsheets for ultimate reduction and reporting in the monthly and final project reports. The data files from the Campbell data logger and all of the Excel spreadsheets will be stored electronically on the ADA Technologies, Inc. local area network (LAN). The LAN is subject to daily tape backup; the ADA LAN is also backed up to tape on a monthly basis and the resulting tape is stored at a secure off-site location. A photograph file will be maintained throughout the project to document the experimental setup, operations such as initial soil homogenization and sampling, initial and final condition of the electrodes, and any unusual findings. The photographs will be taken with one of the ADA digital 
cameras. Hard copy of the photographs will be inserted into the project log book and electronic copies will be maintained on the ADA LAN.

\section{Data Analysis and Interpretation}

Data analysis and interpretation will be performed in conjunction with Weiss Associates and TPG. The ultimate goals of the effort is to enable a mass balance in regard to mercury and any radionuclides that are present, to document process parameters during operation and document the characteristics of the electrodes at the end of the demonstration cycle. As noted above all numerical data will be entered into excel spreadsheets. The spreadsheets will facilitate mass balance determination as well as data trend analysis. During the operation of the equipment the spreadsheets will be updated on a weekly basis. The data will be reviewed by the TPG/Weiss/ADA team for quality as well as internal consistency. Plots of operating parameters (temperature, voltage, current) will be maintained. As soil sample analyses become available plots of mercury (other metals and radionuclides (if appropriate)) concentration as a function of time and location will be prepared from the spreadsheets. These data will enable the determination of transport rate and will help guide the demonstration in regard to termination. Plots of $\mathrm{pH}$, conductivity, and ORP will also be maintained to aid in assessment of demonstration stability as well as progress.

As described in Section 6 the ECRT electrodes will be thoroughly analyzed at the end of the demonstration. These data will also be placed in an Excel spreadsheet for analysis, reporting, and safe storage purposes.

At the end of the demonstration all collected data will be consolidated into tables and figures to facilitate preparation of the project final report.

\section{Environmental, Safety and Health Plan}

\section{9(a) Overview}

The experiments outlined and detailed in this work plan will be carried out in a laboratory at Hazen Research in Golden, Colorado under the direction of project personnel. Detailed descriptions of the experiments are provided earlier in this document. Since the planned work is to be carried out in a laboratory, environmental issues consist of delivery and handling of contaminated soil samples to be used in testing, disposal of treated wastes upon completion of the experiments, and follow-up handling of the mercury-contaminated electrodes generated in the lab experiments. Standard laboratory procedures will be implemented for safety and health of technicians and engineers participating in the experiments. The primary safety issue is the use of an electric field in the test cells, and is discussed in greater detail in this section. The health issues focus around handling of the materials to be provided by DOE and used in the planned experiments. These materials will contain mercury contamination and may be radioactive. The host facility at Hazen Research is licensed to handle such materials, and its engineers and technicians have appropriate training for environmental, safety and health aspects of the planned experiments.

\section{9(b) Environmental issues}

The Department of Energy will ship to the test laboratory at Hazen Research approximately 540 $\mathrm{kg}$ of mercury-contaminated soil for use in the experiments. All appropriate precautions will be 
undertaken with this material that will be shipped and handled as a hazardous mixed waste. After completion of the experiments, the treated material will be returned to ORNL along with the contaminated electrodes from the treatment process and any experimental components or other waste materials that become contaminated in the performance of the tests. Hazen Research is licensed to handle the test material and also has appropriate shipping permits to package, label and release the material for return shipment to ORNL.

For the entire treatment time of the experiments, the test cells will be situated in laboratory hoods with controlled ventilation flow that is filtered to capture any mercury vapor or radioactive gas emissions that may be released. The test cells themselves will be covered to minimize the potential for emissions. Technicians and project engineering personnel will be present in the testing laboratory only when necessary. The ventilation hood filters will be changed out upon completion of the experiments and checked to determine if they must be handled as rad waste.

There is one procedure that will require some additional attention to environmental confinement. Upon arrival, the test material will be loaded into a mortar mixer to be homogenized and sampled for characterization. The loaded mixer will be operated for a period of one hour or more to assure that the material is as uniform as possible in mercury content and particle size distribution before being loaded into the test cells. The mixer will be connected to a filtered vent to minimize worker exposure to mercury and/or radioactive gases during the mixing. The technician conducting this operation will wear disposable coveralls and a respirator to minimize the potential for exposure to mercury or radioactive waste during the process.

\section{9(c) Safety Issues}

An Activity Hazards Analysis was completed for the bench-scale testing and is required reading for all project personnel involved in the testing. As noted earlier, the primary safety concern in the planned experiments is the use of an electrical current to drive the in-situ mercury removal process. As a result of this concern, a risk analysis was performed for the electrical operation of the test cells, with results presented below.

\section{Risk Analysis}

While electricity is the prime motive force in the planned demonstrations, electrical hazards can be avoided with simple planning and the use of standard operating procedures. Due to the potential for an electric shock, the area around the 480 VAC power supply to be used for the EKAR test will be posted as restricted. Only personnel trained in the operation of and safety precautions associated with the power supply will be allowed in this restricted area. At the test cells, the maximum level of the DC electrical current is expected to be approximately $2 \mathrm{~A}$. Direct contact with the electrodes will be prevented by embedding them in the soil, prior to connecting the power electrode leads to the power supplies. Power electrode leads will be fully insulated and their contacts to the electrodes covered with insulating material. The cells will be constructed of glass or nonconductive plastic to provide electrical isolation from the lab hood in which the demonstration cells will be situated. These protocols will further isolate test personnel from electrical risks. Any work inside the test cell (e.g., soil/water sampling) will be performed with the power supply off (as confirmed by voltage measurements across the power electrodes). The insulating nature of the laboratory floor will insure that no electrical current can develop (e.g., by the conductivity of the human body) from the test cell to earth ground. 
The greatest potential for hazard will occur during the period when the test cells are installed, equipped and made ready for the test. Level $\mathrm{C}$ conditions will be in effect during this period. Once the test cells have become operational, Level D as used in the laboratories of Hazen Research shall apply, i.e., laboratory coat, latex gloves, protective eyeglasses, and rubber-soled shoes for all staff members present in the laboratory.

PPE is specified at level "D”. Regular professional laboratory clothing as specified by Hazen (coat, rubber-soled shoes, and safety glasses) can be worn. Vinyl gloves, covered with chemical resistant latex gloves or equivalent shall be worn for all sampling operations. After sampling, the AC/DC converters shall be switched on again at the same setting as before.

\section{Safety Procedures}

During the entire demonstration, Hazen's standard safety protocols shall be followed. To assure that all affected personnel are aware of the appropriate procedures, a formal briefing will be held, with attendees required to sign an attendance sheet. No one will be admitted to the marked area in the vicinity of the testing apparatus during the demonstration without evidence of awareness of safety procedures. The following aspects will be strictly enforced:

- Only qualified personnel will be admitted to the lab area. For non-Hazen personnel, qualified means at least 5 years, practical experience in lab testing or chemical analysis of hazardous substances. All Hazen personnel entering the area will have received Hazen's standard hazardous materials and OSHA training. Only those personnel trained in the safe operation of the 480 VAC power supply will be allowed in the restricted (posted) area surrounding the power supply.

- Minimum 2, maximum 3 persons will be admitted simultaneously to the designated area in the laboratory.

- Exercise normal tool safety during fabrication of test cell

- The electrical power supply will not be connected until:

$>$ the test cell is fabricated,

soil electrolyte and electrodes are in place,

$>$ electrode leads are attached to electrodes,

$>$ tops of power electrodes are covered by soil and electrolyte,

$>$ electrode leads run out of the test cell to the power supply, and:

- After start-up: regular lab dress, latex gloves and rubber-soled shoes are required.

\section{9(d) Health Issues}

The two primary health concerns for staff members providing technical support to the demonstration cell operations are exposure to radioactivity and mercury. These will be addressed by minimizing contact with the contaminated soil and by monitoring exposure levels of all those present in the laboratory. Procedures for handling and blending of soil samples in preparation for loading the demonstration cells have been specified elsewhere. While 
conducting these operations, project personnel will be required to wear disposable coveralls and respirators to minimize the inhalation of airborne radionuclides or mercury vapor.

Immediately upon delivery of the contaminated soil samples from DOE, a radiation survey will be conducted of each container. If radiation is above de minimis levels, appropriate procedures will be put in place for handling and storage, including the use of personal protective equipment and radiation dosimeters to monitor worker exposure. Similarly, the areas where project personnel will be working with or exposed to unsealed containers of contaminated soils will be continuously monitored by an ambient air sampler and mercury analyzer with an alarm.

\section{Waste Management and Decontamination}

It is anticipated that the only waste generated during the Phase I activity will be the electrodes utilized in the two test cells. The electrodes will be sectioned and analyzed at the end of the test program. The electrode parts will be returned to the sponsor at the end of the test program along with the soil sample. Any unanticipated waste that is generated during the course of the test program (including decontamination) will be handled in accordance with the standard procedures in place at Hazen Research. As noted in Section 9(b) above, all contaminated materials will be returned to ORNL at the conclusion of the testing.

In the unlikely event that levels of radionuclides are present in the sample above de-minimus levels all equipment will be decontaminated at the end of the program. Decontamination will be conducted utilizing standard techniques e.g. wiping with swabs using soap and (minimal) water or dilute acid solutions. Decontamination will be verified by probe and smear analyses for radionuclides.

Any surfaces or equipment that is contaminated with mercury will be cleaned in a manner similar to that utilized for radionuclide contamination.

\section{Reports}

Routine progress reports will be made to the project manager. These will consist of weekly conference calls, monthly written progress reports, and a final report at the end of the phase 1 activity. 


\section{Schedule}

\begin{tabular}{|c|c|c|c|c|c|c|c|c|c|c|c|c|}
\hline \multirow[b]{2}{*}{ ID } & \multirow[b]{2}{*}{ Task Name } & \multirow[b]{2}{*}{ Start Date } & \multirow[b]{2}{*}{ Finish Date } & \multicolumn{2}{|c|}{ Gtr 1, 2002} & \multicolumn{3}{|c|}{ Qtr 2, 2002} & \multicolumn{3}{|c|}{ Qtr 3, 2002} & \multirow{2}{*}{\begin{tabular}{|c|} 
Qtr 4 \\
Jut
\end{tabular}} \\
\hline & & & & \begin{tabular}{|l|l|} 
Oct & Nov \\
\end{tabular} & Dec & Jan & Feb & Mar & Apr & May & Jun & \\
\hline 1 & Phase 1 & 10/1/01 & 7/1/02 & & & & & & & & & \\
\hline 2 & Task 1.1 Coordination/Planning & 10/1/01 & 3/15/02 & & & & & & & & & \\
\hline 3 & 1.1.1 Prepare for Kick-Off Meeting & 108801 & $10 / 2 \% 01$ & 娄 & & & & & & & & \\
\hline 4 & Kick-Off Meeting & $10 / 15 \% 1$ & $10 / 15 \% 01$ & $\bullet$ & & & & & & & & \\
\hline 5 & 1.1.2 NEPA Documents & $10 M / 01$ & $10 / 5,01$ & & & & & & & & & \\
\hline 6 & 1.1.3 Licenses:Permits & $10 M \pi 01$ & $10 / 5,01$ & 要 & & & & & & & & \\
\hline 7 & Task 1.1.4 Specified Document Prep \& Submission & $10 / 1,01$ & $3 / 15 / 02$ & & & & & & & & & \\
\hline 8 & 1.1.5 Requirementsicoordination for packaging, shippii & $10 / 101$ & $3 / 15 / 02$ & & & & & & & & & \\
\hline 9 & Task 1.2 Bench-Scale Work Plan & 10/26/01 & 12/21/01 & & & & & & & & & \\
\hline 10 & 1.2.1 Technology Description & $10 / 26,01$ & $10 / 29 / 01$ & 目 & & & & & & & & \\
\hline 11 & 1.2.2 Test Objectives & $10 / 26 / 01$ & $10 / 29,01$ & 具 & & & & & & & & \\
\hline 12 & 1.2.3 Experimental Design \& Procedures & $10 / 26 / 01$ & $11 / 15,01$ & I & & & & & & & & \\
\hline 13 & 1.2.4 Sample Preparation, Equipment $\&$ Materials & $10 / 26,01$ & 11,801 & 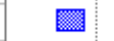 & & & & & & & & \\
\hline 14 & 1.2.5 Sampling \& Analysis Plan & $10 / 26 / 01$ & $11 / 15 / 01$ & N & & & & & & & & \\
\hline 15 & 1.2.6 Data Management & $10 / 26 / 01$ & $11 / 15 / 01$ & I. & & & & & & & & \\
\hline 16 & 1.2.7 Data Analysis \& Interpretation & $10 / 26 / 01$ & $11 / 15 / 01$ & II & & & & & & & & \\
\hline 17 & 1.2.8 Environmental, Safety $\&$ Health Plan & $10 / 26,01$ & $11 M / 01$ & ] & & & & & & & & \\
\hline 18 & 1.2.9 Waste Management $\&$ Decontamination Plan & $10 / 26,01$ & $11 M \pi 01$ & 娄 & & & & & & & & \\
\hline 19 & 1.2.10 Supplementary Material & $10 / 26 / 01$ & $11 / 15 / 01$ & 要 & & & & & & & & \\
\hline 20 & 1.2.11 Draft Work Plan Revisions as a result of $D$ & 11/12/01 & 12/21/01 & & & & & & & & & \\
\hline 21 & TPG Team Review of Draft Work Plan & $11 / 12 / 01$ & $11 / 14 / 01$ & 自 & & & & & & & & \\
\hline 22 & DOE Review of Draft Work Plan & $11 / 16 / 01$ & $12 / 14 / 01$ & & & & & & & & & \\
\hline 23 & Revision Incorporated into Final Work Plan & $12 / 14 / 01$ & $12 / 21,01$ & & 娄 & & & & & & & \\
\hline 24 & Task 1.3 Test Equip. Design, Proc., Fab \& Check-out & 10/24/01 & $12 / 20 / 01$ & & & & & & & & & \\
\hline 25 & 1.3.1 Test Equipment Design, Procurement, Fabricatior & $11 / 5 / 01$ & $11 / 30001$ & & & & & & & & & \\
\hline 26 & 1.3.2 Contaminated Soil Acquisition \& Character & 10/24/01 & $12 / 20 / 01$ & & & & & & & & & \\
\hline 27 & Sample collected by $O R$ and Received at $C O$ & $10 / 24 / 01$ & $11 / 3001$ & & & & & & & & & \\
\hline 28 & Characterize Sample & $11 / 3001$ & $12 / 20 / 01$ & & & & & & & & & \\
\hline 29 & Task 1.4 Bench-Scale Testing & 1/2/02 & 4/23/02 & & & & & & & & & \\
\hline 30 & 1.4.1 Test Protocol Development & $1 / 2 / 02$ & $1 / 29 / 02$ & & & & & & & & & \\
\hline 31 & 1.4.2 Laboratory Test Program Execution & $1 / 2 / 02$ & $4 / 23 / 02$ & & & & & & & & & \\
\hline 32 & Task 1.5 Reporting & $10 / 30 / 01$ & 7/1/02 & & & & & & & & & \\
\hline 33 & 1.5.1 Subsurface Contarninant Focus Area Mid-Year $F$ & $3 / 18 / 02$ & $3 / 20,02$ & & & & & I & & & & \\
\hline 34 & 1.5.2 Draft Topical Report & 4/23/02 & $5 / 28 / 02$ & & & & & & & & & \\
\hline 35 & Draft Developed & $4 / 23 / 02$ & $5 / 6,02$ & & & & & & & $=$ & & \\
\hline 36 & TPG Review of Draft & $5 / 6 / 02$ & $5 / 8,02$ & & & & & & & 目 & & \\
\hline 37 & DOE Review of Draft & 5,802 & $5 / 28,02$ & & & & & & & 紧 & & \\
\hline 38 & 1.5.3 Presentation of Results at NETL & $5 / 15 / 02$ & $5 / 15,02$ & & & & & & & h & & \\
\hline 39 & 1.5.4 Phase II GoNo-Go Recommendation & $5 / 22 / 02$ & $5 / 22 / 02$ & & & & & & & Y & & \\
\hline 40 & 1.5.5 Final Topical Report & $5 / 28,02$ & $7 / 1,02$ & & & & & & & & & \\
\hline 41 & 1.5.6 Annual Industry Partnerships & $10 / 30 / 01$ & $11 / 101$ & l & & & & & & & & \\
\hline
\end{tabular}




\section{Management and Staffing}

The organization chart for the phase 1 activity is shown in the following figure. The project manager for the activity is Diedre Falter with TPG Applied Technology. The experimental work will be conducted by ADA Technologies, Inc. (point of contact: John Lovell) with guidance provided by Weiss Associates (point of contact: Don Hill). The experimental equipment will be set up and operated at Hazen Research (point of contact: Rick Kenney).

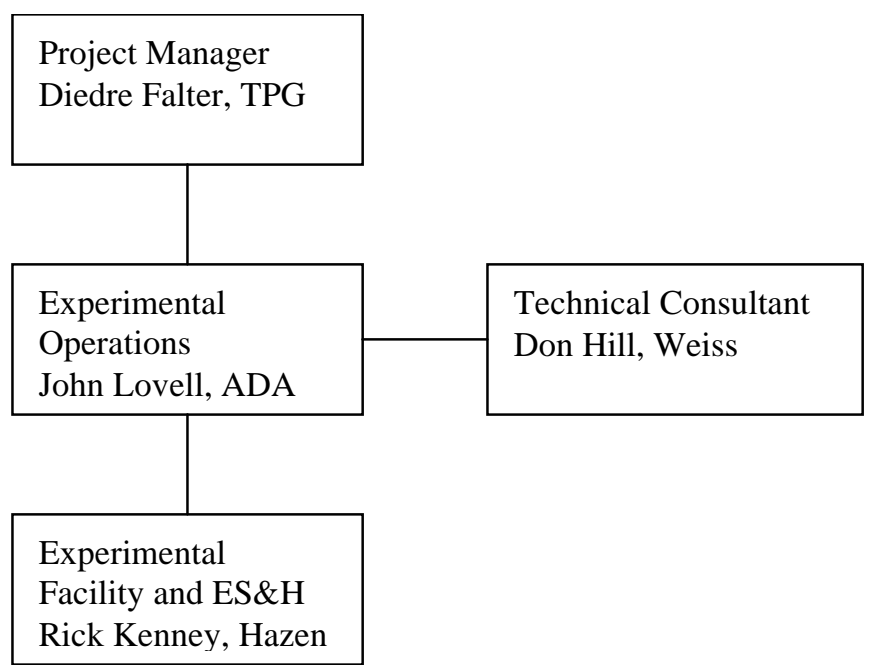

\section{Budget}

The budget for the Phase 1 activity being performed by ADA and Hazen is approximately $\$ 80,000$.

\section{REFERENCES}

Probstein, R. F., Renaud, P. C., and Shapiro, A. P., 1991, "Electroosmosis Techniques for Removing Materials from Soil", United States Patent No. 5,074,986 (filed: June 6, 1989; granted: December 24, 1991).

Döering, F., 1994, "Verfahren und Einrichtung zur Beseitigung von Schadstoffen, insbesondere im Erdbodenbereich" European Union Patent No. 0578925 A1.

Döering, F., 1996, "Verfahren zur Abtoetung von Mikrooganismen und/oder Mineralisierung von Oganischen Substanzen im Boden und im Groundwater mittens elektrischen Stromes" European Union Patent No. EP 0729796 A1.

Döering, F., 1997, "Method and Device for the Elimination of Toxic Materials from, in Particular, the Topsoil" United States Patent No. 5,595,644. 
Döering, F., 1998, "Method Related to the Sterilization of Microorganisms and/or to the Mineralization of Organic Substances Including Microbic Metabolites in a Ground Region and in the Ground Water by means of Electric Current" United States Patent No. 5,738,778. 